\title{
Fatty acid-binding protein as diagnostic marker of acute myocardial infarction in man
}

Citation for published version (APA):

Kleine, A. H. (1993). Fatty acid-binding protein as diagnostic marker of acute myocardial infarction in man. [Doctoral Thesis, Maastricht University]. Datawyse / Universitaire Pers Maastricht. https://doi.org/10.26481/dis.19930618ak

Document status and date:

Published: 01/01/1993

DOI:

10.26481/dis.19930618ak

Document Version:

Publisher's PDF, also known as Version of record

\section{Please check the document version of this publication:}

- A submitted manuscript is the version of the article upon submission and before peer-review. There can be important differences between the submitted version and the official published version of record.

People interested in the research are advised to contact the author for the final version of the publication, or visit the DOI to the publisher's website.

- The final author version and the galley proof are versions of the publication after peer review.

- The final published version features the final layout of the paper including the volume, issue and page numbers.

Link to publication

\footnotetext{
General rights rights.

- You may freely distribute the URL identifying the publication in the public portal. please follow below link for the End User Agreement:

www.umlib.nl/taverne-license

Take down policy

If you believe that this document breaches copyright please contact us at:

repository@maastrichtuniversity.nl

providing details and we will investigate your claim.
}

Copyright and moral rights for the publications made accessible in the public portal are retained by the authors and/or other copyright owners and it is a condition of accessing publications that users recognise and abide by the legal requirements associated with these

- Users may download and print one copy of any publication from the public portal for the purpose of private study or research.

- You may not further distribute the material or use it for any profit-making activity or commercial gain

If the publication is distributed under the terms of Article $25 \mathrm{fa}$ of the Dutch Copyright Act, indicated by the "Taverne" license above, 
FATTY ACID-BINDING PROTEIN AS DIAGNOSTIC MARKER OF ACUTE MYOCARDIAL INFARCTION IN MAN 


\title{
FATTY ACID-BINDING PROTEIN AS \\ DIAGNOSTIC MARKER OF ACUTE MYOCARDIAL INFARCTION IN MAN
}

\section{PROEFSCHRIFT}

\author{
ter verkrijging van de graad van doctor \\ aan de Rijksuniversiteit Limburg, te Maastricht, \\ op gezag van de Rector Magnificus, Prof.Mr. M.J. Cohen, \\ volgens het besluit van het College van Dekanen, \\ in het openbaar te verdedigen \\ op vrijdag, 18 juni 1993 om 16.00 uur
}

door

\section{ALBERT HANS KLEINE \\ geboren te Amstenrade in 1954}

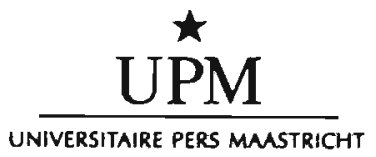


Promotores: Prof. dr. G.J. van der Vusse

Prof. dr. F.T. Bosman

Co-promotor: Dr. J.F.C. Glatz

Beoordelingscommissie:

Prof. dr. P.J. Brombacher, voorzitter

Prof. dr. J.W. Arends

Prof. dr. C.H.M.M. de Bruijn (Technische Universiteit Eindhoven)

Dr. T. Gorgels

Prof dr. W.C. Hülsmann

CIP-GEGEVENS KONINKLIJKE BIBLIOTHEEK, DEN HAAG

Kleine, Albert Hans

Fatty acid-binding protein as diagnostic marker of acute myocardial infarction in man / Albert Hans Kleine. -

Maastricht : Universitaire Pers Maastricht. - Ill.

Thesis Maastricht. - With ref. - With summary in Dutch.

ISBN 90-5278-084-6

Subject headings: fatty acid-binding protein / myocardial

infarction

Het in dit proefschrift beschreven onderzoek werd mede mogelijk gemaakt door financiële steun van het Ministerie van Economische Zaken, via de uitvoeringsorganisatie voor Technologie, Energie en Milieu (Senter). 
Ik dank jullie wel. 



\section{CONTENTS}

CHAPTER 1: General introduction y

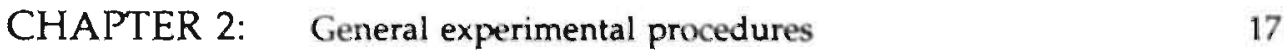

CHAPTER 3: An immunochemical assay for human heart fatty acidbinding protein

Development and Validation

CHAPTER 4: Type-specific immunodetection of human heart fatty acidbinding protein with polyclonal antibodies raised against H-FABP and synthetic peptides

CHAPTER 5: Plasma concentrations of cytoplasmatic fatty acidbinding protein (FABP) after cardiac muscle tissue damage in man

CHAPTER 6: Quantitation of myocardial infarction in man with the use of heart-type FABP plasma concentrations

CHAPTER 7: Immunohistochemical detection of very recent myocardial infarctions in man with antibodies against heart-type fatty acid-binding protein

CHAPTER 8: General discussion

Summary

Samenvatting

List of publications

Curriculum vitae 


\section{CHAPTER 1}

\section{GENERAL INTRODUCTION}

1.1. General scope p 10

1.2. Cardiac lipid transport and metabolism: role of fatty acid-binding protein $\mathrm{p} 10$

1.3. Assessment of myocardial injury p 12

1.4. Outline of thesis p 13

1.5. References p 14 


\subsection{General scope.}

Damage to myocardial tissue, e.g. as is caused by myocardial infarction, will result in the release of cytoplasmatic proteins from the cardiomyocytes into the circulation. This phenomenon is used in diagnosing myocardial tissue damage. Usually the plasma activities of the cytoplasmatic enzymes creatine kinase (CK) or lactate dehydrogenase $(\mathrm{LDH})$ are measured. Besides $\mathrm{CK}\left(\mathrm{M}_{\mathrm{r}}=88 \mathrm{kDa}\right)$ and $\mathrm{LDH}$ $\left(\mathrm{M}_{\mathrm{r}}=135 \mathrm{kDa}\right)$ the cytoplasm of cardiomyocytes also contains substantial amounts of a $s$ mall $\left(\mathrm{M}_{\mathrm{f}}=15 \mathrm{kDa}\right)$ protein called fatty acid-binding protein (FABP), to which a role in myocardial lipid metabolism is ascribed. In this thesis studies are presented concerning the suitability of measurement of FABP plasma content for diagnosing acute myocardial infarction in man.

The first chapter will give a short overview on lipid transport and metabolism in the heart, the role of FABP therein and some basic principles on ischaemia induced damage in the heart.

\subsection{LIPID TRANSPORT AND METABOLISM IN THE HEART.}

Fatty acids play an important role in cardiac energy metabolism. Their main function is to serve as fuel for $\beta$-oxidation in mitochondria and peroxisomes of cardiac myocytes. Oxidation of fatty acids, in particular the long chain ones, can supply the working heart with $60-90 \%$ of the energy necessary for electromechanical activity and other ATP requiring processes. Besides being a source of energy for the working heart, fatty acids are also used in anabolic processes like synthesis of triacylglycerols, phospholipids and cholesterol esters (Fig. 1.1.) [for recent reviews see refs. 1 and 2].

Although the heart has the capacity to store lipids, the majority of fatty acids are obtained either directly from the plasma albumin-fatty acid complex or by lipoprotein lipase catalyzed hydrolysis of circulating triacylglycerols [2]. Because hydrophobic substances like fatty acids are poorly soluble in aqueous media, such as blood plasma and intracellular fluid, they are in need of a carrier for transport through these compartments. Albumin serves as carrier for fatty acids in the bloodstream as well as in the intercellular space (interstitium). The intracellular equivalent for albumin is assumed to be a small $\left(M_{r}=15 \mathrm{kDa}\right)$ cytoplasmatic fatty acid-binding protein (FABP) (Fig. 1.1.).

Studies on intracellular lipid transporting proteins actually started with Levi and co-workers investigating the role of cellular proteins in the uptake of bilirubin into liver cells [3]. Detailed studies in the following years revealed that several families of intracellular proteins are involved in the transport of lipophilic compounds [for reviews see refs. 4 and 5]. Cytoplasmatic FABPs belong to one of these families, the so-called cytosolic $Z$ fraction. This family consists of proteins with a molecular weight in the 9-17 kDa range and with the capability to noncovalently bind various lipophilic compounds.

Ockner and co-workers were the first to describe a cellular protein capable of non-covalently binding long-chain fatty acids [6]. According to this property the protein was named fatty acid-binding protein (FABP). 


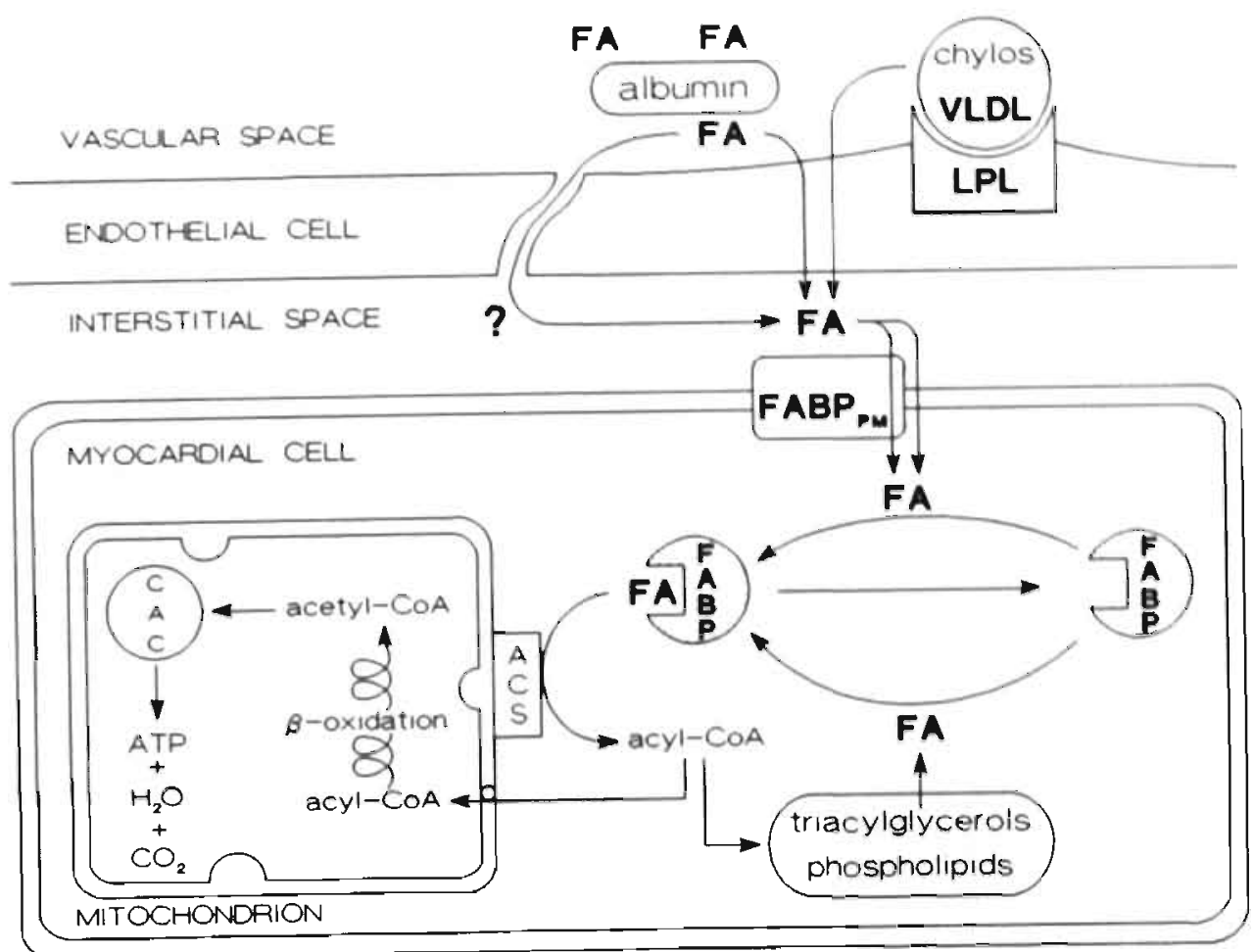

Figure 1.1. Schematic representation of the cellular metabolism of long-chain fatty acids (FA) and the possible role of cytoplasmatic fatty acid-binding protein (FABP) in the trans-cytoplasmatic transport of poorly-soluble fatty acids from the plasmalemma to their sites of esterification or oxidation. ACS, acylcoenzyme A synthetase; CAC, citric acid cycle; chylos, chylomicrons; FABP, cytoplasmatic fatty acid-binding protein; $\mathrm{FABP}_{\mathrm{pm}}$, plasmalemmal fatty acid-binding protein; LPL, lipoprotein lipase; VLDL, very-low density lipoproteins.

At least six distinct types of cytoplasmatic FABP (FABP ${ }_{c}$ ) are identified and named after the tissue of first identification, which generally is the tissue of their greatest abundance (Table 1.1) [7]. Currently the FABPs are designated as a group of 14-15 $\mathrm{kDa}$ proteins, abundantly present in the cytoplasm of various cell types, and capable of binding long-chain fatty acids and acyl-L-carnitines [for review see refs. 2,7-11]. FABPs have been found in all tissues examined, with high contents especially in those tissues showing high rates of fatty acid handling, such as liver, adipose tissue, intestine and heart. For the sake of clarity only $\mathrm{FABP}_{c}$, the cytoplasmatic fatty acid-binding protein, will be considered in this thesis, although the author is aware of the investigations on the plasmalemmal FABP (FABP pm $_{\text {) }}$ (Fig. 1.1.). $\mathrm{FABP}_{\mathrm{pm}}$ has been isolated from gut, liver, adipose tissue and heart of rats [1219] as well as been found in human hepatoma cells [20]. FABP pm $_{\text {m }}$ is fatty acidbinding protein of approximately $40 \mathrm{kDa}$ which is located in the plasmalemma, spanning both phospholipid layers, and is thought to be involved in the transport of fatty acids from the interstitium into the cytoplasm. In this thesis the name 
FABP aiways refers to the cytoplasmatic form of fatty acid-binding protein. In deviating cases the reader may find an explanation about the differing form of FABP.

Table 1.1. CYTOPLASMATIC FATTY ACID-BINDING PROTEINS (FABPS)

\begin{tabular}{|c|c|c|c|}
\hline Protein & $\begin{array}{l}\text { Currently } \\
\text { used } \\
\text { designation }\end{array}$ & $\begin{array}{l}\text { Common amino acid } \\
\text { residues }(\%)\end{array}$ & Tissue occurrence \\
\hline Heart FABP & H-FABP & 100 & $\begin{array}{l}\text { Heart, skeletal muscle, } \\
\text { kidney }\end{array}$ \\
\hline Adipocyte FABP & A-FABP & 65 & Adipose tissue \\
\hline Myelin $P_{2}$ & $P 2(=B-F A B P)$ & 61 & Peripheral nerve myelin \\
\hline Intestinal FABP & I-FABP & 32 & Small intestine \\
\hline lleal & I-LBP & 28 & Small intestine (ileum) \\
\hline Liver FABP & L-FABP (=Z-protein) & 27 & Liver, small intestine, kidney \\
\hline
\end{tabular}

Data are given for the proteins from rat, except I-LBP (lleal Lipid Binding Protein from pig) The value for rat H-FABP was set at $100 \%$.

FABP is not only found in mammalian species, but also in birds [21], flying insects [22], and in plants $[23,24]$. The members of the FABP-group are believed to be involved in the intracellular trafficking of a whole array of lipophilic compounds $[8,25]$, but specific physiological roles remain to be determined.

FABP is a true cytoplasmatic protein in the sense that it is not found in blood plasma or interstitial fluid in normal conditions. However, upon cellular injury FABP is released into the extracellular space, as was shown in cases of myocardial tissue damage due to experimental ischaemia and reperfusion in rats $[26,27]$, and due to acute myocardial infarction (AMI) in man $[28,29$, Chapter 5 this thesis] or rats [30].

\subsection{ASSESSMENT OF MYOCARDIAL INJURY.}

Under normal circumstances the oxygen supply to and demand of the myocardium are in balance. Myocardial ischaemia is the result of a reduction in coronary blood flow, as occurs for instance, in coronary artery disease. Reduction of flow through the coronary arteries results in a decline in $\mathrm{O}_{2}$-supply to the myocardial tissue, thus causing an imbalance between $\mathrm{O}_{2}$-demand and $\mathrm{O}_{2}$-supply. Because of this oxygen shortage oxidative mitochondrial metabolism will be depressed, resulting in accumulation of fatty acids and their metabolites (acyl-CoA and acyl-carnitines) and in a fall of ATP levels in cardiac cells $[31,32,33]$, both causing inhibition of cellular ion pumps. Impaired ion homeostasis and accumulation of low molecular weight degradation products leads to intracellular retention of water and, hence, to tissue oedema [34]. When the sarcolemma is stretched, due to this osmotic load, the permeability to macromolecules is increased [35]. In addition, the washout of metabolites from the tissue is impaired during this state of reduced flow. Accumulation of lactate (from anaerobic 
metabolism) and protons (from breakdown of ATP) together with an increased level of $\mathrm{CO}_{2}$ from residual respiration are readily seen, causing severe cellular acidosis. As a consequence of these detrimental events the cell membranes (sarcolemma, mitochondria, sarcoplasmatic reticulum) will sustain damage [36].

Initially, myocardial ischaemia is reversible and upon reperfusion of the myocardial tissue the cardiomyocytes will not be permanently damaged. However, when the ischaemic myocardial cell has reached "the point of no return", (acute) myocardial infarction will occur and irreversible damage will be inflicted upon the flow-deprived cell $[35,37]$. The sarcolemma will be damaged to such an extent that loss of intracellular proteins to the extracellular space and the bloodstream is observed [38].

Amongst these intracellular proteins we find high molecular weight enzymes such as lactate dehydrogenase (LDH) and creatine kinase (CK). Plasma enzyme activities of $\mathrm{LDH}$ and $\mathrm{CK}$, and of their cardiospecific iscenzymes alpha-hydroxybutyrate dehydrogenase $\left(\alpha-\mathrm{HBDH}\right.$, also called $\left.\mathrm{LDH}_{1}\right)$ and creatine kinase $\mathrm{MB}(\mathrm{CK}$ $\mathrm{MB})$, respectively, are currently used for both the assessment of acute myocardial infarction and the estimation of the extent of myocardial injury in patients with ischaemic heart disease $[39,40]$.

Myoglobin, the oxygen-carrying protein inside muscle cells, has been introduced as a plasma marker for early (within 3 hours after the first symptoms of myocardial infarction) indexation and quantification of acute myocardial infarction [41-48]. Because H-FABP and myoglobin share common features - both are cytoplasmatic non-enzymatic proteins of comparable molecular weight $\left(\mathrm{M}_{\mathrm{r}}=15 \mathrm{kDa}\right.$ and $17.2 \mathrm{kDa}$, respectively) - H-FABP might also be a suitable marker for early indexation and possible quantification of acute myocardial infarction.

\subsection{OUTLINE OF THESIS.}

The aim of the present thesis is to assess whether loss of FABP from the human heart into the circulation under pathophysiological conditions makes it possible to use the plasma FABP content for qualitative and quantitative assessment of AMI in man. To better define the suitability of the plasma FABP content for the assessment of AMI, a comparison with other cytoplasmatic proteins which are currently used for assessment of myocardial infarction is made.

One of the first issues we had to address was the development of a reliable assay system for the detection of H-FABP in human plasma. Because H-FABP is a non-enzymatic protein, a direct quantitative measurement of enzymatic activity in plasma is not possible. Direct quantitative measurement of plasma H-FABP content through its functional capacity of binding fatty acids is also excluded because of the abundant presence of albumin in plasma. Because other quantitative measurements require preceding extraction of H-FABP from the plasma, with the possible intro-duction of inaccuracies, the decision was made to develop a quantitative immunochemical assay to monitor H-FABP in human blood.

The basis of an immunoassay is the antigen, in this case human H-FABP. First of all the pure antigen is required to evoke production of antibodies against the antigen, after the latter is presented to the immune system of the test animal. The 
pure antigen is also needed for calibration of the immunoassay. The isolation and purification of $\mathrm{H}-\mathrm{FABP}$ from human heart tissue, and the production of antibodies against human H-FABP, using the purified protein as antigen, are described in Chapter 2. Finally, the development and validation of the immunoassay are described in Chapter 3.

The synthesis of oligo-peptides, corresponding with different antigenic parts of the human H-FABP molecule, is described in Chapter 2 section 5. These synthetic peptides were used for development of type-specific antibodies to human H-FABP (Chapter 2 section 6), which were used in the experiments described in Chapter 4.

In order to test the hypothesis that H-FABP measurements in the bloodstream after AMI or ischaemia in the myocardium will offer a reliable qualitative index of loss of cellular integrity, we collected blood samples from patients who were admitted to the coronary care unit of the hospital with suspicion of AMI. The HFABP concentrations in these blood samples were determined using the immunoassay described in Chapter 3 . The reader may find the description of the methods applied for and the results obtained from these investigations in Chapter 5.

The total myocardial tissue damage due to an AMI is usually calculated from the total release of cytoplasmatic enzymes (CK-MB, $\alpha-\mathrm{HBDH}$ ) into the circulation. Whether or not the total release of H-FABP is also suitable for quantitation of myocardial tissue damage was investigated in a large group of patients with AMI. The results were compared with results from other parameters which were measured in the same group of patients and are generally used for calculation of total myocardial tissue damage due to an AMI. The results of these investigations are described in Chapter 6.

The appearance of H-FABP in the bloodstream, released from ischaemic or infarcted myocardium, has to be accompanied by diminished levels of H-FABP in cardiomyocytes in the ischaemic or infarcted region of the heart. We therefore performed macroscopic enzyme-histochemical, and microscopic histochemical and immunohistochemical experiments (see Chapter 7) on human myocardial tissue sections that included areas that had suffered from ischaemia and/or infarction. In the immunohistochemical experiments the tissue sections were stained with antibodies against H-FABP. The results were compared with a conventional microscopic histochemical and a macroscopic enzyme-histochemical technique to delineate the usefulness of anti-FABP staining in assessing acute myocardial infarction in the clinical setting.

In the final Chapter 8 the results of the various investigations in this thesis are compared, discussed, and summarized.

\subsection{REFERENCES.}

1. Van der Vusse GJ, Glatz JFC, Stam HCG: Myocardial fatty acid homeostasis. Mol Cell Biochem 88: 1-6, 1989.

2. Van der Vusse GJ, Glatz JFC, Stam HCG, Reneman RS: Fatty acid homeostasis in the normoxic and ischemic heart. Physiol Rev 72: 881-940, 1992.

3. Levi AJ. Gatmaitan Z, Arias IM: Two hepatic cytoplasmic protein fractions, $Y$ and $Z$, and their possible role in the hepatic uptake of bilirubin, sulfobromophtalein, and other anions. I Clin Invest 48: $2156-2167,1969$. 
4. Bernier 1, Jolles P. A survey on cytosolic non-enzymic proteins involved in the metabolism of lipophilic compounds: from organic anion binders to new protein families. Biochimie 69: $1127=1152$. 1987.

5. Ockner RK: Historic overview of studies on fatty acid-binding proteins. Mol Cell Biochem 98: 3-9, 1990.

6. Ockner RK, Manning JA, Poppenhausen. RB, Ho WKL: A binding protein for fatty acids in cytosol of intestinal mucosa, liver, myocardium, and other tissues. Science 177: 56-58, 1972.

7. Glatz JFC, Van der Vusse G]: Nomenclature of fatty acid-binding proteins. Mol' Cell' Biochem 98 231-235, 1990

8. Sweetser DA, Heuckeroth RO, Gordon II: The metabolic significance of manmalian fatty acidbinding proteins: Abundant proteins in search for a function. Annu Rev Nutr $7.337-359,1987$.

9. Bass NM: The cellular fatty acid binding proteins: Aspects of structure, regulation, and function. Int Reo Cytol 111: 143-184, 1988.

10. Clarke SD. Armstrong MK: Cellular lipid binding proteins: expression, function, and nutritional regulation. FASEB / 3: 2480-2487, 1989.

11. Veerkamp JH, Peeters RA, Matman RGHI: Structural and functional featuresi of different types of cytoplasmic fatty acid-binding proteins. Biochim Biophys Acta 1081: 1-24, 1991.

12. Stremmel $\mathbf{W}$, Lotz $G$, Strohmeyer G, Berk PD: Identification, isolation, and partial characterization of a fatty acid binding protein from jejunal microvillous membranes. / Clin Invest 75: 1026-1076. 1985.

13. Stremmel $\mathbf{W}$. Theilmann L: Selective inhibition of long-chain fatty acid uptake in short-term cultured rat hepatocytes by an antibody to the rat liver plasma membrane fatty acid-binding protein. Biochim Biophys Acta 877: 191-197, 1986.

14. Stremmel W, Strohmeyer G, Berk PD: Hepatocellular uptake of oleate is energy dependent,sodium linked, and inhibited by an antibody to a hepatocyte plasma membrane fatty adid binding, proteir. Proc Natl Acad Sci, USA 83: 3584-3588, 1986.

15. Potter BJ, Stump D, Schwieterman W, Sorrentino D, Jacobs LN, Kiang C-L, Rand JH, Berk PD; Isolation and partial characterization of plasma membrane fatty acid-binding protein from myocardium and adipose tissue and their relationship to analogous proteins in liver and gut. Biochem Biophys Res Comm 148: 1370-1376, 1987.

16. Fujii S, Kawaguchi $\mathrm{H}$, Yasuda $\mathrm{H}$ : Purification of high affinity fatty acid receptors in rat myocardial sarcolemmal membranes. Lipids 22: 544-546, 1987.

17. Schwieterman W, Sorrentino D, Potter BJ, Rand J, Kiang C-L, Stump D, Berk PD: Uptake of oleate by isolated rat adipocytes is mediated by a $40-\mathrm{kDa}$ plasma membrane fatty acid binding protein closely related to that in liver and gut. Proc Natl Acad Sci USA 85: 359-363, 1988.

18. Stremmel $\mathbf{W}$ : Fatty acid uptake by isolated rat heart myocytes represents a carrier-mediated transport process. / Clin Invest 81: 844-852, 1988.

19. Stremmel $\mathbf{W}$ : Uptake of fatty acids by jejunal mucosal cells is mediated by a fatty acid binding membrane protein. / Clin Invest 82: 2001-2010, 1988.

20. Stremmel $\mathbf{W}$, Diede HE: Fatty acid uptake by human hepatoma cell lines represents a carriermediated uptake process. Biochim Biophys Acto 1013: 218-222, 1989.

21. Collins DM, Hargis PS: Distribution of fatty acid binding proteins in tissues and plasma of Gallus domesticus. Comp Biochem Physiol 92B: 283-289, 1989.

22. Haunerland NH, Chisholm JM: Fatty acid binding protein in flight muscle of the locust, Schistocerca gregaria. Biochim Biophys Acta 1047: 233-238, 1990.

23. Kader JC: Lipid-binding proteins in plants. Chem Phys Lipids 38: 51-62, 1985.

24. Arondel V, Vergnolle C, Tchang F, Kader JC: Bifunctional lipid-transfer/fatty acid-binding proteins in plants. Mol Cell Biochem 98: 49-56, 1990.

25. Bass NM: Function and regulation of hepatic and intestinal fatty acid-binding protein. Chem Phys Lipids 38: 95-114, 1985

26. Glatz JFC, Van der Vusse GJ: Intracellular transport of lipids. Mol Cell Biochem 88: 37-44, 1989.

27. Glatz JFC, van Bilsen M, Paulussen RJA, Veerkamp JH, Van der Vusse GJ, Reneman RS: Release of fatty acid-binding protein from isolated rat heart subjected to ischemia and reperfusion or to the calcium paradox. Biochim Biophys Acta 961: 148-152, 1988.

28. Knowlton AA, Burrier RE, Brecher P: Rabbit heart fatty acid-binding protein: Isolation, characterization, and application of a monoclonal antibody. Circ Res 65: 981-998, 1989. 
29. Tanaka T, Hirota $Y$, Sohmiya K-i, Nishimura S, Kawamura K: Serum and urinary human heart fatty acid-binding protein in acute myocardial infarction. Clin Biochem 24: 195-201, 1991.

30. Knowlton AA, Apstein CS, Saouf $R$, Brecher $P$ : Leakage of heart fatty acid binding protein with ischemia and reperfusion in the rat. I Mol Cell Cardiol 21: 577-583, 1989.

31. Kubler W, Spieckermann PG: Regulation of glycolysis in the ischemic and the anoxic myocardium. I Mol Cell Cardiol 1: 351-377, 1970.

32. Hearse DJ: Oxygen deprivation and early myocardial contractile failure: $A$ reassessment of the possible role of adenosine triphosphate. Am / Cardiol 44: 1115-1121, 1979.

33. Van der Vusse GJ, Roemen THM, Prinzen FW, Coumans WA, Reneman RS: Uptake and tissue content of fatty acids in dog myocardium under normoxic and ischemic conditions. Circ Res 50: 538- 546, 1982.

34. McKnight ADC, Leaf A Regulation of cell volume. Physiol Rev 57: 510-573, 1977.

35. Ople L.H In: The heart, Grune \& Stratton Inc, Orlando, USA, pp 351-371, 1986.

36. Jennings RB, Reimer KA: Lethal myocardial ischemic injury. Am / Path 102: 241-255, 1981

37. Greve $G$ : Ultrastructural findings in hearts with regional ischaemia, Virchows Archiv $A$ Pathol Anat 417: 1-3, 1990.

38. Kupper W, Bleifeld W: Serum enzyme changes in patients with cardiac diseases. In: Advances in clinical enzymology. E. Schmidt, F.W. Schmidt, I. Trautshold, R. Friedel (Eds), Basel, S. Karger, pp $107 \cdot 123,1979$.

39. Willems GM, Muljtiens AMM, Lambi FHH, Hermens WTh: Estimation of circulatory parameters in patients with acute myocardial infarction. Significance for calculation of enzymatic infaret size. Cardiovasc Res 13: 578-587, 1979.

40. Van der Veen FH, Visser R, Willems GM, Kop-Klaassen B, Hermens WTh: Mycrardial enzyme depletion in infarcted human hearts: infarct size and equivalent tissue mass. Cardiouasc Res 22: 611$619,1988$.

41. Stone MJ, Waterman MR, Harimoto D, Murray G, Wilson N, Platt MR, Blomqvist G, Willerson JT: Serum myoglobin level as diagnostic test in patients with acute myocardial infarction. $\mathrm{Br} \mathrm{Heart} /$ 39: 375-380, 1977.

42. Varki AP, Roby DS, Watts $\mathrm{H}$, Zatuchni J: Serum myoglobin in acute myocardial infarction: A clinical study and review of the literature. Am Heart J 96: 680-688, 1978.

43. Drexel H, Dworzak E, Kirchmair W, Miz MM, Puschendorf B, Diensti F: Myoglobinemia in the rarly phase of acute myocardial infarction. Am Heart / 105: 642-651, 1983.

44. McComb JM, McMaster EA, MacKenzie G, Adgey AAJ: Myoglobin and creatine kinase in acute myocardial infarction. Br Heart / 51: 189-194, 1984.

45. Isakov A, Shapira 1 , Burke $M$, Almog C: Serum myoglobin levels in patients with ischemic myocardial insult. Arch Intern Med 148: 1762-1765, 1988.

46. Ellis AK, Saran BR: Kinetics of myoglobin release and prediction of myocardial depletion after coronary artery reperfusion. Circulation 80:676-683, 1989.

47. Ohman EM, Casey C, Bengtson JR, Pryor D, Tormey W, Horgan JH: Early detection of acute myocardial infarction: additional diagnostic information from serum concentrations of myoglobin in patients without ST elevation. Br Heart / 63: 335-338, 1990.

48. Dressen-Kletter MF, Amelink GJ, Bär PR, van Gijn J: Myoglobin is a sensitive marker of increased muscle membrane vulnerability. I Neurol 237: 234-238, 1990. 


\section{CHAPTER 2}

\section{GENERAL EXPERIMENTAL PROCEDURES}

2.1. Introduction $\mathrm{p} 17$

2.2. Purification of H-FABP, method A p 19

2.3. Purification of H-FABP, method B p 20

2.4. Determination of H-FABP concentrations p 23

2.5. Synthesis of peptide sequences from the H-FABP molecule p 24

2.6. Immunization of test animals and raising of polyclonal antibodies $p 27$

2.7. Purification of polyclonal rabbit antibodies p 27

2.8. Fatty acid-binding studies with H-FABP p 27

2.9. Immuno- and enzyme-histochemistry p 29

2.10. Measurement of the myoglobin plasma concentration p 30

2.11. Measurement of CK-MB and $\alpha-\mathrm{HBDH}$ activity p 30

2.12. Source of materials p 31

2.13. References p 32 


\subsection{INTRODUCTION.}

As stated in the general introduction we decided to use an immunochemical assay for the detection of H-FABP in human plasma and an immunohistochemical assay for the detection of losses of H-FABP from human myocardial tissue. In this chapter the general experimental procedures, required for the development of an immunochemical assay for H-FABP are described in detail. We started out with the isolation and purification of H-FABP from human myocardial tissue, the procedures being described in sections 2.2. and 2.3. The resulting pure human H-FABP was used for production of polyclonal antibodies in several test animals of different species (section 2.6.). The purified H-FABP was also used in the purification of antisera (section 2.7.), in binding studies (section 2.8.), and as a calibration protein in the immunoassay (see Chapter 4 ). To this end several spectrophoto-metrical assays for determination of protein concentrations in solutions were tested for their suitability to measure specifically the H-FABP concentration (section 2.4.).

Since the various known FABP types share identical amino-acid sequences in varying degrees, we also attempted to raise type-specific antibodies against human H-FABP. To this end four oligo-peptides of 15-20 amino acids each and corresponding with different antigenic parts of the human H-FABP molecule were synthesized (section 2.5.). Polyclonal antibodies against these synthetic peptides were raised in mice and rabbits (section 2.6.), and used in the experiments described in Chapter 4.

The produced and purified antibodies (section 2.7.) directed against the native $\mathrm{H}$-FABP molecule as well as those against its antigenic parts - the synthetic peptides - were used as components of an immunochemical assay for human $\mathrm{H}$ FABP (Chapter 4). In addition, the rabbit antibodies against H-FABP were used for microscopic immunohistochemical experiments on human myocardial and nonmyocardial tissue sections (section 2.9. and Chapter 7).

Results of the experiments with the immunochemical assay for human H-FABP were compared with measurements of myoglobin contents in plasma and tissue samples (section 2.10) and with measurements of the activities of cytoplasmatic enzymes (CK-MB and $\alpha-\mathrm{HBDH}$ ) in plasma samples (see Chapter 5).

For the sake of legibility manufacturers of the used equipment and chemicals are listed separately in section 2.12 .

\section{Purification of humaN H-FABP.}

H-FABP was isolated from human cardiac tissue obtained during post-mortem examination and stored at $-20^{\circ} \mathrm{C}$ until further use. To avoid unwanted effects of autolysis, if any, only tissue samples obtained within 12 hours post-mortem were used. Isolation and purification procedures were modified after Glatz et al. [1]. 


\subsection{Purification Method A.}

Homogenisation of human heart tissue.

After removal of visible fat from the pieces of human heart tissue a homogenate $(25 \%, w / v)$ was prepared in ice-cold buffer, consisting of $10 \mathrm{mM}$ Tris$\mathrm{HCl}$ ( $\mathrm{pH} \mathrm{8.0),} 150 \mathrm{mM} \mathrm{KCl}$ and $1 \mathrm{mM}$ dithiothreitol, using an ultra Turrax homogenizer. Centrifugation of the homogenate was performed in two steps. In the first step the homogenate was centrifuged at $3,000 \times \mathrm{g}$ and $4^{\circ} \mathrm{C}$ for 10 minutes, followed by removal of floating fat by filtration of the supernatant through coarse gauze. In the second step the supernatant from the first step (Sup.) was centrifuged at $105,000 \times \mathrm{g}$ and $4^{\circ} \mathrm{C}$ for 90 minutes. If present residual floating fat was removed by aforesaid filtration. The final supernatant $\left(S_{105}\right)$, containing the cytosolic proteins, was concentrated by ultra-filtration using a Diaflo YM5 membrane (cut off $=5.0 \mathrm{kDa}$ ).

\section{Gel permeation chromatography.}

The Sup ${ }_{105}$ was applied to a column of Sephacryl S200-SF $(2.6 \times 90 \mathrm{~cm})$ equilibrated with homogenization buffer. Elution of proteins, at a flow rate of 3 $\mathrm{ml} / \mathrm{min}$, was monitored spectrophotometrically at $280 \mathrm{~nm}$, using an UV-monitor (equipped with a flow cell) which was connected to a flatbed recorder. Fractions of $3 \mathrm{~min}(10 \mathrm{ml})$ were collected with a fraction collector. H-FABP was identified in the low molecular weight fractions (usually \#100\#150, which contain proteins of approximately 10-60 kDa), with the use of the Lipidex 1000 assay [2]. Relevant fractions containing H-FABP (Fig. 2.1.) were pooled, concentrated, and dialysed overnight at $4^{\circ} \mathrm{C}$ against $5 \mathrm{mM}$ Tris- $\mathrm{HCl}(\mathrm{pH} 8.0)$.

\section{Anion-exchange chromatography.}

The concentrated and dialysed H-FABP containing fractions were applied to a column of Sepharose-Q fast flow $(1.6 \times 15 \mathrm{~cm})$ equilibrated with dialysis-buffer. $\mathrm{H}-$ FABP was collected after stepwise gradient-elution $(0-30 \mathrm{mM} \mathrm{NaCl}$ in $5 \mathrm{mM}$ Tris$\mathrm{HCL}, \mathrm{pH} 8.0$ ). Finally, the protein was dialysed against $10 \mathrm{mM}$ potassium phosphate ( $\mathrm{pH} \mathrm{7.4),} \mathrm{containing} 150 \mathrm{mM} \mathrm{NaCl}$, and stored in aliquots at $-20^{\circ} \mathrm{C}$.

Although the purification method described above gave satisfactory results, the method was slightly changed during the course of the investigations. In short, we changed the size of the column and the respective buffers for homogenisation, anion exchange chromatography, and storage conditions [3]. The advantage of the revised technique is that only two different buffers are needed for the entire purification protocol, and that the $\mathrm{pH}$ can be held at a more physiological value of 7.0. Furthermore, the yield of H-FABP was higher with the revised technique (Method B), which is described in section 2.3. 


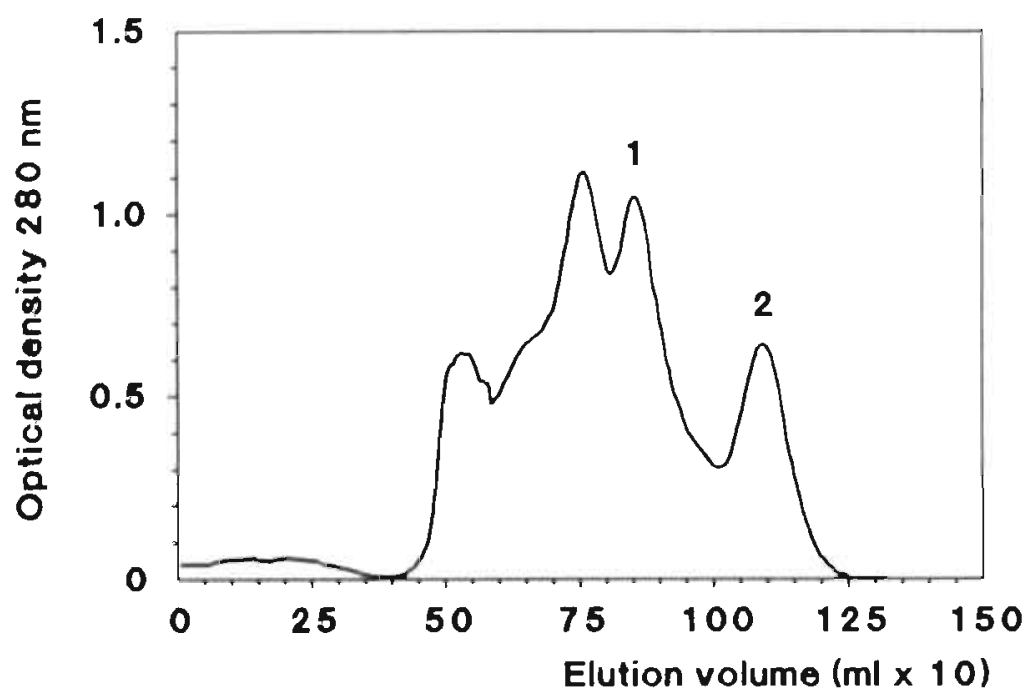

Pigure 2.1. Typical elution pattern of gel permeation chromatography on a Sephactyl 200 superfine (S200-SF) column of the cytosolic protein fraction obtained from a homogenate of human myocardium (see section 2.2. and 2.3. for details). The low molecular weight fraction (peak \#2, mainly H-FABP and myoglobin) has clearly been separated from the higher molecular weight fractions (cf. peak \#1, mainly albumin).

\subsection{Purification Method B.}

\section{Homogenisation of human heart tissue.}

All steps of the purification procedure were carried out at $4^{\circ} \mathrm{C}$. Human heart tissue, from which visible fat was removed, was homogenised $(20 \%, w / v)$ in phosphate buffered saline (PBS), containing $10 \mathrm{mM} \beta$-mercaptoethanol, with the use of an ultra Turrax homogenizer. After centrifugation of the homogenate at $2,600 \times \mathrm{g}$ for 10 minutes the pellet was resuspended in the original volume of buffer and centrifuged again for 10 minutes at $2,600 \times \mathrm{g}$. The combined supernatants $\left(\right.$ Sup $\left._{2.6}\right)$ were subsequently centrifuged at $105,000 \times \mathrm{g}$ for $90 \mathrm{~min}$. The resulting Sup $_{105}$ was concentrated by ultra-filtration using a Diaflo YM-5 membrane.

\section{Gel permeation chromatography.}

Gel permeation chromatography was carried out on a Sephacryl S-200 SF column $(5 \times 90 \mathrm{~cm})$ equilibrated with homogenisation buffer at a flow rate of 3 $\mathrm{ml} / \mathrm{min}$. The eluate was monitored for protein at $280 \mathrm{~nm}$ using an UV-monitor (equipped with a flow cell) which was connected to a flatbed recorder. Fractions of $3 \mathrm{~min}(9 \mathrm{ml})$ were collected with a fraction collector. The low molecular weight 
fractions (usually fractions \#100-\#150) were pooled, concentrated and dialysed

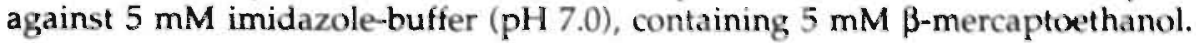

\section{Anion-exchange chromatography.}

The dialysed and concentrated low molecular weight fractions were applied to a Sepharose $\mathrm{Q}$ fast-flow column $(1.6 \times 15 \mathrm{~cm})$ and eluted at a flow rate of $2 \mathrm{ml}$ / min. A $5 \mathrm{mM}$ imidazole buffer ( $\mathrm{pH} 7.0$ ), containing $5 \mathrm{mM} \mathrm{B}$-mercaptoethanol was used as starting buffer. Elution of protein was monitored at $280 \mathrm{~nm}$ with an UVmonitor. Fractions of $5 \mathrm{~min}$ were collected with a fraction collector. H-FABP was eluted using a $300 \mathrm{ml}$ linear gradient of $0-20 \mathrm{mM} \mathrm{NaCl}$ in starting buffer. Thereafter residual bound protein was eluted with a $5 \mathrm{mM}$ imidazole buffer $(\mathrm{pH}$ 7.0), containing $5 \mathrm{mM} \beta$-mercaptoethanol and $2 \mathrm{M} \mathrm{NaCl}$ (see Figure 2.2.). The fractions containing H-FABP were identified by the Lipidex 1000 assay [2] and subsequently collected, concentrated and dialysed against PBS.

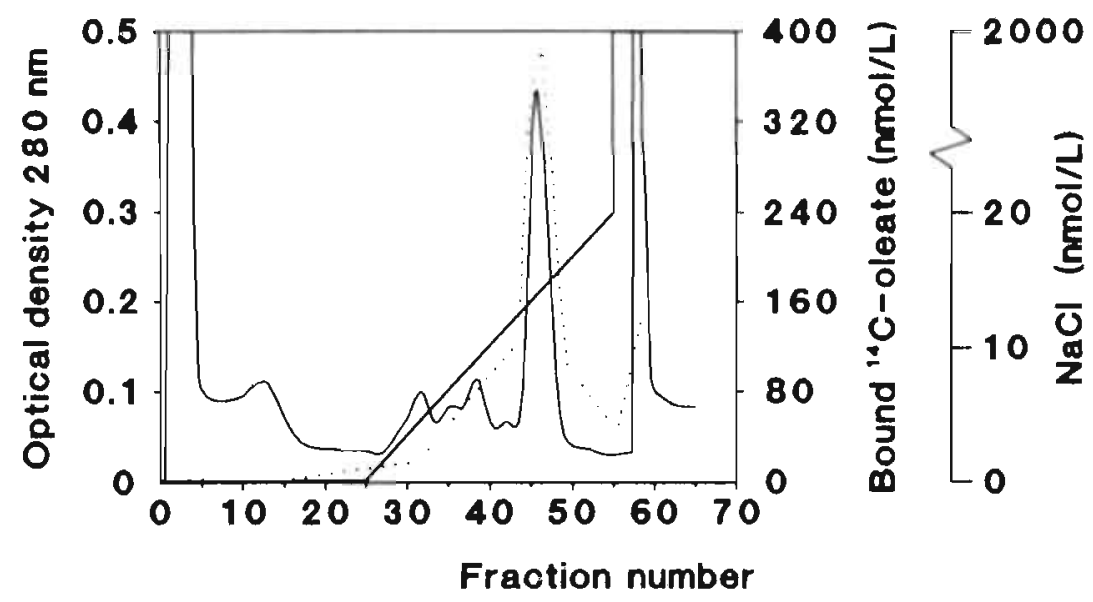

Figure 2.2. Anion-exchange chromatography on a sepharose $Q$ fast flow column $(1.6 \times 15 \mathrm{~cm})$ of the low molecular weight fraction obtained by gel permeation chromatography (see Fig. 2.1.). H-FABP was eluted with a linear gradient of $\mathrm{NaCl}$ (bold line) in starting buffer. Elution was monitored at $\mathrm{A}_{200}$ (solid line) for protein. Fatty acid-binding was measured with the Lipidex assay using ${ }^{14} \mathrm{C}$-oleate (broken line).

\section{Gel permeation chromatography on a Superdex-75 column.}

To detect any impurities a small portion of the H-FABP fraction of the anionexchange chromatography was applied to a Superdex-75 gel permeation chromatography column $(2.6 \times 60 \mathrm{~cm})$ equilibrated with PBS at a flow rate of $2 \mathrm{ml} / \mathrm{min}$. The eluate was monitored for protein at $280 \mathrm{~nm}$ using an UV-monitor (see Figure 2.3.). Fractions of 5 min were collected with a fraction collector. Purity of FABP was assessed by sodium dodecyl sulphate polyacrylamide-gel electrophoresis (SDSPAGE) and isoelectric focusing (IEF) (Fig. 2.4.). The H-FABP sample obtained from the anion-exchange chromatography step showed one band in the $15 \mathrm{kDa}$ range in 
SDS-PAGE, while IEF of the same sample showed 2 bands with isoelectric points at 5.2 and 5.4. The elution pattern of the gel permeation chromatography on Superdex-75 (Fig. 2.3.) of the aforesaid H-FABP sample showed only one symmetrical peak. A sample from this peak revealed one band in SDS-PAGE as well as in IEF (Fig. 2.4.), thus demonstrating the purity of the H-FABP sample.

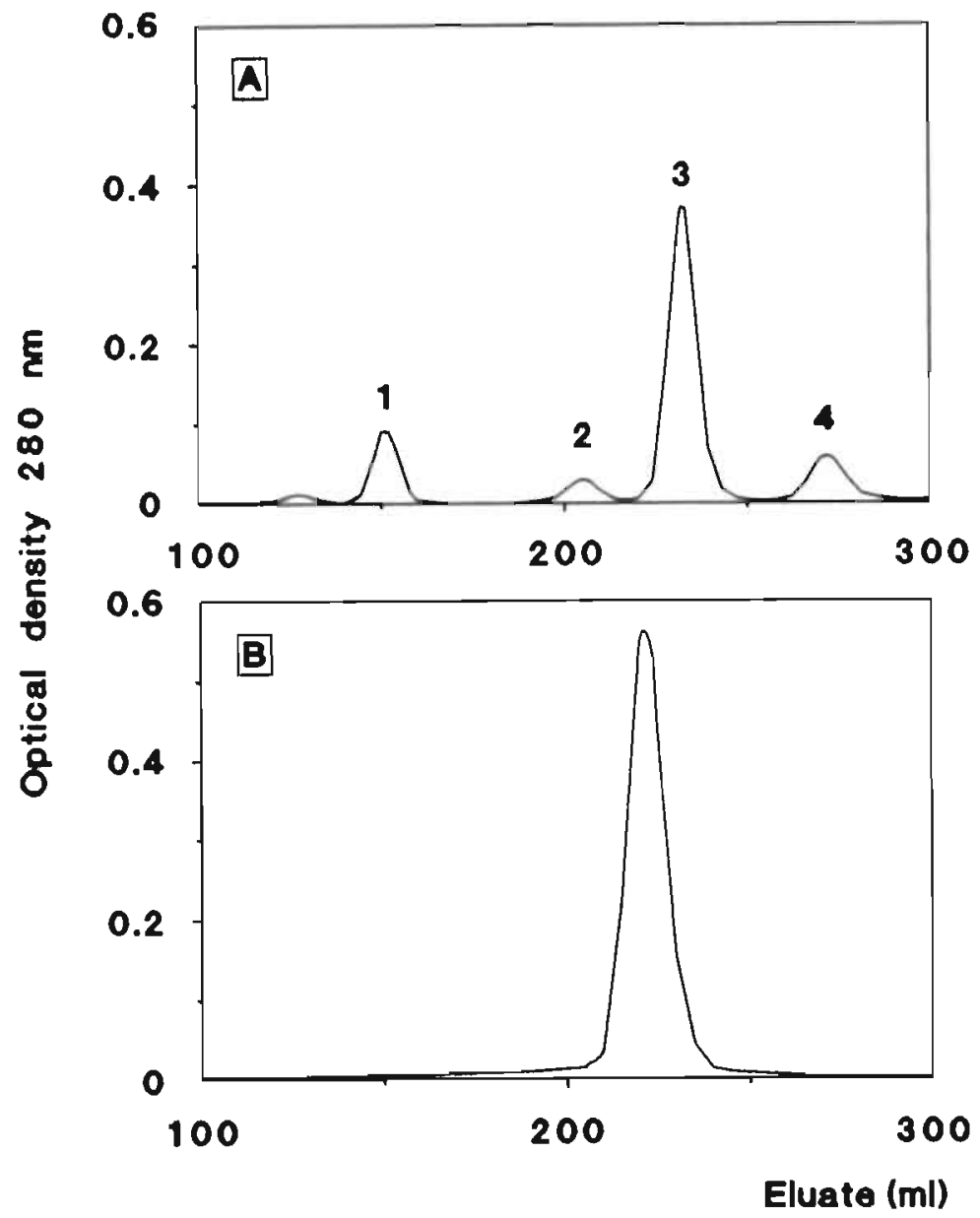

Figure 2.3. Gel permeation chromatography on a Superdex-75 column $(2.6 \times 60 \mathrm{~cm})$. Run A with molecular weight calibration proteins: 1) bovine serum albumin $67 \mathrm{kDa}, 2$ ) trypsin inhibitor $20.1 \mathrm{kDa}, 3$ ) cytochrome $(12.5 \mathrm{kDa}, 4)$ aprotinine $6.5 \mathrm{kDa}$. Run $\mathrm{B}$ with $\mathrm{H}$-FABP previously purified by anionexchange chromatography. 


\section{SDS-PAGE}

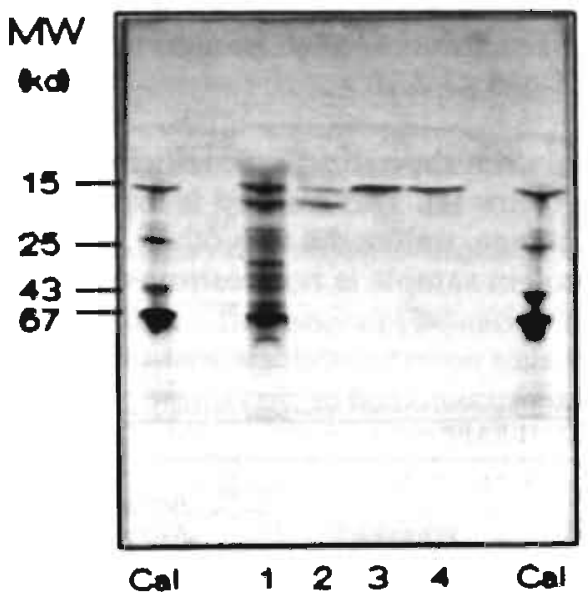

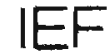

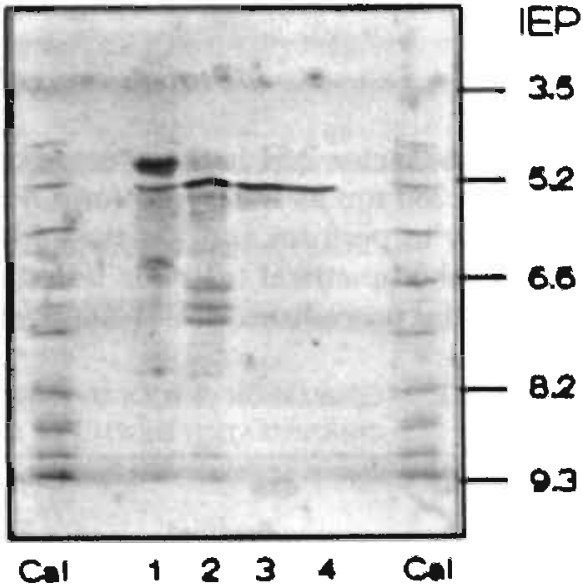

Figure 2.4. SDS polyacrylamide gel electrophoresis (SDS-PAGE) and isoelectric focusing (IEF) illustrating the chromatographical steps of the purification described in section 2.3. Lane 1: sample after homogenisation, lane 2: sample after gel permeation chromatography on S-200 SF, lane 3: Sample after anion-exchange chromatography, lane 4: Sample after gel permeation chromatography on superdex-75. CAL lane: Calibration proteins for SDS-PAGE and IEF. Calibration proteins for SDS-PAGE were: bovine serum albumin $\left(M_{r}=67 \mathrm{kDa}\right)$, ovalbumin $\left(M_{\mathrm{r}}=43 \mathrm{kDa}\right)$, chymotrypsinogen $A\left(M_{\mathrm{r}}=25 \mathrm{kDa}\right)$ and purified human H-FABP $\left(\mathrm{M}_{\mathrm{r}}=15 \mathrm{kDa}\right)$. Calibration proteins for $\mathrm{IEF}$ (with the isoelectric points in parentheses) were: amyloglucosidase (3.50), soybean trypsin inhibitor (4.55), $\beta$-lactoglobulin $A(5.20)$, bovine carbonic anhydrase $B(5.85)$, human carbonic anhydrase $B(6.55)$, horse myoglobin (6.85 and 7.35 ), lentil lectin (8.15, 8.45 and 8.65$)$ and trypsinogen (9.30).

\subsection{DETERMINATION OF H-FABP CONCENTRATIONS.}

The methods of Withaker and Granum [4], Lowry et al.[5] and Bradford [6] were tested for their suitability to measure H-FABP concentrations in solutions, using different samples of purified human H-FABP. The validity of the different spectrophotometrical assays was compared with results from amino-acid analyses of the same samples (Table 2.1.). To this end the protein samples were hydrolysed with $6 \mathrm{M} \mathrm{HCl}$ for 18 hours at $110^{\circ} \mathrm{C}$. Subsequently, amino acid analysis was carried out using standard HPLC-techniques according to Van Eijk et al. [7]. Comparison of the different assays showed that the method of Lowry overestimated the H-FABP concentration in all three samples, while the method of Bradford underestimated the concentration in one of the three samples and overestimated the concentration in the other two samples. The method of Whitaker and Granum seemed to serve our purposes best for it underestimated the concentration in all samples by about $10 \%$. Therefore this method was used in all experiments for determining H-FABP concentrations.

The method of Withaker and Granum makes use of the differences in absorbance of a protein solution when measured at two different wavelengths (235 
and $280 \mathrm{~nm}$ ). The protein concentration $(\mathrm{mg} / \mathrm{ml}$ ) can subsequently be calculated by using the equation

$$
\text { Protein concentration }=\left(A_{235}-A_{280}\right) / 2.51
$$

where the factor 2.51 is the average difference between the extinction coefficient at 235 and $280 \mathrm{~nm}$ as measured for a number of proteins [4]. This method is rapid and easy to perform and has the additional advantage, unlike the two other spectrophotometrical methods tested, that the protein sample is not destroyed during the procedure.

Table 2.1. COMPARISON OF POUR DIFFERENT METHODS FOR DETERMINATION OF THE PROTEIN CONCENTRATION (MG/ML) OF PURIFIED HUMAN H-FABP.

\begin{tabular}{cllll}
\hline Sample & Bradford & Lowry & Whitaker & \multicolumn{1}{c}{$\begin{array}{c}\text { Amino- acid } \\
\text { Analysis }\end{array}$} \\
\hline \multirow{2}{*}{ A $^{2}$} & 0.18 & 0.24 & 0.16 & 0.19 \\
& $(=95 \%)$ & $(=126 \%)$ & $(=84 \%)$ & $(=100 \%)$ \\
2 & 0.38 & 0.53 & 0.31 & 0.33 \\
3 & $(=115 \%)$ & $(=160 \%)$ & $(=94 \%)$ & $(=100 \%)$ \\
& 0.27 & 0.35 & 0.21 & 0.23 \\
Mean \pm SD & $(=117 \%)$ & $(=152 \%)$ & $(=91 \%)$ & $(=100 \%)$ \\
\hline
\end{tabular}

- Samples 1-3 were from 3 purification procedures.

' Bradford [6]; ${ }^{2}$ Lowry et al. [5]; ${ }^{3}$ Whitaker et al. [4]; " Van Eijk et al. [7].

\subsection{SYNTHESIS OF PEPTIDE SEQUENCES FROM THE H-FABP MOLECULE.}

In order to develop type-specific antibodies to human H-FABP an antigenic index [8,9] was computed to identify highly antigenic regions on the human $\mathrm{H}$ FABP molecule. Characteristic parts within these antigenic regions were synthesized and conjugates of each of these synthetic peptides and a carrier protein (Keyhole Limpet Haemocyanin) were used for inoculation of rabbits and mice.

Based on the amino acid sequence of human H-FABP [10] (Fig. 2.5.) known at the time we started our experiments, a prediction about the secondary structure of the H-FABP molecule was made according to Chou and Fasman [11] (Fig. 2.6.). Putative antigenic sequences within this secondary structure were predicted using algorithms for hydrophilicity [12,13], $\alpha$-helix and B-turns [11,14], surface probability [15,16], and flexibility [17], culminating in an antigenic index according to Jameson and Wolf [8] and Wolf et al. [9].

Four amino acid sequences that included possible antigenic regions that scored 1.2 or higher on the antigenic index (Fig. 2.6.), designated SP1 (residues 10-25, KLVDSKNFDDYMKSLG), SP2 (residues 37-53, TKPTTIIEKNGDILTLK), SP3 (residues 97112, QKWDGQETTKVRELID), and SP4 (residues 120-134, THGTAVSTRTVEKEA) were selected for synthesis (for monocharacteral description of amino acids, see Table 2.2). Upon selection of the peptides to be synthesized strongly homologous regions 
were avoided. The selected sequences in H-FABP showed no significant degree of homology with human L-FABP, human serum albumin, transferrin, and the constant regions of $\lg A 1, \operatorname{IgM}$, and $\lg G$ subclasses.

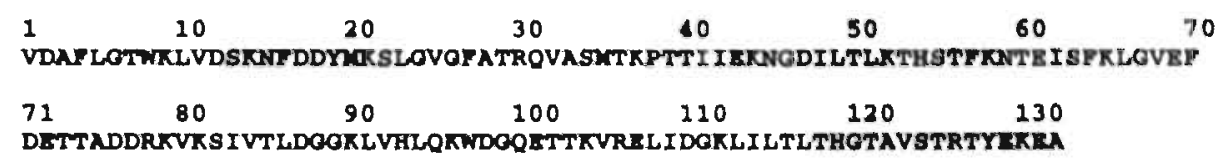

Figure 2.5. The amino acid sequence of human H-FABP according to Offner et al. (10). For monocharacteral description of amino acids, see Table 2.2 .

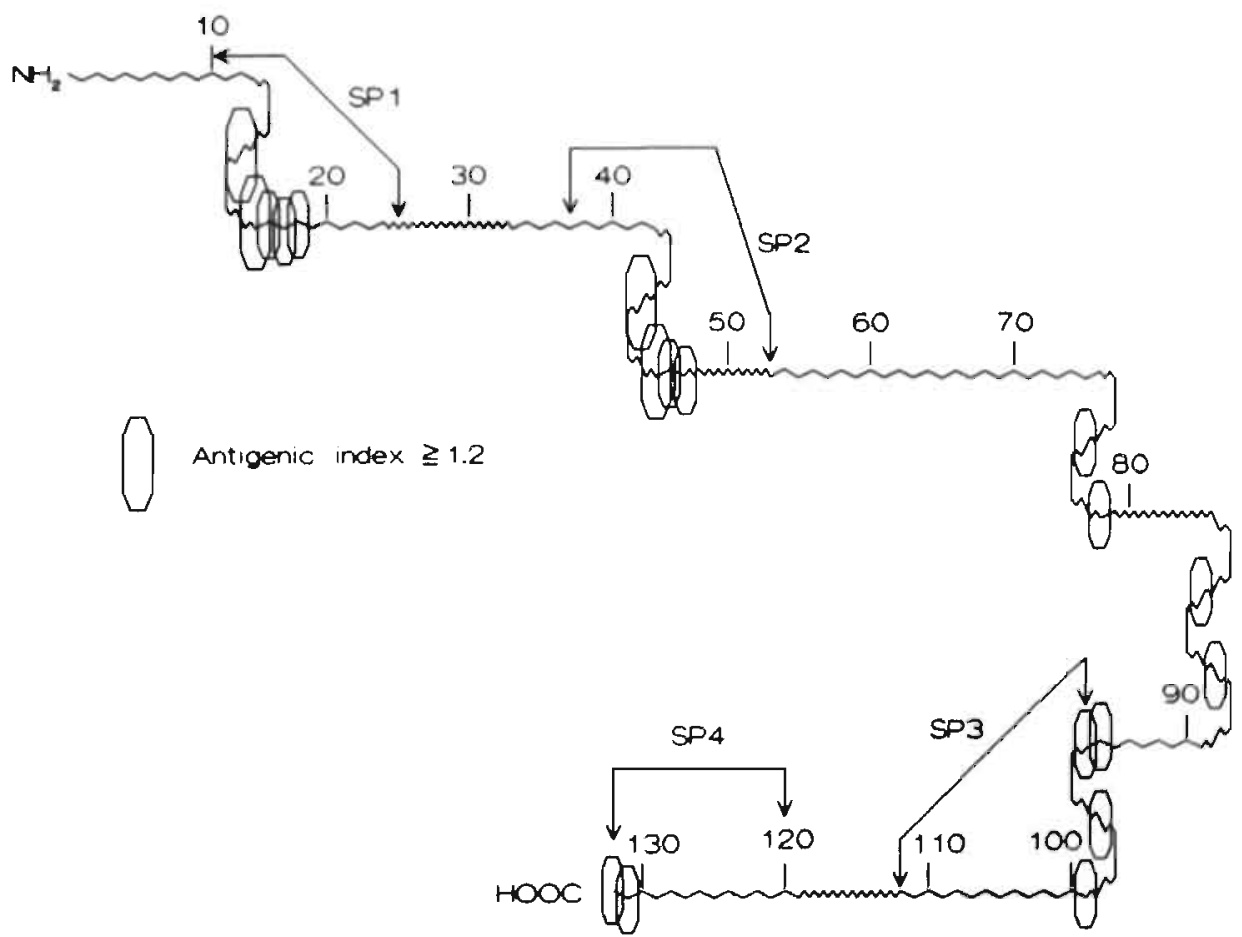

Figure 2.6. Secondary structure of a H-FABP molecule according to the Chou-Fasman prediction [10]. Following the method of Jameson and Wolf $[7,8]$ an antigenic index was computed and projected on to the secondary structure. Highly antigenic regions ( $\geq 1.2$ on the antigenic index) are indicated by hexagons. Regions between arrows indicate manufactured symthetic peptides (SP1-4, see section 2.5 . for details).

Peptides were produced by a solid-phase technique essentially according to Merrifield [18] and modified in detail as described by Van Laar et al. [19]. Briefly, Rapid-Amide beads were used with the use of F-moc protected amino acids (Dupont, Wilmington, USA) in the procedure as described for the RaMPS System 
(Dupont Medical products, Biotechnology Systems, USA). Piperidine was used for deprotection. Elongation was controlled at each step [20] and, in case of a proline, a modification was carried out according to the method described by Kaiser [21].

Final deprotection and cleavage were performed using a mixture of trifluoroacetic acid, phenol and ethanediol followed by precipitation from diethyl-ether. Cysteines with a tertiary butyl protection group were deprotected using mercury(II)acetate. Peptides were purified as described in detail elsewhere [22]. In short, peptides were reduced using B-mercaptoethanol and subsequently purified over $G$ 15 Sephadex in 5\% acetic acid. Fractions showing a single peak on reverse phase chromatography in a gradient of $0.1 \%$ trifluoroacetic acid in acetonitrile were pooled. Peptides SP1 and SP2 were conjugated to Keyhole Limpet Haemocyanin (KLH) with maleimidobenzoyl-N-hydroxysuccinimide [23] using the cysteine-SH groups as described elsewhere [24]. The peptides SP3 and SP4 were coupled to KLH using a glutaraldehyde coupling method [25]. Control conjugates of the peptides with bovine serum albumin were produced using a carbodiimide coupling [26].

Table 2.2. AMINO ACIDS AND THEIR ABBREVIATIONS.

\begin{tabular}{lll}
\hline Amino acid & $\begin{array}{c}\text { Three-letter } \\
\text { abbreviation }\end{array}$ & $\begin{array}{c}\text { One-letter } \\
\text { symbol }\end{array}$ \\
\hline Alanine & Ala & A \\
Arginine & Arg & $\mathrm{R}$ \\
Asparagine & Asn & $\mathrm{N}$ \\
Aspartic acid & Asp & $\mathrm{D}$ \\
Cysteine & Cys & $\mathrm{C}$ \\
Glutamine & Gln & $\mathrm{E}$ \\
Glutamic acid & Glu & $\mathrm{G}$ \\
Glycine & Gly & $\mathrm{H}$ \\
Histidine & His & $\mathrm{I}$ \\
Isoleucine & lle & $\mathrm{L}$ \\
Leucine & Leu & $\mathrm{K}$ \\
Lysine & Lys & $\mathrm{M}$ \\
Methionine & Met & $\mathrm{F}$ \\
Phenylalanine & Phe & $\mathrm{P}$ \\
Proline & Pro & $\mathrm{S}$ \\
Serine & Ser & $\mathrm{T}$ \\
Threonine & Thr & $\mathrm{W}$ \\
Tryptophan & Trp & Y \\
Tyrosine & Tyr & V \\
Valine & Val & \\
\hline
\end{tabular}

\subsection{Preparation of antibodies.}

\section{Antibodies against synthetic peptides.}

Rabbits. For each of the four synthetic peptides (section 2.5.) two rabbits (Flemish giant) were immunized intracutaneously with KLH-SP conjugate in a mixture of PBS and Freund's Complete Adjuvant (FCA). The $2 \mathrm{ml}$ of injection fluid 
(PBS:FCA=1:1 v/v), was divided equaliy over four injection sites along the backside of the rabbit. After four weeks the rabbits were boosted subcutaneously with the same amount of immunization mixture. The second boosting was carried out in week 8, using Freund's Incomplete Adjuvant instead of FCA. Two weeks after the second booster blood was collected in glass tubes and allowed to clot, while cooled on ice, for one hour. After centrifugation at $1,500 \times \mathrm{g}$ for 10 minutes, the resulting supernatant serum was transferred to another test tube and heated at $56^{\circ} \mathrm{C}$ for one hour to block any endogeneous peroxidase activity in the serum. Aliquots of the sera were frozen at $-20^{\circ} \mathrm{C}$ until further use.

Mice. Four groups of four female mice (Balb/C) were immunized intraperitoneally with $20 \mu \mathrm{g}$ of antigen (human H-FABP or KLH-SP conjugates) in an PBS/oil-emulsion [27]. The same emulsion was used four and eight weeks later for the first and the second booster, respectively.

\section{Antibodies against purified human H-FABP.}

Antibodies against purified human H-FABP were raised in rabbits (Flemish giant) using the immunization and boosting protocol as described above for rabbit antibodies against synthetic peptides. For each injection $200 \mu \mathrm{g}$ of purified H-FABP in PBS/FCA was used.

\subsection{PURIFication of POlyclonal antibodies.}

The rabbits were bled two weeks after the last injection and the antibodies against human H-FABP were specifically isolated from serum by a two-step affinity chromatography procedure. In the first step the total IgG fraction was isolated by means of protein-A chromatography, following the instructions of the manufacturer. Subsequently monospecific rabbit IgG against human H-FABP was isolated from the total IgG fraction by affinity chromatography, using a CNBractivated Sepharose $4 \mathrm{~B}$-column to which purified human H-FABP was covalently bound (section 2.3.), again following the manufacturers instructions. The resulting antibody solution was dialysed against PBS overnight and aliquots were stored at $4^{\circ} \mathrm{C}$ in PBS, supplemented with $0.02 \%(\mathrm{w} / \mathrm{v}) \mathrm{NaN}_{3}$, until further use.

\subsection{FATTY ACID-BINDING STUDIES WTTH H-FABP.}

Binding of $\left[1-{ }^{14} \mathrm{C}\right]$ oleic acid (specific activity $54.9 \mathrm{Ci} / \mathrm{mol}$ ) to $\mathrm{H}-\mathrm{FABP}$ was studied with the Lipidex 1000 assay as described originally by Glatz and Veerkamp [2] and modified by Vork et al. [28]. The concentration of the human H-FABP solution used for the binding studies was determined by amino-acid HPLC analysis (section 2.4.). Data of the binding studies were analyzed according to Zivin and Waud [29] and visualized using an Eadie-Hofstee plot (Fig. 2.7.). The intercept of the $Y$-axis represents the maximal fatty acid-binding $\left(B_{\max }\right.$ ) while the dissociation constant $\left(K_{d}\right)$ was derived from the slope of the curve. Maximal 
binding of oleate to $\mathrm{H}-\mathrm{FABP}$ was found to be $0.75 \pm 0.01$ (mean $\pm \mathrm{SD}, \mathrm{n}=1$ ) moles per mol H-FABP. The value of $B_{\max }$ is lower than the binding capacity of $1 \mathrm{~mol}$ fatty acid per mol H-FABP as found for rat heart FABP by Vork et al. [28].

However, other studies with human and rat H-FABP also showed lower maximal binding of oleate to H-FABP [30]. The discrepancy can not be ascribed to any impurities in the H-FABP samples used for these studies, for we showed that the H-FABP sample was pure (section 2.3.). A possible explanation of the discrepancy could be that human H-FABP interacts slightly different with Lipidex than other investigated FABP types, which in turn could be caused by slight denaturation or alteration of the human $\mathrm{H}-\mathrm{FABP}$ molecule during purification. Because denaturation or alteration of the human H-FABP molecule during purification have not been investigated, the explanation remains speculative. The dissociation constant $K_{d}$, calculated from the results of the binding studies, was $0.19 \pm 0.01 \mu \mathrm{M}$.

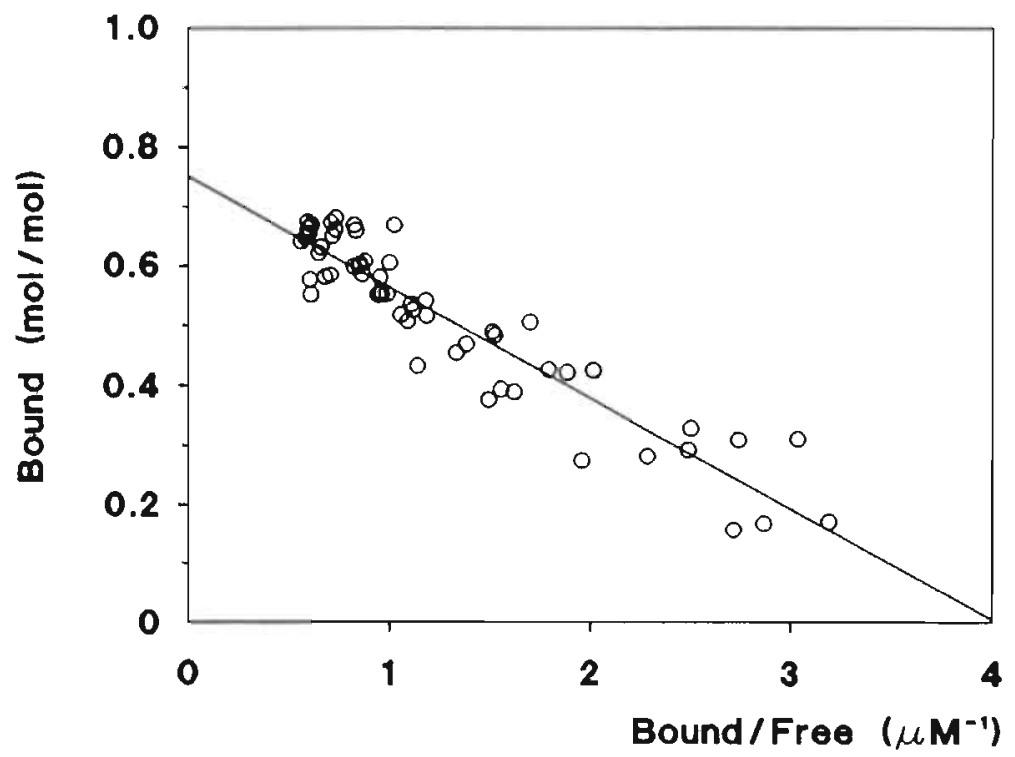

Figure 2.7. Eadie-Hofstee plot of the binding of ${ }^{4} \mathrm{C}$-oleate by human H-FABP. The parameter on the $x$-axis represents $\mathrm{mol}$ of fatty acids bound per $\mathrm{mol}$ of H-FABP $(\mathrm{mol} / \mathrm{mol})$, and the parameter on the $y$-axis represents the ratio of the bound fatty acids (mol fatty acid/mol H-FABP) and the concentration of free (unbound) fatty acids $(\mu \mathrm{M})$. Thus the Bound/Free ratio is given in $(\mu \mathrm{M})^{-1}$. Maximal oleate binding $\left(\mathrm{B}_{\mathrm{in}}\right)=0.75+0.01$ moles of fatty acids per mol of H-FABP, and the dissociation constant $\left(\mathrm{K}_{\mathrm{f}}\right)=$ $0.19 \pm 0.01 \mu \mathrm{M}$. 


\subsection{IMMUNO- AND ENZYME-HISTOCHEMISTRY.}

\section{Tissues.}

Myocardial tissue samples were obtained during autopsies performed in the department of Pathology (head Prof. Dr. J-W. Arends) of the Academic Hospital Maastricht (Maastricht, the Netherlands). In each case an approximately $0.75 \mathrm{~cm}$ thick transverse section of the heart, located halfway between the apex and the annulus fibrosis and parallel to the atrio-ventricular sulcus, was excised for the macroscopic nitroblue tetrazolium staining (NBT-staining). From the adjacent part of the heart four tissue samples were collected. Each of these samples, originating from the posterior, lateral and anterior wall (including the septum) of the left ventricle and one from the right ventricle, was excised around the drainage areas of the main coronary arteries. Tissue samples from non-myocardial tissues were retrieved from the archives of the department of Pathology of the Academic Hospital Maastricht.

\section{Macroscopic NBT-staining.}

The NBT-staining of myocardial tissue samples was performed immediately on site during the autopsy, essentially according to the method Kubat [31]. After rinsing with saline $(0.9 \% \mathrm{NaCl}$ in aqua dest) the transverse section was immersed in freshly prepared incubation medium, consisting of $80 \mathrm{mM}$ phosphate buffer ( $\mathrm{pH}$ 7.2), supplemented with $80 \mathrm{mM}$ DL-lactic acid, $6 \mathrm{mM} \mathrm{NBT}$ and $75 \mu \mathrm{M}$ NAD. The medium containing the tranverse section was gently shaken throughout the incubation time and every 5 seconds the section was turned over to avoid artifacts resulting from the section being too long in contact with the bottom of the incubation medium container. After 5 minutes the reaction was stopped by immersion of the section in formalin $(10 \%, \mathrm{v} / \mathrm{v})$. Results of the staining were evaluated with the section being immersed either in formalin or water.

\section{Tissue fixation, embedding, sectioning and mounting.}

Human tissue samples for immunostaining and conventional histochemical staining were fixed by immersion in buffered formalin, $\mathrm{pH} 7.0(4 \%, \mathrm{v} / \mathrm{v})$, for at least 24 hours. Subsequently the tissue samples were processed for paraffine wax embedding using a Vacuum Impregnation Programmer. Sections of $3 \mu \mathrm{m}$ were cut on a rotation microtome, stretched on a luke-warm water surface $\left(37^{\circ} \mathrm{C}\right)$ and subsequently mounted on glass slides, previously coated with joiner's glue.

\section{Staining.}

During dewaxing and hydration of the tissue sections in degrading alcohol possible endogenous peroxidase activity was blocked with $0.6 \% \mathrm{H}_{2} \mathrm{O}_{2}$-methanol. Tissue sections were incubated for 30 minutes in a moist chamber with monospecific polyclonal rabbit IgG against human H-FABP (section 2.7.) in a 1:250 dilution in PBT (phosphate buffered saline, supplemented with $0.1 \%[\mathrm{w} / \mathrm{v}]$ bovine 
serum albumin and $0.1 \%[\mathrm{v} / \mathrm{v}]$ Tween-20). Bound rabbit antibodies were detected with swine-anti-rabbit IgG conjugated with horseradish peroxidase, in a dilution of 1:250 in PBT. Diaminobenzidine $(5 \mathrm{mg}$ DAB $+9 \mathrm{ml}$ Tris- $\mathrm{HCL}+1 \mathrm{ml}$ Imidazole $(0.1$ M) $\left.+5 \mathrm{\mu l} \mathrm{H}_{2} \mathrm{O}_{2}[30 \%]\right)$ was used as chromogen. Tissue sections were weakly counterstained with haematoxylin. Sole staining of tissue sections with haematoxylin-eosin was used as the conventional staining technique.

\subsection{MEASUREMENT OF THE MYOGLOBIN PLASMA CONCENTRATION.}

The concentration of myoglobin in plasma was measured using a turbidimetric immunoassay on a Turbitimer analyzer. Assay of myoglobin was performed according to the method of Delanghe et al. [32]. Turbiquant Myoglobin is a freezedried reagent consisting of polystyrene shell/core particles (size $100 \mathrm{~nm}$ ) coated with rabbit anti-human myoglobin antibodies. The lyophilized reagent is resuspended with $10 \mathrm{ml}$ of citrate buffer $(\mathrm{pH} \mathrm{7.8)}$. In the assay a cuvette is filled with $50 \mu \mathrm{l}$ plasma and $500 \mu \mathrm{l}$ of suspended latex particles. Dilutions of plasma were made in saline $(0.9 \% \mathrm{NaCl})$. The myoglobin concentration is determined by turbidimetric measurement of the maximum reaction velocity (peak-rate method). The bar code on the package insert contains the calibration information needed for the assay-package in use. The detection limit of the method is $50 \mu \mathrm{g} / \mathrm{l}$. The preprogrammed measuring range covers myoglobin concentrations from $50-650 \mu \mathrm{g} / \mathrm{l}$.

Internal quality control was performed using the human Apolipoprotein Control Serum CHD. Day to day variation was obtained by measuring the control serum on 22 subsequent days resulting in a mean concentration of $97.4 \mu \mathrm{g} / \mathrm{l}$ and a day to day variation of $4.8 \%$.

\subsection{Measurement of CK, CK-MB AND A-HBDH ACtivity.}

Activities of $\mathrm{CK}, \mathrm{CK}-\mathrm{MB}$ and $\alpha-\mathrm{HBDH}$ were measured spectrophotometrically in duplicate at $25^{\circ} \mathrm{C}$, using a centrifugal analyzer and commercially available test kits. The CK-MB test is based on immunoinhibition of the predominant $\mathrm{M}$ unit in creatine kinase. The $\alpha-\mathrm{HBDH}$ test is based on enhanced catalytic activity of the myocardial isoforms $\mathrm{LDH}_{1}$ and $\mathrm{LDH}_{2}$ of lactate dehydrogenase in the conversion of $\alpha$-ketobutyrate, instead of pyruvate [33]. Activities were expressed in micromoles of substrate converted per minute per litre of plasma (U/l). 


\subsection{SOURCE OF MATERIALS.}

\section{Protein and antibody purification.}

-Pharmacia Phast System for SDS-PAGE and IEF, UV-monitor (UV-1), Fraction collector (2211 Superrac), as well as all columns and column materials for chromatography by Pharmacia/LKB, Uppsala, Sweden,

-Lipidex-1000 by Packard Instrument Company Inc., Downers Grove, Illinois, USA,

-'C-Oleate by Amersham International, Amersham, UK,

-Flatbed recorder: BD-100 by Salm \& Kipp \& Zonen, Bergen op Zoom, the Netherlands,

-All materials for ultrafiltration (Diaflo) by Amicon, Danvers, Massachusetts, USA.

\section{Measurement of enzyme activity.}

-CK: Assay kit \#12135, by Merck Diagnostica,

-CK-MB assay ( $\# 418234$ ) and $\alpha-\mathrm{HBDH}$ activity assaly (kit $\$ 161080$ ) by Boehringer Mannheim GmbH, Germany,

-Centrifugal analyzer: Cobas Bio System by Hoffman La Roche, Basel, Switzerland.

Measurement of myoglobin concentration.

-Turbitimer analyzer, Apolipoprotein Control Serum CHD, OUPH 06/07 (lot \#063617, assigned value $95 \mu \mathrm{g} / \mathrm{l}$ and confidence limit $81-109 \mu \mathrm{g} / \mathrm{l}$ ), and Turbiquant immunoassay (code \# OWNL) by Behring, Hoechst Holland, Amsterdam, the Netherlands.

\section{Immuno- and enzyme-histochemistry.}

-Embedding material for tissue sections: Entellan (\#7961) by Merck, Darmstadt, Germany,

-Antibodies: Swine anti Rabbit IgG (conjugated with Horseradish Peroxydase, \#P217) by Dakopatts, Glostrup, Denmark,

-Nitroblue Tetrazolium (NBT, \#N-6876), DL-lactic acid (\#L-1375), Nicotinamide Adenine Dinucleotide (NAD, \#N-7004), and Diaminobenzidine (DAB, \#D-5637) by Sigma, St. Louis, USA,

-Phosphate Buffer: GURR (\#65500) by Pharbil bv, Rotterdam, the Netherlands,

-Vacuum Impregnation Programmer (VIP) by Bayer,

-Rotation microtome: Type $\mathrm{J} 1130$ by Reichert-Jung. 


\subsection{REFERENCES.}

1. Glak JFC, Janssen AM, Baerwaldt CCF, Veerkamp JH: Purification and characterization of falty acid-binding proteins from rat heart and liver. Biochim Biophys Acta 837: 57-66, 1985.

2. Glatz. JFC, Veerkamp JH: A radiochemical procedure for the assay of fatty acid binding by proteins. Anal Biochem 132 89-95, 1983.

3. Van Nieuwenhoven FA, Vork MM, Surtel DAM, Kleine AH, Van der Vusse G], Glatz JC: A highyield two step chromatographical procedure for purification of fatty acid-binding protein from human heart / Chromatography 570: 173-179, 1991.

4. Withaker JR, Granum PE: An absolute method for protein determination based on difference in absorbance at 235 and $280 \mathrm{~nm}$. Anal Biochem 109: 156-159, 1980.

5. Lowry O, Rosenbrough NJ, Farr AL, Randall R: Protein measurement with the Folin phenol reagens. I Biol Clum 193: 265-275, 1951.

6. Bradford MM: A rapid and sensitive method for the quantitation of microgram quantities of protein utilizing the principle of protein-dye binding. Anal Biachem 72: 248-254, 1976.

7. Van Eijk HMH, Van der Heijden MAH, Van Berlo CLH, Soeters PB: Fully automated liquidchromatographic determination of amino-acids. Clin Chem 34: 2510-2513, 1988

8. Jameson $\mathbf{B A}$, Wolf $\mathrm{H}$ : The antigenic index: a novel algorithm for predicting antigenic determinants. Cabios 4: 181-186, 1988.

9. Wolf H, Modrow S, Motz M, Jameson BA, Hermann, G., Förtsch, B.: An integrated family of amino acid sequence analysis programs. Cabios 4: 187-191, 1988.

10. Offner GD, Brecher P, Sawlivich WB, Costello CE, Troxler RF: Characterization and amino acid sequence of a fatty acid-binding protein from human heart. Biochem / 252: 191-198, 1988.

11. Chou PY, Fasman R: Prediction of the secondary structure of proteins from their amino acid sequence. Adv Frizymol, 45-148, 1978

12. Hopp TP, Woods KR: Prediction of protein antigenic determinants from amino acid sequences Proc Natl Acid sici USA 78: 3824-3828, 1981.

13. Kyte J, Dowlittle RF: A simple method for displaying the hydropathic character of a protein. J Mol Biol 157: 105-132, 1982.

14. Gamier J, Osguthorpe DJ, Robson B: Analysis of the accuracy and implications of simple methods for predicting the secondary structure of globular proteins. I Mol Biol 120: 97-120, 1978.

15. Emini EA, Jameson BA, Wimmer E: Priming for and induction of anti-poliovirus neutralizing antibodies by synthetic peptides. Nature 304: 699-703, 1983.

16. Emini EA, Hughes JV, Perlow DS, Boger J: Induction of hepatitis A virus-neutralizing antibody by a virus specific synthetic peptide. / Virol 55: 836-839, 1985.

17. Karplus PA, Schulz GE: Prediction of chain flexibility in proteins. A tool for the selection of peptide antigens. Naturwissensciaften 72: 212-213, 1985.

18. Merrifield RB: Solid phase peptide synthesis. I. The synthesis of a tetra peptide. / Am Chem Soc 85: 2149-2154, 1963.

19. Van Laar JH, Voorhorst-Ogink MM, Zegers ND, Boersma WJA, Claassen E, Van der Korput JAGM, Ruizeveld de Winter JA, Van der Kwast ThH, Mulder E, Trapman J, Brinkman AO: Characterization of polyclonal antibodies against the $\mathrm{N}$-terminal domain of the human androgen receptor. Mol Cell Endocrinol 67: 29-38, 1989.

20. Kaiser E, Colescott RL, Bossinger CD, Cook PI: Color test for detection of free terminal amino groups in the solid phase synthesis of peptides. Anal Biochem 34: 595-599, 1970.

21. Kaiser E, Bossinger CD, Colescott RL, Olsen DB: Color test for terminal prolyl residues in the solid-phase synthesis of peptides. Anal Chim Acta 118: 149-151, 1980.

22. Van Denderen J, Hermans A, Meeuwsen T. Troelstra C, Zegers ND, Boersma W]A. Grosveld G, Van Ewijk W: Antibody recognition of the tumor-specific bcr-abl joining region in chronic myeloid leukemia. J Exy Med 169: 87-98, 1989.

23. Kitagawa $T$, Aikawa $T$ : Enzyme coupled immunoassay of insulin using a novel coupling agent. I Biochen 79: 233-236, 1976.

24. Schoentgen F, Pignede $G$, Bonanno LM, Jolles $P$ : Fatty-acid-binding protein from bovine brain. Amino acid sequence and some properties. Eur / Biochem 185: 35-40, 1989. 
25. Zegers ND, Gerritse K, Deen C, Boersma WIA, Claassen E: Atn improved conjugation method for controlled covalent coupling of synthetic peptides to proteinsi using glutaraldehyde in a dialysis method. / Immunol Meth $130.195-200,1990$.

26. Deen D, Claassen E, Gerritse K, Zegers ND, Boersma WJA: A novel carbodilimide coupling method for synthetic peptides: enthanced anti-peptide antibody responses. I Immunol Meth 129: 119-125, 1990.

27. Bokhout BA, Van Gaalen C, Van der Heijden 1: A selected water-in-oil emulsion: Composition and usefulness as an immunological adjuvant. Vet Immunol Immunopathol 2: 491.500, 1981.

28. Vork MM, Glatz JFC, Surtel DAM, Van der Vusse GJ: Assay of the binding of fatty acids by proteins: evaluation of the lipidex 1000 procedure. Mol Cell Biochem $\$ 8: 111-117,1990$

29. Zivin JA, Waud DR: How to analyze binding, enzyme and uptake data: The simplest case, a single phase. Life Sciences 30: 1407-1422, 1982.

30. Paulussen RJA, Van der Logt PE, Veerkamp JH: Characterization and binding properties of latty acid-binding proteins from human, pig, and rat heart. Arch Biochem Biophys 264: 533-545, 1988.

31. Kubst K: On the pathological anatomy of nnyocardial infarction. Hart Bulletin 2: 33-40, 1971.

32. Delanghe J. Chapelle J-P, El Allaf M, De Buyzere M: Quantitative turbidimetric assay for determining myoglobin evaluated. Ann Clin Biochenn 28: 474-470, 1991.

33. Rosalki SB, Wilkinson JH: Reduction of alpha-ketobutyrate by human serum. Nature 188: 1110$1111,1960$. 
CHAPTER 3

\section{AN IMMUNOCHEMICAL ASSAY FOR HUMAN HEART FATTY ACID-BINDING PROTEIN Development and Validation}

3.1. Introduction p 36

3.2. Types of immunochemical assays p 36

3.3. Labelling antibodies $p 40$

3.4. Performance of the assays: General procedures $\mathrm{p} 41$

3.5. Performance of the assays: Determinations of antisera titres $p 42$

3.6. Measurement of H-FABP in human plasma samples p 44

3.7. References p 46 


\subsection{INTRODUCTION.}

Measurement of cytoplasmatic human heart fatty acid-binding protein $(\mathrm{H}$ FABP) in blood samples and/or tissues from cardiac patients is not only of basic scientific importance, but in the end might also be of clinical importance. We therefore aimed to develop a sensitive assay for measuring H-FABP in the laboratory that would meet the high standards of specificity, accuracy and reproducibility required for clinical assays. In this chapter we will discuss in detail the features of an immunoassay system for measurement of FABP in human blood.

Immunoassays are valuable tools for identification, localisation and/or quantitation of all sorts of analytes (antigens and antibodies) in body fluids or tissue preparations, and therefore used in almost every field of biological and medical research. All types of immunoassays have in common that labelled antigens or antibodies are used for the ultimate visualization of the analyte. A wide variety of labels is available, such as radioisotopes ( $c$. iodine), enzymes ( $c f$. horseradish peroxidase), and fluorochromes (cf. fluorescein) [1]. Since 1966 antibodies labelled with enzymes have also been used for the immunohistochemical localization of antigen in tissue sections [2]. In 1971 enzymes conjugated with antibodies [3] or with antigen [4] were, for the first time, used as labels in a solid-phase enzyme-linked immunosorbent assay (ELISA) for quantification of an analyte. Since then numerous variations on the ELISA have been designed and developed, but all those variations can still be divided into three distinct classes of immunoassays, namely (1) the antibody capture assays, (2) the antigen capture assays, and (3) the two-antibody sandwich assays, [5]. All three types of assays are carried out on a solid-phase matrix (e.g. microtiter plate).

\subsection{TYPES OF ENZYME-LINKED IMMUNOCHEMICAL ASSAYS.}

\section{The antibody capture assay.}

The general performance of this assay is as follows:

First, the purified antigen is physically bound to the microtiter plate by simple adsorption (Fig. 3.1*). Next, enzyme-labelled antibodies directed against the antigen is added to the wells (Fig. $3.1^{b}$.). These antibodies, also termed 'Detector'-antibodies (DeAbs) because they detect the bound antigen, will naturally react with the immobilized antigen. In the last step of the assay a suitable substrate solution is offered to the bound enzyme-labelled DeAbs, upon which a soluble coloured product is formed (Fig.3.1'.). Extinction is measured spectrophotometrically. Because the amount of bound DeAbs is directly proportional to the amount of bound antigen, the latter can be quantitated by comparison with known standard amounts of antigen. Positive and negative controls should also be included in the assay.

In the abuve general description of the assay the DeAbs are labelled with an enzyme, thus making it a direct assay. In case the DeAbs are or can not be labelled a third (labelled) antibody from a different species is needed to detect the DeAbs (Fig.3.2.). The assay is then said to be an indirect one. 


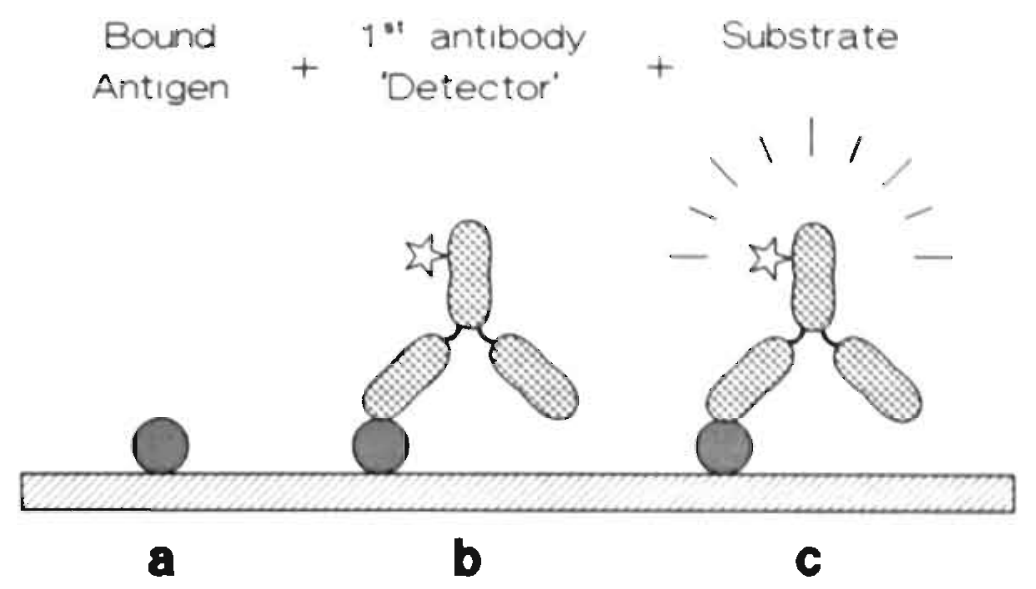

Figure 3.1. Diret antibody capture assay. a; Incubation of the wells on the microtiter plates with coating buffer containing antigen, $\mathbf{b}$; Incubation of the wells with enzyme-labelled detuctor-antibodies (DeAbs) against the antigen, $c$; Incubation of the wells with a substrate solution, suitable for the enzyme, followed by spectrophotometric reading of the microtiterplate after stopping of the enzyme reaction.

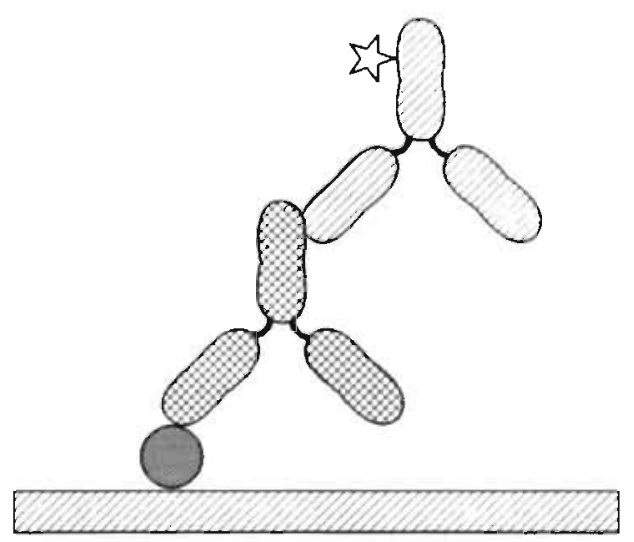

Figure 3.2. In an indirect antibody capture assay the first two steps are identical to the direct antibody capture assay (Fig. 3.1.a and b), except that the first antibody (DeAbs) in the indirect antibody capture assay is not labelled itself. Therefore a third, enzyme-labelled, antibody against the second antibody is added. After addition of a suitable substrate solution the degree of coloration is proportional to the amount of DeAbs bound to the immobilized antigen.

\section{The antigen capture assay.}

In general this type of assay is used to determine the concentration of antigen in samples with unknown quantity of antigen (Figure 3.3.). The first step in this 
type of assay is the coating of specific antibody on a solid-phase matrix. Because these antibodies are supposed to capture the antigen in the next step of the assay they are also known as 'Catcher'-antibodies (CaAbs). Next, the test solution is mixed with a certain amount of purified and labelled antigen and added to the matrix. During incubation labelled and unlabelled antigens will compete for the binding sites on the immobilized antibodies. The more unlabelled antigens in the sample, the less labelled antigens can bind to the antibodies resulting in a reduced staining after the substrate is added. To quantitate the amount of bound unlabelled antigen, dilutions of the test solution have to be performed and assayed.

Comparison of the calibration curves for each solution will yield the relative levels of antigen. The absolute amount of antigen is determined by comparison of the relative values with values obtained in a standard curve with known amounts of pure unlabelled antigen.

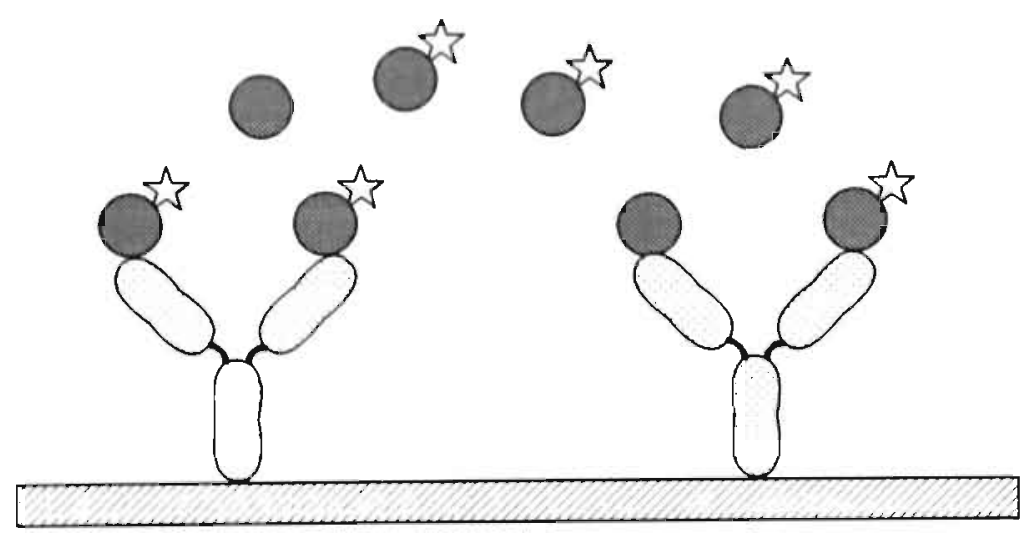

Figure 3.3. Antigen capture assay. A test solution, mixed with a certain amount of purified and labelled antigen, is added to the matrix (immobilized specific antibodies). Quantitation of bound unlabelled antigen is determined by comparison of the results of the assay with different dilutions of the test solution (see section 3.2.3. for details).

\section{The two-antibody sandwich assay.}

The simplest form of the two-antibody sandwich assay, namely a direct noncompetitive sandwich ELISA, is depicted in Figure 3.4. On a microtiter plate this assay is generally performed as follows:

- CaAbs are bound to a solid phase (Fig.3.4.), followed by adding appropriately diluted biological samples to the wells. During incubation specific analytes (antigens) will bind to the antibodies bound to the solid phase (Fig.3.4. ${ }^{\mathrm{b}}$.).

- Subsequently, DeAbs are added to the wells (Fig.3.4.) which will, as in the antibody capture assay, react with the bound antigen. The adding of a suitable substrate solution (Fig. $3.4^{\mathrm{d}}$ ), followed by measurement of the extinction, completes the direct Sandwich ELISA. 
In an indirect non-competitive sandwich ELISA the DeAbs are not labelled, thus for visualization a third (labelled) antibody from a different species must be added (Fig.3.5.). Obviously the more popular name Sandwich ELISA for this type of assay stems from the fact that at the end of the assay the antigen is located between two antibodies.

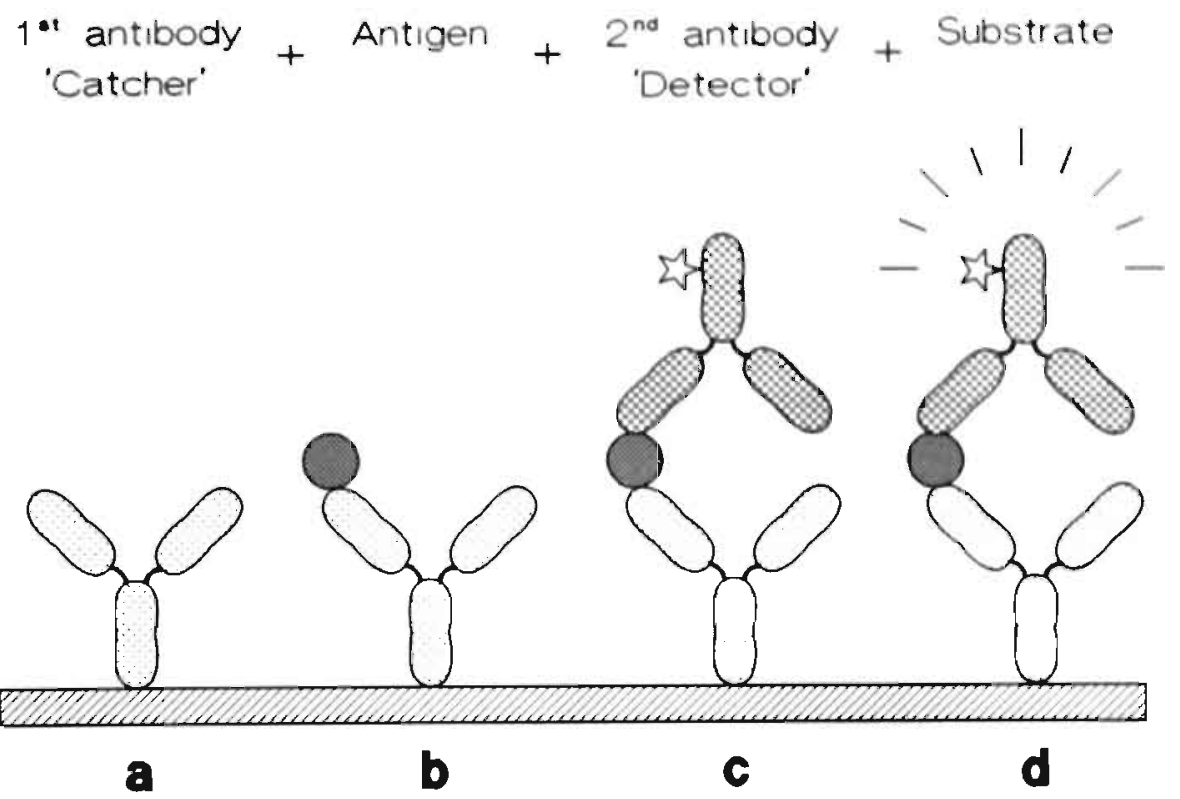

Figure 3.4. Direct ELISA for antigen measurement. a; Incubation of the wells on the microtiter plates with coating buffer containing unlabelled catcher-antibodies (CaAbs) against the antigen to be measured, b; Incubation of the wells with diluted biological or clinical samples containing an unknown amount of antigen, $c$; Incubation of the wells with enzyme-labelled detector-antibodies (DeAbs) against the antigen, $\mathrm{d}$; Incubation of the wells with a substrate solution, suitable for the enzyme, followed by spectrophotometric reading of the microtiterplate after stopping of the enzyme reaction.

We employed the antibody-capture assay (direct as well as indirect) for testing the activity and the optimal dilution (titre) of our antisera from mice, rabbits and goats (section 5). The possible loss of activity of monospecific polyclonal IgG fractions after affinity purification of the antisera (Chapter 2 section 7), as well as possible loss of activity after conjugation of IgG with enzyme (section 3), was also tested with use of the antibody capture assay. This assay is in essence also the method which is used for immunohistochemical staining of tissue sections, as described in Chapter 7.

For a number of reasons the direct non-competitive sandwich ELISA was chosen for the measurement of the quantity of H-FABP in human plasma samples (Chapter 5) in the present study. First of all, this type of ELISA involves the least number of steps to perform a sandwich ELISA, making the assay rapid and easy. Secondly, the assay can easily be quantified with the use of a calibration curve 
(section 3.6.). Thirdly, when performed with affinity purified antibodies as in the present study, the sandwich ELISA shows high sensitivity, specificity [5], and good reproducibility (section 3.6.). Fourthly, an ELISA of this type is virtually undisturbed by the presence of other plasma components because the CaAbs will only bind H-FABP molecules.

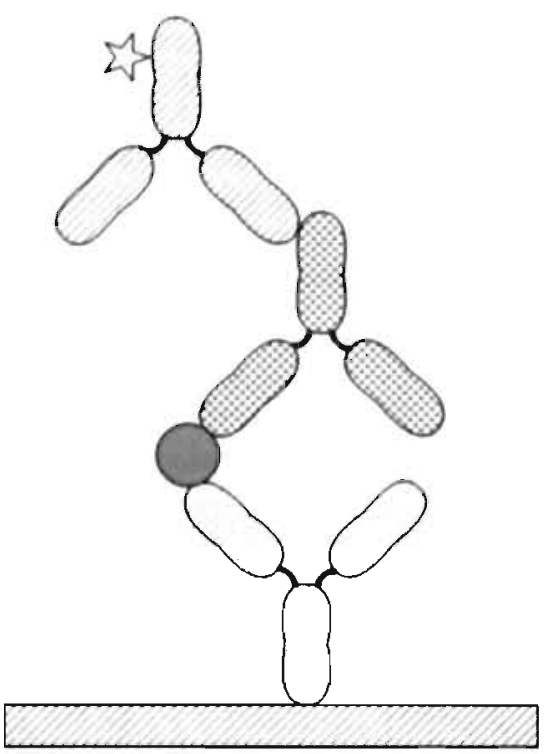

Figure 3.5. Indirect ELISA for antigen measurement. The first three steps in this assay are identical to the direct ELISA (Fig. 3.4.a-c), except that the second antibody (DeAbs) in the indirect ELISA is not labelled itself. Therefore a third, enzyme-labelled, antibody against the DeAbs is added. After addition of a suitable substrate solution the degree of coloration is proportional to the amount of antigen present.

\subsection{LABELling ANTIBODIES WITH HORSERADISH PEROXIDASE.}

Antibodies can easily be labelled by coupling them covalently to enzymes [for reviews see refs. 6,7]. From the large number of enzymes available for labelling antibodies (e.g. horseradish peroxidase, alkaline phosphatase and $\beta$-galactosidase) we have chosen horseradish peroxidase (HRP) because it is easy to conjugate it with an antibody and because the conjugate shows remarkable stability while being not too large. Furthermore, HRP is relatively cheap.

\section{Conjugation procedure.}

The conjugation procedure was performed according to Tijssen and Kurstak [8]: Firstly, $5 \mathrm{mg}$ HRP (Sigma \#P-6782, type VI-A) is dissolved in $500 \mu$ l freshly prepared $\mathrm{NaHCO}_{3}$-solution $(0.1 \mathrm{M}, \mathrm{pH} 8.1)$ using a closed light-tight test-tube. Subsequently, $500 \mu \mathrm{l}$ freshly prepared $\mathrm{NaIO}_{4}$-solution $(10 \mathrm{mM})$ is added and the test-tube is placed in the dark for two hours at room temperature, while being 
constantly shaken. This procedure generates aldehyde groups of HRP by oxidation of glycol groups, and the HRP is then called 'activated'.

Next, $1.5 \mathrm{ml}$ of purified (Chapter 2 section 7) Immunoglobulin G-solution (10) $\mathrm{mg} / \mathrm{ml}$ in $0.1 \mathrm{M}$ sodium carbonate buffer, $\mathrm{pH} \mathrm{9.2)} \mathrm{is} \mathrm{added} \mathrm{to} \mathrm{the} \mathrm{activated} \mathrm{HIRP.}$ solution, followed by $450 \mathrm{mg}$ of dry Sephadex G-25 column material (Pharmacia/ LKB, Uppsala, Sweden). Because the pores in the Sephadex G. 25 beads are to small for IgG or HRP molecules addition of Sephadex increases the concentration of the antibody and the activated HRP, and simultaneously brings about a relative decrease of the $\mathrm{NaIO}_{4}$ concentration. The test-tube is replaced in the dark for three hours at room temperature, again under constant shaking. During this step the antibodies will conjugate with HRP through reaction of the HRP-aldehyde groups with the amino groups of the protein.

After three hours of conjugation the contents of the test-tube are poured into a glass chromatography column, equipped with a cloth of glasswool at the outlet side. The conjugate is eluted from the column using as little as possible $(5-6 \mathrm{ml})$ aqua tridest, and freshly prepared $\mathrm{NaBH}_{4}$-solution $(0.13 \mathrm{M}$ in $0.1 \mathrm{mM} \mathrm{NaOH})$ is added to the eluate ( $5 \%$ of total eluted volume). The conjugate solution is then placed in the dark for 30 minutes at room temperature, followed by adding more freshly prepared $\mathrm{NaBH}_{4}$-solution (15\% of total eluted volume) and another hour in the dark at room temperature. This procedure stabilizes the conjugate through the reduction of Schiff's base by the $\mathrm{NaBH}_{4}$.

The Immunoglobulin G-Horseradish peroxidase conjugate (IgG-HRP) is separated from unbound IgG and HRP by means of gelpermeation chromatography. Because this separation step is also performed to remove $\mathrm{NaBH}_{4}$ and traces of $\mathrm{NaIO}_{4}$, if any, it should be done immediately after the stabilization step.

\subsection{Performance of the assays: General procedures.}

\section{Washing.}

In an immunoassay unbound (excessive) molecules have to be removed after each incubation step. This is achieved by washing the wells of the microtiter plate with buffer containing a non-ionic detergent (e.g. Tween-20) and protein (e.8. bovine serum albumin [BSA]). In the washing step the wells are first filled to the rim with washing buffer. Next the assay plate is inverted and the wells are emptied with a quick vertical shake. Remaining washing buffer is removed by gently tapping the inverted plate on absorbing tissue until the wells are visually dry. This 'Wash-and-Flick' procedure is routinely repeated five times in every washing step, and is carried out after every incubation step.

\section{Blocking.}

During the first washing step the unbound sites on the solid phase are saturated ('blocked') with albumin in the washing c.q. blocking buffer, thus preventing non-specific binding of substances during the following steps of the assay. 


\section{Storage.}

After the plate has been coated with antibody or antigen and the empty sites on the plate have been blocked in the following washing step, it is possible to store the plate by drying the emptied plate and subsequently freezing $\left(-20^{\circ} \mathrm{C}\right)$ or sealing it in air tight, waterproof packs. Frozen coated plates have a theoretically infinite shelf life, while dried ones are reported to keep their activity for more than a year [9]. Storing coated plates has the advantage that a large amount of identical coated plates can be made in advance, taking away the need for performing a coating step when doing the actual assay. Hence, these 'ready-to-use' plates will help to reduce the time needed for the assay. Normally a sodium carbonate buffer can be used for coating buffer. But because a sodium carbonate buffer will leave salt crystals on the plate after drying - which possibly can damage the coating - plates meant to be stored are usually coated with antigen or antibody dissolved in ammonium carbonate buffer $(0.1 \mathrm{M}, \mathrm{pH} 8.8)$. During the drying process the ammonium carbonate will evaporate, thus leaving no salt crystals.

\subsection{Performance of the assays: Determinations of antisera titres.}

The optimal dilution of an antiserum (titre) was defined as that value of serum dilution that was required to obtain $50 \%$ of the maximum optical density in an ELISA of the antibody capture type (section 3.2.), as determined from a linear plot of optical density versus serum dilution (Fig. 3.6). Each antiserum has to be tested for its titre and should simultaneously be compared with pre-immune serum from the test animal itself or non-immune serum from the same species to determine background levels at a given dilution (Fig. 3.6). Titres of antisera from different test animals or test species can only be compared with each other when the assay conditions (e.g. amount of coated antigen and development time) are identical.

Titre measurements in the present study were carried out only to determine whether immunizations had been successful or not. Subsequent immunoassays were always carried out with purified IgG fractions (Chapter 2 section 7), labelled with HRP or unlabelled, extracted from antisera against human H-FABP.

\section{Rabbit antisera.}

Depending on the antiserum to be tested purified human H-FABP or one of the synthetic peptides (Chapter 2 section 5 and Chapter 3) was coated on 96-well polyvinylchloride microtiter plates by overnight incubation at $4^{\circ} \mathrm{C}$ in carbonate buffer ( $0.1 \mathrm{M}$, pH 9.6), or precoated plates (section 5) were used. Per well $200 \mathrm{ng}$ antigen in $50 \mu \mathrm{l}$ coating buffer was used. Subsequent washing and blocking was carried out with PBT [phosphate buffered saline (PBS) supplemented with $0.05 \%$ $(v / v)$ Tween-20 and $0.1 \%(w / v)$ bovine serum albumin (BSA)]. Serially diluted polyclonal antisera were incubated in the microtiter plates for 90 minutes at $20^{\circ} \mathrm{C}$. The plates were then washed and goat-anti-rabbit $\operatorname{Ig} G(\mathrm{H}+\mathrm{L})$, linked to horseradish peroxidase (GAR-PO), was added. Following $90 \mathrm{~min}$ incubation at $20^{\circ} \mathrm{C}$ the plates were washed again and developed with $100 \mu \mathrm{l}$ per well of a substrate-solution 
consisting of o-phenylene diamine (OPD, $10 \mathrm{mM})$ and $\mathrm{H}_{2} \mathrm{O}_{2}(8 \mathrm{mM})$, dissolved in $0.1 \mathrm{M}$ sodium citrate buffer ( $\mathrm{pH} 5.0$ ) (further named OPD $/ \mathrm{H}_{2} \mathrm{O}_{2}$-solution).

Development was stopped with $50 \mathrm{HI}_{4} \mathrm{~N} \mathrm{H}_{2} \mathrm{SO}_{4}$ per well, and extinction was read at $492 \mathrm{~nm}$ using a MkII Plus microplate reader (Flow Lab.).

Mouse sera against human H-FABP.

Similar procedures as for rabbit sera were followed in mice. Bound antibodies were detected with rabbit-anti-mouse $\operatorname{lgG}$ linked to horseradish peroxidase (RAMPO). After incubation and washing $100 \mu \mathrm{OPD} / \mathrm{H}_{2} \mathrm{O}_{2}$-solution was added, and subsequently the reaction was stopped with $50 \mu \mathrm{l} 4 \mathrm{~N} \mathrm{H}_{2} \mathrm{SO}_{4}$. Extinction was read at $492 \mathrm{~nm}$.

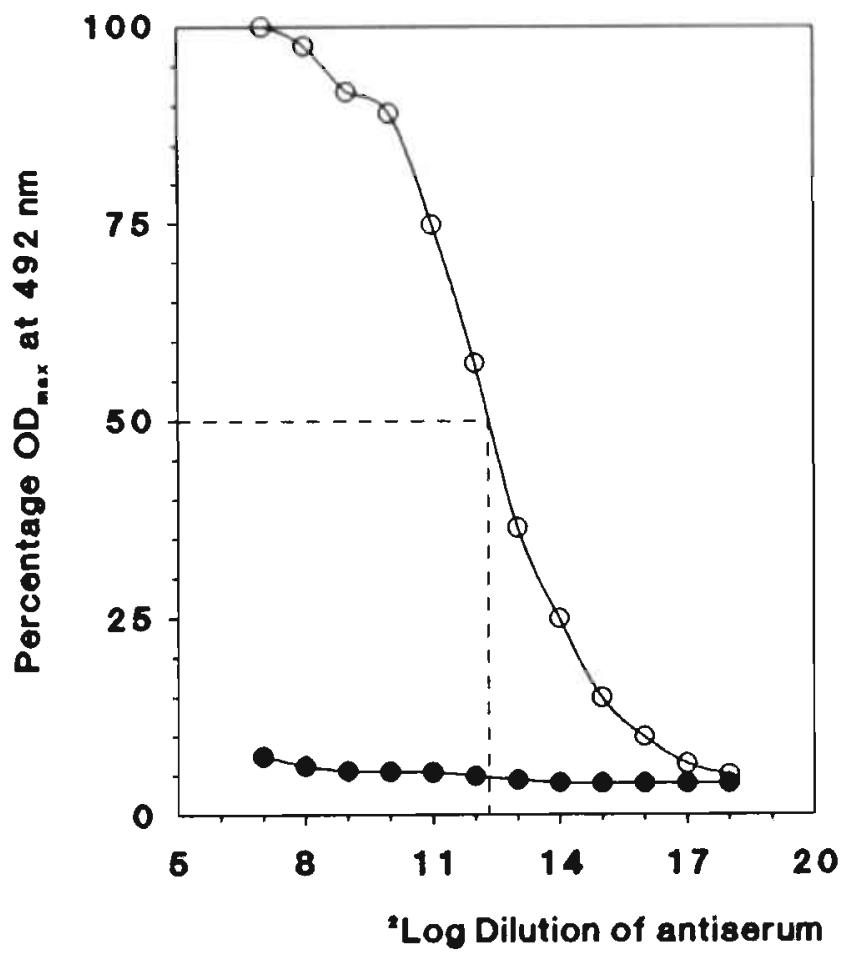

Figure 3.6. Example of antiserum titre determination using an ELISA of the antibody capture type. The percentage of maximal optical density (plateau value in antibody excess) is plotted against the assayed antiserum dilutions. Immune (open symbols) as well as pre-immune (closed symbols) serum was diluted according to a ${ }^{2} \mathrm{Log}$ scale. Optimal dilution (titre) is defined as the dilution at which $50 \%$ of the $O D_{\max }$ is reached (dotted lines). In the example the titre was determined to be 4900 .

\section{Mouse sera against synthetic peptides.}

Blocking and washing steps were performed with PBS supplemented with $0.1 \%(w / v)$ gelatin and with PBS, supplemented with $0.1 \%(w / v)$ gelatin and 
$0.05 \%(\mathrm{v} / \mathrm{v})$ Tween-20, respectively. Bound antibodies were detected with goatanti-mouse $\lg G$, linked to alkaline phosphatase, and subsequent development was carried out with substrate-solution, containing $0.1 \%(\mathrm{w} / \mathrm{v})$ p-nitrophenyl phosphate in $0.01 \mathrm{M}$ diethanol-amine and $0.01 \mathrm{M} \mathrm{MgCl}_{2}, \mathrm{pH} 9.8$. Extinction was read at 405 $\mathrm{nm}$.

\subsection{MEASUREMENT OF H-FABP IN HUMAN PLASMA SAMPLES.}

In order to accurately estimate H-FABP in plasma we developed a sensitive direct non-competitive sandwich ELISA essentially similar to that described by Börchers et al. [10] for the assay of H-FABP in subcellular fractions of bovine cardiac tissue. Our assay had to be more specific because, unlike subcellular tissue fractions, hunnan plasma contains a relatively large amount of proteins ( $c f$. albumin) in comparison to the amount of H-FABP present in blood. Thus, we developed an assay that would meet the requirements for measurement of minute amounts of human H-FABP in plasma samples.

The assay was carried out in Falcon 3912 Micro Test III polystyrene microtiter plates. Each well was coated with $200 \mathrm{ng}$ of monospecific polyclonal IgG against human H-FABP, isolated from rabbit immune serum (Chapter 2 section 7), in $50 \mu 1$ $0.1 \mathrm{M}$ ammonium carbonate ( $\mathrm{pH} 8.8$ ). Subsequently the wells were washed with PBT as described in section 5 of this chapter. Next the standards (see below) and plasma samples were incubated in the wells for 1.5 hours at room temperature. All plasma samples studied were serially diluted with PBT, so as to assure that their H-FABP content would fall within the linear part of the standard calibration curve. After washing with PBT the wells were incubated ( 1.5 hours at room temperature) with $70 \mathrm{ng}$ of monospecific polyclonal rabbit IgG-HRP conjugate (section 4) against human H-FABP in $50 \mu \mathrm{l}$ PBT for specific detection of bound FABP. Plates were developed with $100 \mu \mathrm{OPD} / \mathrm{H}_{2} \mathrm{O}_{2}$-solution per well. Development was stopped with $50 \mu \mathrm{l} 4 \mathrm{~N} \mathrm{H}_{2} \mathrm{SO}_{4}$ per well after 3-5 minutes and extinction was read at $492 \mathrm{~nm}$ using a MkII Plus microplate reader.

\section{Calibration of the assay.}

The calibration curve formed an integral part of each assay. The range for the calibration curve, 0 to $5 \mu \mathrm{g}$ purified human H-FABP (Chapter 2 section 3 ) per litre PBT (0 to $250 \mathrm{pg} /$ well), was chosen because preliminary experiments showed that the calibration curve levelled off around $500 \mathrm{pg} \mathrm{H-FABP}$ (data not shown). In the chosen range the calibration curve for the assay was found to be strictly linear (slope between 0.99 and 1.00; for a typical example see Fig. 3.7). For each assay the calibration curve was carried out in quadruplicate.

\section{Normal FABP concentrations in Control Human Plasma.}

Measurement of H-FABP content in human plasma of 72 healthy individuals revealed a normal plasma concentration of $9 \pm 5 \mu \mathrm{g} / \mathrm{l}$ (mean \pm S.D.). From this figure a reference value of $19 \mu \mathrm{g} / \mathrm{l}$ (mean $+2 \times$ S.D.) was calculated. After 
determination of the reference value equal aliquots of the 72 individual plasma samples were pooled to serve as a control human pool plasma for the remaining experiments.

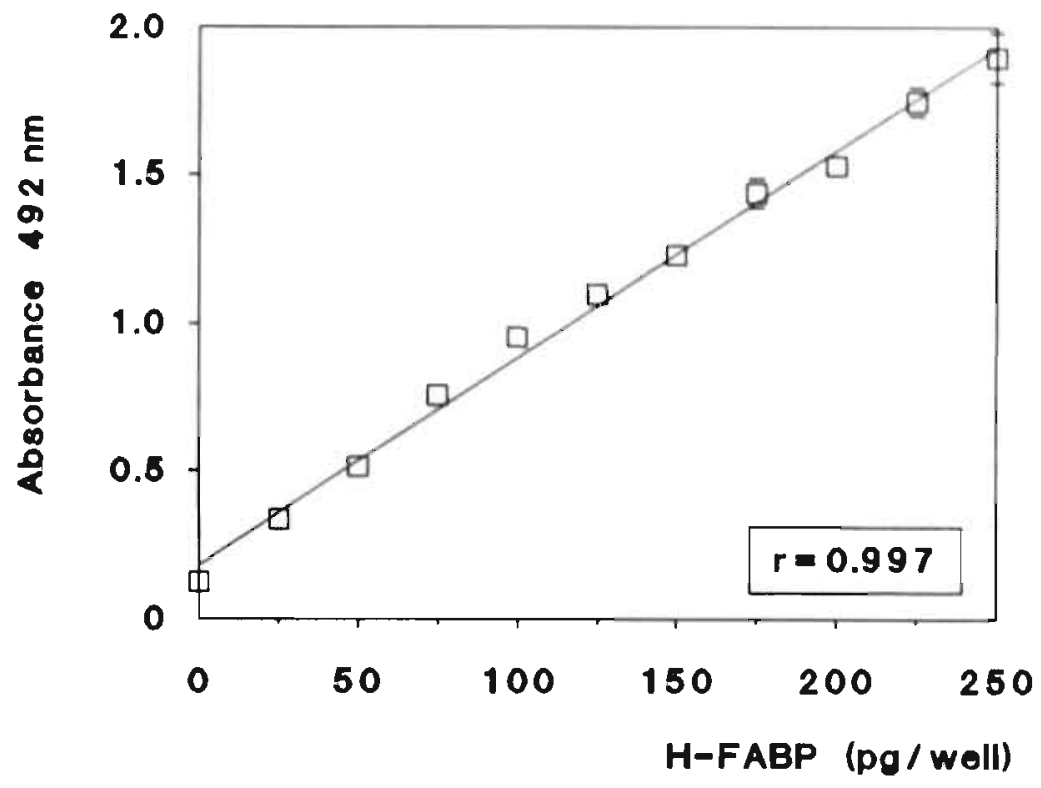

Figure 3.7. Standard calibration curve for the sandwich enzyme linked immunosorbent assay (sandwich ELISA). The immunoassay was carried out as described in section 3.6 .

\section{Recovery of spiked H-FABP.}

In the recovery experiments the control human pool plasma, spiked with 250 $\mu \mathrm{g}$ of purified H-FABP per litre, was used as stock solution. The spiked control human pool plasma was diluted with PBT to attain H-FABP concentrations of 5 , 2.5 and $1 \mu \mathrm{g}$ per litre of solution. $50 \mu \mathrm{l}$ samples of these solutions were measured in the sandwich ELISA. These recovery experiments yielded an overall recovery of added H-FABP of $93.2 \pm 12.4 \%$ (Table 3.1), which demonstrates the accuracy of the assay. The inter- and the intra-assay coefficients of variation were on the order of $7 \%$ respectively $4.5 \%$, as was calculated from repeated triplicate measurement $(n=$ 9) of a plasma sample from a control patient, demonstrating the reproducibility of the assay.

Because control human pool plasma samples could not be regarded as true zero samples since they contain H-FABP, samples of PBT (without H-FABP) were always included in the immunoassay to assess the nonspecific binding of the DeAbs to the matrix (assay background value). The assay background value was usually low, ranging between optical densities of 0.1 and 0.2 when measured at $492 \mathrm{~nm}$. 
Table 3.1. RECOVERY OF H-FABP ADDED to CONTROL. HUMAN POOL PLASMa (CHPP), USING A SANDWICH ELISA.

\begin{tabular}{ccc} 
H-FABP' $(\mathrm{pg} / \mu \mathrm{l})$ & Recovery of added H-FABP $(\%)$ & Overall recovery of added H-FABP $(\%)$ \\
\hline 50 & $92.8 \pm 15 \quad(n=17)$ & \\
100 & $93.8 \pm 12 \quad(n=11)$ & $93.2 \pm 12.4 \quad(n=63)$ \\
250 & $92.8 \pm 10.2(n=35)$ & \\
\hline
\end{tabular}

'Total amount of H-FABP present in the well during assay (see text for details).

All data are mean \pm SD for the number of experiments indicated in parentheses.

\subsection{REFERENCES.}

1. Harlow E, Lane D. In Antibodies (a laboratory manual), Chapter 9, Cold Spring Harbour Laboratory, Cold Spring Harbour, USA, pp. 321-358, 1988

2. Engvall E, PerImann P: Enzyme-linked immunosorbent assay (ELISA): quantitative assay of immunoglobulin G. Immunochemistry 8: 871-879, 1966

3. Nakane P, Pierce GB, Jr: Enzyme-labelJed antibodies: Preparations and applications for the localization of antigens. J Histochem Cytochem 14: 929-930, 1967

4. Van Weemen BK, Schuurs AHWM: Immunoassay using antigen-enzyme conjugates. FEBS Lett 15: 232-236, 1971

5. Harlow E, Lane D. In: Antibodies (a laboratory manual), Chapter 14, Cold Spring Harbour Laboratory, Cold Spring Harbour, USA, pp. 553-612, 1988

6. Farr AG, Nakane PK: Immunohistochemistry with enzyme labeled antibodies: A brief review. I Immunol Methods 47: 129-144, 1981

7. Avrameas S: Enzyme markers: Their linkage with proteins and use in immuno-histochemistry. Histochem / 4: 321-330, 1972

8. Tijssen $P$, Kurstak $E$ : Highly efficient and simple methods for the preparation of peroxidase and active peroxidase-antibody conjugates for enzyme immunoassays. Anal Biochem 136: 451-457, 1984

9. Voller A, Bidwell DE, Bartlett A: The Enzyme-linked Immunosorbent Assay (ELISA). Dynatech Europe, UK, 1979

10. Borrchers $T$, Unterberg $C$, Rüdel H, Robenek H, Spener F: Subcellular distribution of cardiac fatty acid-binding protein in bovine heart muscle and quantitation with an enzyme-linked immunosorbent assay. Biochim Biophys Acta 1002: 54-61, 1989 
CHAPTER 4

\section{TYPE-SPECIFIC IMMUNODETECTION OF HUMAN HEART FATTY ACID-BINDING PROTEIN WITH POLYCLONAL ANTIBODIES RAISED AGAINST H-FABP AND SYNTHETIC PEPTIDES*.}

4.1. Introduction $\mathrm{p} 48$

4.2. Materials and Methods p 48

4.3. Results p 50

4.4. Discussion p 52

4.5. Summary p 54

4.6. References p 54

Adapted from Kleine AH, Glatz JFC, van Nieuwenhoven FA, Vallinga MIJ, Salden MHL, Bosman FT, Boersma WJA, Zegers ND, van der Vusse GJ: Type-specific immunodetection of human heart fatty acid-binding protein with polyclonal antipeptide antibodies. Mol Cell Biochem 98: 41-48, 1990. 


\subsection{INTRODUCTION.}

As mentioned in Chapter 1 nowadays at least six distinct types of FABP are identified (Table 1.1). The three main types of FABP, namely heart (H-), liver (L-), and intestinal (I-)FABP show considerable differences in amino acid composition and primary structure (less than $30 \%$ sequence homology), resulting in a mutual cross-reactivity of polyclonal antisera raised against these FABP types of only 0-5\% $[1,2]$. The more recently detected types of FABP, i.e. adipose tissue (A-) [3], kidney (K-) $[4]$ and brain (B-)FABP [5], show a high degree of sequence homology, both mutually and with other types of FABP.

These common sequences can comprise of one or more immunodominant epitopes. Hence, when the FABP molecule as a whole is presented to the immune system as antigen, this can result in production of antibodies directed preferably against these immunodominant sites. As a consequence of this immunodominance [6] polyclonal antibodies raised against specific types of FABP are likely to show cross-reactivity with other types of FABP. Therefore, the type-specific immunochemical determination of FABPs in a mixture with other types is hampered. The problem of immunodominancy may be circumvented by presenting a small, typespecific part of the FABP molecule to the immune system, provided that this part bears appreciable antigenicity [7].

In order to develop type-specific antibodies to human H-FABP an antigenic index $[8,9]$ was computed to identify highly antigenic regions on the human $\mathrm{H}$ FABP molecule (see Chapter 2 section 5). Characteristic parts within these antigenic regions were synthesized and conjugates of synthetic peptide and a carrier protein (Keyhole Limpet Haemocyanin) were used for inoculation of rabbits and mice. Immunoreactivity and immunospecificity of the raised polyclonal antisera were tested in ELISA (see Chapter 3) as well as on tissue sections.

The results show that all selected synthetic peptides were immunogenic as well as antigenic, rendering antisera with a high titre and variable specificity. For those cases in which human H-FABP was recognized by the antibodies, the immunoreaction with the native protein was detected at even higher serum dilutions than with the synthetic peptide.

\subsection{Materials and Methods.}

\section{Peptide selection.}

Using a computed antigenic index according to Jameson and Wolf [8] and Wolf et al. [9] - which was based on the published amino acid sequence of human H-FABP [ref. 10, and Figure 2.5.] - four amino acid sequences were selected. The selected amino acid sequences included possible antigenic regions that scored 1.2 or higher on the antigenic index (see Figure 2.6.). Strongly homologous regions were avoided. This led to the synthesis of four peptides, designated SP1 (residues 10-25, KLVDSKNFDDYMKSLG), SP2 (residues 37-53, TKPTTIIEKNGDILTLK), SP3 (residues 97-112, QKWDGQETTKVRELID), and SP4 (residues 120-134, THGTAVSTRTYEKEA). Selected sequences showed no significant degree of homology with human L- 
FABP, human serum albumin, transferrin, and the constant regions of $\lg A 1, \lg$, and IgG subclasses.

\section{Synthetic peptides.}

Peptides (SP 1-4) were produced by solid-phase synthesis as described in Chapter 2 section 5 .

\section{Isolation and purification of FABP.}

Human H-FABP was isolated from human myocardial tissue obtained within 12 hours post mortem. Isolation and purification procedures are described in Chapter 2 section 2.

\section{Preparation of antibodies.}

For each peptide two rabbits (Flemish giant) were immunized and boosted 4 weeks later with KLH-SP conjugate in a mixture of PBS and Freund's Complete Adjuvant (FCA). In addition, two rabbits were immunized and boosted with human H-FABP. Boosting was repeated in week 8 (second boosting) with Freund's Incomplete Adjuvant (FIA) instead of FCA.

Four groups of four female mice $(\mathrm{Balb} / \mathrm{C})$ were immunized intraperitoneally with antigen (human H-FABP or KLH-SP conjugates) in an PBS/oil-emulsion [11]. The same emulsion was used four and eight weeks later for the first and the second booster, respectively. The results discussed in this chapter were obtained with the sera collected from rabbits and mice two weeks after the second booster. For more details about preparation of antibodies see Chapter 2 section 6 .

\section{Enzyme linked immunosorbent assay (ELISA).}

Rabbit sera: Antigen (human H-FABP or SP1-4) was coated on 96-well polyvinylchloride microtiter plates by overnight incubation at $4^{\circ} \mathrm{C}$ in $0.1 \mathrm{M}$ carbonate buffer, $\mathrm{pH}$ 9.6. The subsequent washing and blocking was carried out with PBS, supplemented with $0.05 \%(\mathrm{v} / \mathrm{v})$ Tween-20 and $0.1 \%(\mathrm{w} / \mathrm{v})$ bovine serum albumin. Serially diluted polyclonal antisera were incubated in the microtiter plates for 90 minutes at $20^{\circ} \mathrm{C}$. The plates were then washed and goat-anti-rabbit IgG, linked to horseradish peroxidase, was added. Following $90 \mathrm{~min}$ incubation at $20^{\circ} \mathrm{C}$ the plates were washed again and developed with substrate-solution, containing $0.04 \%(w / v)$ o-phenylene diamine and $0.0015 \%(\mathrm{v} / \mathrm{v}) \mathrm{H}_{2} \mathrm{O}_{2}$. Development was stopped with $4 \mathrm{~N}$ $\mathrm{H}_{2} \mathrm{SO}_{4}$ and extinction was read at $492 \mathrm{~nm}$.

Mouse sera: Similar procedures as for rabbit sera were followed, except for the blocking and washing steps, which were carried out with PBS, supplemented with $0.1 \%(w / v)$ gelatin and with PBS, supplemented with $0.1 \%(w / v)$ gelatin and $0.05 \%(v / v)$ Tween-20, respectively. Bound antibodies were detected with goatanti-mouse $\mathrm{IgG}$, linked to alkaline phosphatase, and subsequent development was carried out with substrate-solution, containing $0.1 \%(w / v)$ p-nitrophenyl phosphate in $0.01 \mathrm{M}$ diethanol-amine and $0.01 \mathrm{M} \mathrm{MgCl}_{2}, \mathrm{pH} 9.8$. Extinction was read at $405 \mathrm{~nm}$. 


\section{Immunohistochemistry.}

Frozen as well as paraffin embedded tissue sections ( $4 \mu \mathrm{m}$ in thickness) of human heart muscle, psoas muscle, liver, and duodenum (frozen tissue only) were used. Prior to embedding in paraffin tissues were fixed by immersion in buffered formalin [4\%, v/v, pH 7.0)], for at least 24 hours. Frozen tissue sections were fixed by exposure (10 $\mathrm{min}$ ) to paraformaldehyde-vapour in a dessicator under light vacuum, or by submersion in cold $\left(-20^{\circ} \mathrm{C}\right)$ acetone for $20 \mathrm{~min}$. Staining results with either fixation method showed no appreciable differences.

All antisera were used in a 1:500 dilution in PBS, supplemented with $0.1 \%(\mathrm{w} / \mathrm{v})$ bovine serum albumin. Bound rabbit-and mice-antibodies were detected with goat-anti-rabbit IgG and rabbit-anti-mouse Ig, respectively, conjugated with horseradish peroxidase. Diaminobenzidine was used as chromogen. Tissue sections were counterstained with haematoxylin.

\subsection{Results.}

\section{Immunohistochemical studies.}

Cross-reactivity of the raised antisera with other FABP types was studied immunohistochemically on frozen and paraffin sections of various human tissues. With rabbit antisera the results on paraffin sections were comparable to those on frozen sections of the same tissues. Cytoplasmatic staining of myocardial myocytes was observed with the rabbit antisera RaHFABP, RaSP1, and RaSP2. M. psoas and $\mathrm{m}$. mucosae myocytes and hepatocytes remained unstained when the latter three antisera were used. Antisera RaSP3 and RaSP4 did not stain any of the cell types studied, including cardiomyocytes.

Mouse sera, even at antiserum dilutions as low as 1:100, failed to stain (frozen or paraffin embedded) sections of human myocardium, liver, psoas muscle, or duodenum (Data of the immunohistochemical studies are not shown).

\section{Analysis of anti-peptide antibody response in ELISA.}

In all rabbits inoculation and subsequent boosting with KLH-SP-conjugates evoked an immunoresponse, rendering anti-SP antisera (RaSP) that reacted strongly with the specific synthetic peptide (Fig. 4.1.). Antisera against three of the four peptides could also recognize the native protein, human H-FABP. Peptide antiserum RaSP2 was found to react even stronger with human H-FABP than with its immunogen. RaSP3 and RaSP4 showed a strong crossreaction with their mutual antigens. However, the reaction of RaSP3 with human H-FABP is negligible. Surprisingly, rabbit antisera raised against purified human H-FABP (RaHFABP), showed no or hardly any cross-reactivity with any of the free synthetic peptides (a typical example is shown in Fig. 4.2.).

In mice only two of the four anti-SP antisera (MaSP) showed anti-SP-specific immunoreaction when tested in ELISA (MaSP1 and MaSP4 in Fig. 4.1.). Only one of these (MaSP1) also showed a reaction with the native protein (Fig. 4.1.). 
Polyclonal antisera raised against purified human H-FABP in mice (MaHFABP) showed high antibody titers against the native protein, but no immunoreactivity with the synthetic peptides (Fig. 4.2.). Control sera, i.e. normal rabbit and mice sera, showed no immunoreaction (Fig. 4.1.).

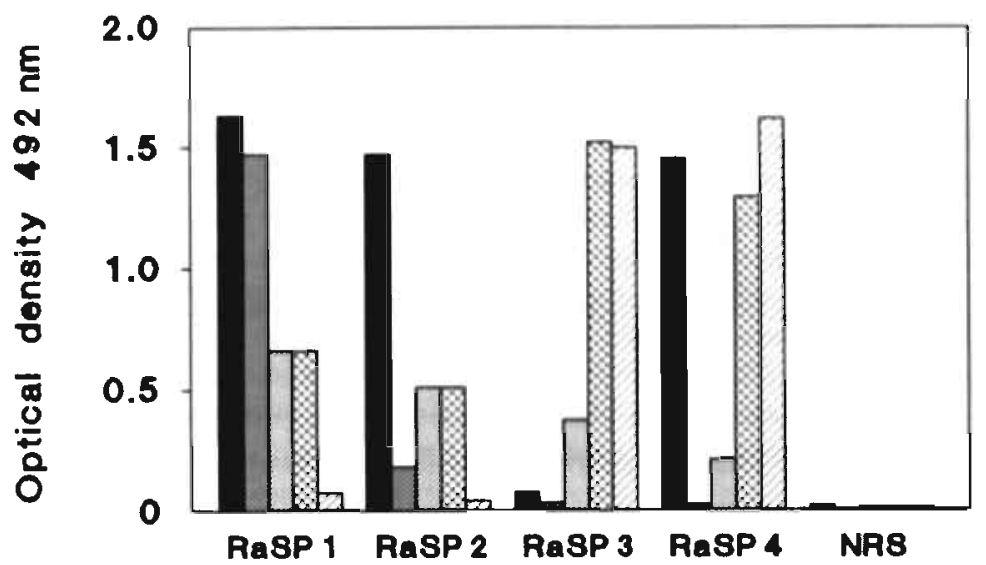

Rabbit antisera

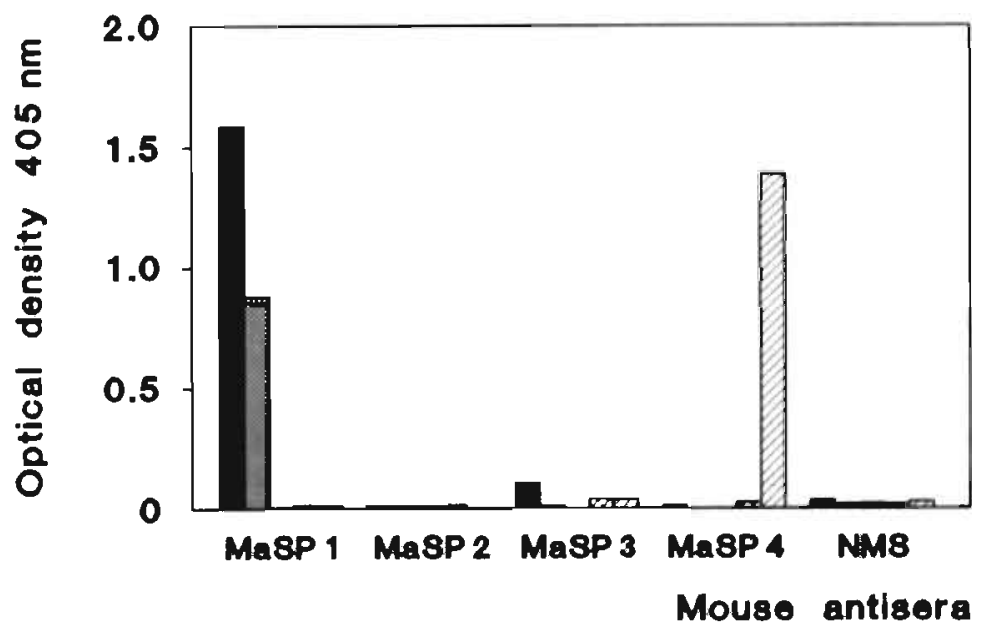

Antigen: $\square$ H-FABP $\square$ SP $1 \square$ SP $2 \square$ 8P $3 \square$ 8P 4

Figure 4.1. Specificity of polyclonal rabbit (upper panel) and mice (lower panel) antisera raised against the synthetic peptides SP1 to SP4 (RaSP's and MaSP's, respectively) tested in ELISA for their reaction with the native protein (human H-FABP), and with the four synthetic peptides. Results are shown of typical experiments with sera from one rabbit per peptide and of mean values obtained with sera of four mice per peptide (differences among individual mice were less than 10\%). Normal rabbit serum (NRS) and normal mouse serum (NMS) were used as negative controls. Serum dílution was 1:1000 (rabbits) or 1:400 (mice). 


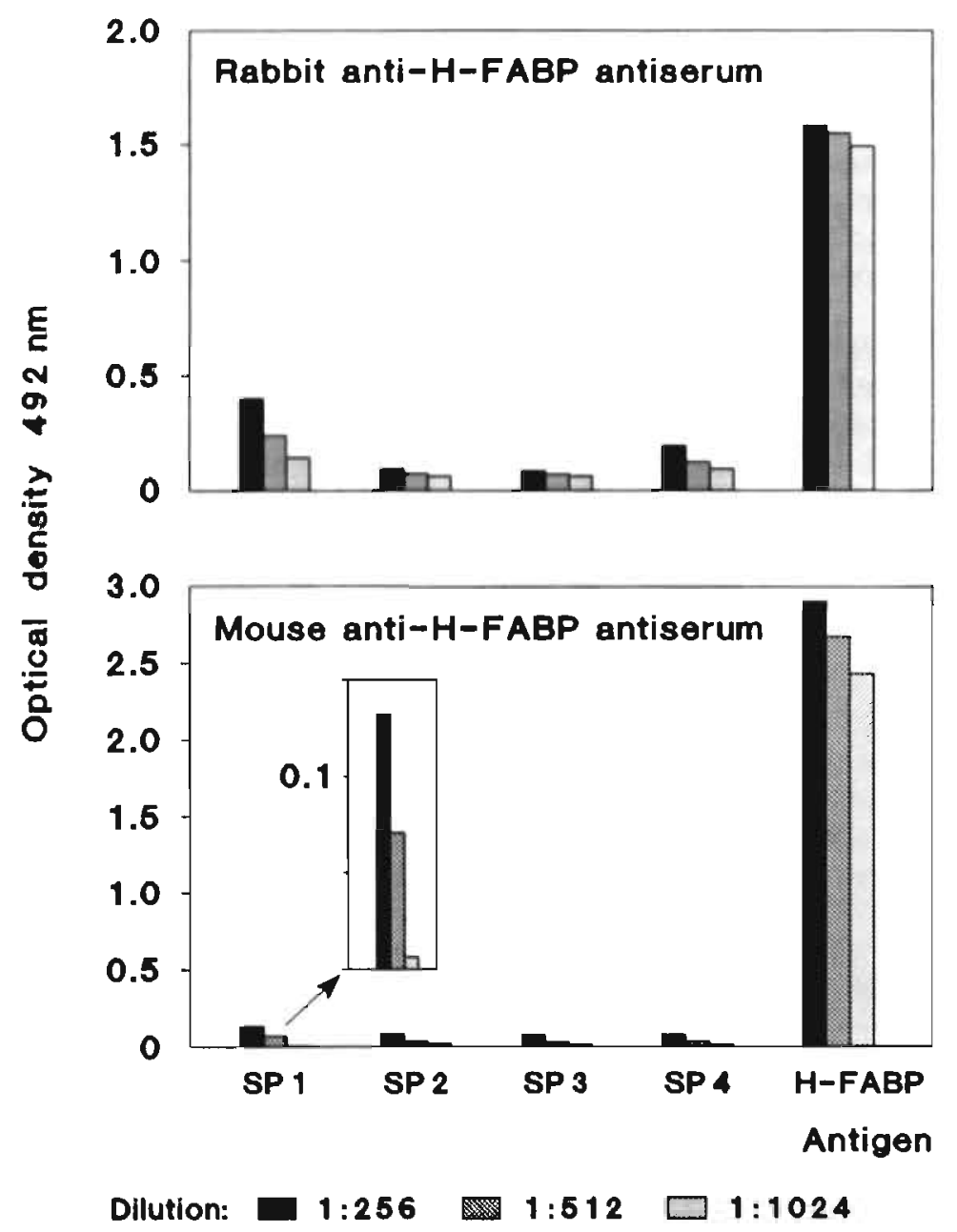

Figure 4.2. Immunoreactivity, at different dilutions, of polyclonal rabbit (upper panel) or mice (lower panel) anti-human H-FABP antisera tested in ELISA on human H-FABP and the synthetic peptides SP1 to SP4. Results are shown of typical experiments with serum from one rabbit and of mean values obtained with sera of three mice (differences among individual mice were less than 10\%). Immunoreaction of mouse anti-H-FABP antiserum with SP1 (insert in lower panel) is representative for the reaction of this anti-serum with the other SP's.

\subsection{DisCusSion.}

Peptides representing unique amino acid sequences which have a high score on the antigenic index were used as specific antigenic determinants for the human H-FABP. Four peptides were selected for synthesis on the basis of a Jameson and Wolf prediction [8]. The synthetic peptides were used for the generation of poly- 
clonal antisera in rabbits and mice. In rabbits each of the selected peptides proved to be immunogenic and antigenic. Three out of four specific polyclonal rabbit antisera also recognized the native protein (H-FABP). In mice only two out of four peptides were both immunogenic and antigenic. The specific polyclonal antiserum raised against one of these also recognized H-FABP. Immunohistochemistry showed that only the cytoplasm of cardiomyocytes was stained, and that only two of the four specific polyclonal rabbit antisera were able to do so. None of the specific polyclonal mice antisera were able to stain any of the studied cell types.

The antibodies of one of the rabbit antisera, RaSP3, did recognize the free oligopeptide (SP3) but not its equivalent in the native protein, either in the ELISA assay or in tissue sections of human myocardium. This finding suggests that conformational difference exists between the free oligopeptide SP3 on the one hand and the sequence of this peptide in the native protein on the other.

Taken together, the results of the ELISA and the immunohistochemical experiments suggest that the synthetic peptides SP1 and SP2, and their equivalents in the native FABP molecule, are stable and easily recognized structures.

Antibodies in the RaSP4 antiserum recognize the native protein in ELISA but, under the present conditions, not in tissue sections of human myocardium. The latter may have been caused by slight denaturation of human H-FABP during fixation of the tissues preceding the immunohistochemistry. The use of milder fixatives for immunohistochemistry is under consideration, although this could lead to elution of cytoplasmatic FABP during preparation of the tissues. As expected, none of the studied antisera crossreacted with proteins in tissue sections of human liver.

Only two groups of mice generated antisera which reacted with the immunizing synthetic peptide and, of these, MaSP1 also reacted with the native protein. The polyclonal antiserum raised against SP4 only reacted with the free oligopeptide SP4. Of the tested synthetic peptides only SP1 and SP4 seem to be immunogenic in the immune system of mice and antigenic for the generated antibodies. SP2 and SP3 fail to be immunogenic in the immune system of mice, in the form of a KLH-SP conjugate, or to be antigenic at all, in the form of a free oligopeptide.

The finding that polyclonal rabbit and mice antisera, raised against purified human H-FABP, show no immunoreactivity in ELISA with any of the synthetic peptides suggests that at least one region on the human H-FABP molecule is more immunogenic than the regions defined by the amino acid sequences of the used synthetic peptides. Apparently, this unidentified immunogenic region was not distilled from the Jameson and Wolf [8] prediction data. The latter can be explained by the fact that the Jameson and Wolf approach predicts antigenicity on the basis of the amino acid sequence of the peptide and the properties of its individual amino acids, thus predicting only linear determinants. Structural determinants or discontinuous epitopes, e.g. immunogenic and antigenic sites that bridge a gap or a turn in the amino acid chain, can not be predicted using this technique. Because the synthetic oligopeptides used in our experiments mutually have only two pairs of adjacent amino acids in common at the most, cross-reactivity of an antiserum raised against one of the used synthetic oligopeptides with one of the other selected oligopeptides (cf. RaSP3 and RaSP4) may indicate that antibodies not only 
recognize specific amino acid sequences but also certain tertiary structures in a protein [12]. On the other hand, polyclonal sera contain various antibodies which will have a broad affinity range for recognition of the peptides and the native protein. Furthermore, some of the antibodies may recognize one peptide whereas the other peptide is recognized by different antibodies.

It turned out that non of the synthetic peptides were useable in a sandwich ELISA (see Chapter 6 section 2) for measurement of H-FABP in biological preparations, either in combination with a second synthetic peptide or with antisera against the whole human H-FABP molecule. So in our case the followed routine for synthesizing peptides from human $\mathrm{H}-\mathrm{FABP}$ and subsequent raising of antibodies against those synthetic peptides did not result in antibodies we needed for our application. The question whether or not this failure was due to the antigenic mapping of the human H-FABP molecule according to Jameson and Wolf [8], or to the fact that antibodies against synthetic peptides were used in combination with each other or with antisera against the native protein remained unsolved during the experimental period. The study on the use of antibodies against synthetic peptides for measurement of human H-FABP was not continued after the aforesaid results. Nevertheless, it is expected that the polyclonal rabbit antisera raised against the peptides SP1, SP2, SP3 or SP4, preferably in combination with a monoclonal antibody directed against an antigenic site of the native protein not recognized by the polyclonal antisera, can be used for detection of the native protein in biological preparations by means of a capture-ELISA.

\subsection{SUMMARY.}

Generally, polyclonal antibodies against synthetic peptides can be applied for the specific detection of the native protein in biological preparations containing other proteins that show a high degree of homology with the protein to be assayed. Therefore, in order to develop specific antibodies against human heart cytoplasmatic fatty acid-binding protein (H-FABP), four oligo-peptides of 15-20 aminoacids each and corresponding with different antigenic parts of the human H-FABP molecule, were synthesized. Polyclonal antibodies against these synthetic peptides were raised in mice (Balb/C) and rabbits (Flemish giant). When tested in enzyme linked immunosorbent assays (ELISA, antibody-capture assay), antisera against three of the four peptides showed a high immunoreactivity with the synthetic peptide selected for immunization as well as with the native human H-FABP. Some cross-reactivity with the other synthetic peptides was observed for the rabbit antisera but not for those from mice. Under the present conditions, the antibodies raised against the synthetic peptides $\mathrm{SP} 1-4$ proved not be suitable for use in a sandwich ELISA for the measurement of human H-FABP in biological preparations. 


\subsection{REFERENCES.}

1. Bass NM, Manning JA: Tissue expression of three structurally different fatty acid binding proteins. from rat heart muscle, liver, and intestine. Biochem Biophys Res Comm 137: 929-935, 1986.

2. Paulussen RJA, Geelen M/H, Beynen AC, Veerkamp JH: Immunochemical quantitation of fattyacid-binding proteins. I. Tissue and intracellular distribution, postnatal development and influence of physiological conditions on rat heart and liver FABP. Biochim Biophys Acta 1001: 201-209, 1989.

3. Matarese V, Bernlohr DA: Purification of murine adipocyte lipid-binding protein. / Biol Chem 263 : 14544-14551, 1988.

4. Lam KT, Borkan S, Claffey KP, Schwartz JH, Chobanian AV, Brecher P. Properties and differential regulation of two fatty acid-binding proteins in the rat kidney. I Biol Chem 263: 15762-15768, 1988.

5. Schoentgen F. Pignede G, Bonanno LM Jollès P. Fatty-acid-binding protein from bovine brain. Amino acid sequence and some properties. Eur / Biochem 185 35-40, 1989.

6. Boersma WJA, Claassen E, Deen C, Gerritse K, Haaijman JJ, Zegers ND: Antibodies to short synthetic peptides for specific recognition of partly denatured protein. Anal Chim Acta 213: 187-197', 1988.

7. Alexander HD, Johnson DA, Rosen J, Jerabek L, Green N, Weissman IL, Lemer RA: Mimicking the alloantigenicity of proteins with chemically synthesized peptides differing in single amino acids. Nature (London) 306: 697-699, 1983.

8. Jameson BA, Wolf $\mathrm{H}$ : The antigenic index: a novel algorithm for predicting antigenic determinanis Cabios 4: 181-186, 1988.

9. Wolf H, Modrow S, Motz M, Jameson BA, Hermann C., Fortsch B: An integrated family of amino acid sequence analysis programs. Cabios 4: 187-191, 1988.

10. Offner GD, Brecher $P$, Sawlivich WB, Costello CE, Troxler RF: Characterization and amino acid sequence of a fatty acid-binding protein from human heart. Biochem / 252: 191-198, 1988.

11. Bokhout BA, Van Gaalen C, Van der Heijden J: A selected water-in-oil emulsion:Composition and usefulness as an immunological adjuvant. Vet Immunol Immunopathol 2: 491-500, 1981.

12. Lemer RA: Antibodies of predetermined specificity in biology and medicine. Adv Immunol 36: 1-44, 1984. 
CHAPTER 5

PLASMA CONCENTRATIONS OF CYTOPLASMATIC FATTY ACID-BINDING PROTEIN (FABP) AFTER CARDIAC MUSCLE TISSUE DAMAGE IN MAN*.

5.1. Introduction p 58

5.2. Material and methods p 58

5.3. Results $\mathrm{p} 61$

5.4. Discussion $\mathrm{p} 65$

5.5. Summary $\mathrm{p} 67$

5.6. References $p 68$

Adapted from Kleine AH, Glatz JFC, Van Nieuwenhoven FA, Van der Vusse G): Release of heart fatty acid-binding protein into plasma after acute myocardial infarction in man. Mol Cell Biochem 116: 155-162, 1992. 


\subsection{Introduction.}

Cytoplasmatic fatty acid-binding protein (FABP) is one of the most abundant cytoplasmatic proteins in the heart. In human and rat heart it comprises about 10 and $20 \%$, respectively, of the number of protein molecules present in the aqueous cytoplasm [1]. In a human heart this amounts to $0.5 \mathrm{mg}$ of FABP per gram wet weight (Table 6.1.). Previously, heart-type fatty acid-binding protein (H-FABP) has been shown to be released from isolated rat hearts upon cellular injury at a rate and to an extent similar to that of lactate dehydrogenase (LDH) [2]. The in vivo release of H-FABP from myocardial tissue upon cellular damage has subsequently been demonstrated immunochemically in rats, using polyclonal as well as monoclonal mouse antibodies against rat H-FABP [3], and in cardiac patients using monoclonal mouse antibodies against rabbit H-FABP [4]. Tanaka et al. [5], using anti-human H-FABP antibodies in a competitive enzyme immunoassay, also showed elevated serum concentrations of FABP after acute myocardial infarction in man. These findings suggest that in cardiac patients the plasma FABP concentration can be used as an indicator for damage of myocardial tissue. The above observations warranted further investigations on the usefulness of plasma FABP concentration for the (early) assessment of an acute myocardial infarction (AMI) in man. Therefore, results of measurements of FABP content in plasma, using an enzyme immunoassay of the sandwich type (Chapter 3, section 6) are presented in this Chapter. Plasma FABP concentrations of cardiac patients were compared with plasma activity values of the myocardial cytoplasmatic enzymes creatine kinase $\mathrm{MB}(\mathrm{CK}-\mathrm{MB})$ and alpha-hydroxybutyrate dehydrogenase $(\alpha-$ $\mathrm{HBDH})$, and with plasma concentrations of myoglobin. Myoglobin was chosen for comparison because this oxygen-carrying protein inside muscle cells has also been introduced as a plasma marker for early indexation and quantification of acute myocardial infarction [6-13]. Measurements of FABP, CK-MB and $\alpha-\mathrm{HBDH}$ were made in serial plasma samples obtained from 26 patients with initial clinical diagnosis of AMI, while myoglobin was also measured in plasma from 10 out of the 26 patients. Concentrations of the specific proteins (except myoglobin), as determined in non-haemolytic plasma from 72 healthy individuals, served as reference values. For myoglobin the assay detection limit of $50 \mu \mathrm{g} / \mathrm{l}$ served as the threshold limit for myoglobin.

\subsection{MATERials AND Methods.}

\section{Patients.}

The initial clinical diagnosis of all 26 patients included in this study was acute myocardial infarction (AMI). AMI was positively diagnosed when patients showed elevation of more than one millimetre of the ST-segment in the recorded electrocardiogram and presentation of typical chest pain (often combined with radiation of pain to the left arm), in combination with transpiration, nausea, and/or shortness of breath. Diagnosis of AMI was confirmed by data on enzyme release (i.e. significant rise in $\mathrm{LDH}, \mathrm{CK}$ and $\alpha-\mathrm{HBDH}$ activity within 8 hours after onset of 
first symptoms) in 22 patients, the remaining 4 patients were diagnosed havingr unstable angina pectoris.

\section{Blood sampling.}

Blood samples were collected in glass tubes coated with ethylenediaminetetraacetic acid (EDTA) and subsequently spun for 10 minutes at $1500 \times \mathrm{g}$. The resulting supernatant plasma was divided into several aliquots in glass tubes. Samples were stored at $-80^{\circ} \mathrm{C}$ until further use. Starting from admission of the patients to the coronary care unit of the hospital (Academic Hospital "Maastricht, head of the unit: Dr. $\bar{C}$. de Zwaan) blood samples were taken based on a time schedule of $0,4,10,18,28$ and 38 hours from admission (hospital routine). $A$ subgroup of ten patients was sampled hourly during the first ten hours of hospitalization. Thereafter blood samples were again taken in accordance with hospital routine up to 38 hours after admission, together resulting in 11-14 blood samples per patient in this subgroup.

Non-haemolytic blood samples of healthy individuals $(n=72)$, collected at the local bloodbank, were used for the assessment of the reference (= upper normal) values in plasma of FABP, CK-MB and $\alpha-\mathrm{HBDH}$.

\section{Sandwich ELISA.}

A direct non-competitive Enzyme Linked Immunosorbent Assay of the antigen capture type (sandwich ELISA) was used to measure H-FABP concentrations in human plasma and in myocardial tissue samples. The reader may find the description of this assay in Chapter 3, section 6. The isolation and purification of human H-FABP, the subsequent production of antisera against human H-FABP and the isolation of monospecific IgG against human H-FABP from the antisera are described in Chapter 2, sections 2, 6 and 7, respectively.

\section{Measurement of myoglobin plasma concentrations.}

In the subgroup of ten frequently sampled patients the myoglobin concentration in the plasma samples was measured according to the method described in Chapter 2, section 10.

\section{Measurement of CK-MB and $\alpha-H B D H$ activity.}

Activity of $\mathrm{CK}-\mathrm{MB}$ was measured by an enzyme immunoinhibition assay kit. Activity of $\alpha-\mathrm{HBDH}$, which is predominantly LDH-isoenzyme-1, was measured spectrophoto-metrically with $\alpha$-ketobutyrate as the substrate [14] using a commercially available test kit (see Chapter 2 , section 11). 

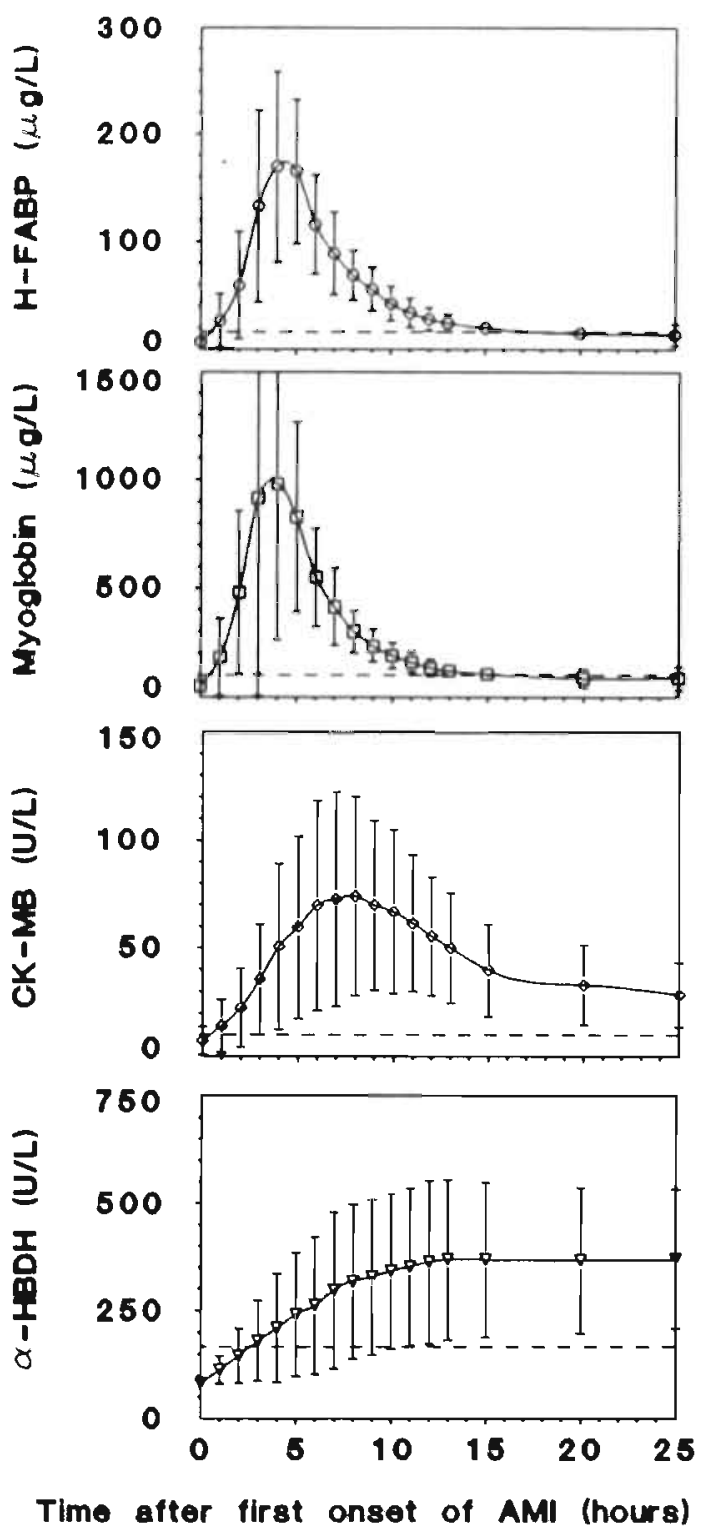

Figure 5.1. Mean plasma time-concentrations curves of H-FABP and myoglobin and plasma timeactivity curves of $\mathrm{CK}-\mathrm{MB}$ and $\alpha-\mathrm{HBDH}$ after acute myocardial infarction $(n=8)$. Dotted lines indicate reference values of $\mathrm{H}-\mathrm{FABP}, \mathrm{CK}-\mathrm{MB}$ and $\alpha-\mathrm{HBDH}$ in normal human plasma, and assay detection limit for myoglobin (see text for details). 


\subsection{RESULTS.}

\section{Reference values.}

In this study the reference value is defined as the mean value plus twice the standard deviation of the particular protein, as measured in normal human plasma [15]. The plasma concentrations (mean \pm SD), measured in 72 healthy volunteers (blood donors), were calculated to amount to $9 \pm 5 \mu \mathrm{g} / \mathrm{l}$ for $\mathrm{H}-\mathrm{FABP}, 4 \pm 3 \mathrm{U} / \mathrm{i}$ for $\mathrm{CK}-\mathrm{MB}$, and $90 \pm 35 \mathrm{U} / \mathrm{l}$ for $\alpha-\mathrm{HBDH}$. Thus, the plasma reference value for $\mathrm{H}$ FABP, CK-MB, and $\alpha-\mathrm{HBDH}$ were calculated to be $19 \mu \mathrm{g} / 1,10 \mathrm{U} / \mathrm{l}$, and $160 \mathrm{U} / \mathrm{l}$, respectively.

For myoglobin the assay detection limit of $50 \mu \mathrm{g} / \mathrm{l}$ was also used as reference value because this value is close to the normal plasma concentration of myoglobin (31 $\pm 15 \mu \mathrm{g} / \mathrm{l}$; mean $\pm \mathrm{SD}, \mathrm{n}=135$ ) as found by Stone $\mathrm{et}$ al. [6].

\section{Plasma curies.}

In Figure 5.1. the mean plasma curves for H-FABP, myoglobin, CK-MB and $\alpha$ HBDH of 8 of the 10 frequently sampled cardiac patients are presented. The remaining two patients will be discussed below. The plasma concentrations of $\mathbf{H}$ FABP, myoglobin, $\mathrm{CK}-\mathrm{MB}$, and $\alpha-\mathrm{HBDH}$ peaked at $4.2 \pm 0.8$ hours, $4.2 \pm 0.8$ hours, $9.3 \pm 1.7$ hours and $24.3 \pm 10.2$ hours (mean $\pm S D, n=8$ ), respectively, after the onset of the first symptoms. In general, relatively high plasma FABP and myoglobin concentrations in blood samples taken early are followed by relatively high concentrations of CK-MB and $\alpha-\mathrm{HBDH}$ in the blood samples taken later (Fig. 5.1.). From the aforesaid subgroup of 10 frequently sampled patients data from two patients were not used for Figure 5.1. because their release curves were aberrant. In one case (Fig. 5.2.) this was due to defibrillation during hospitalization, causing a prolonged high plasma concentration of myoglobin, while the plasma concentrations of FABP and the activity plasma values of CK-MB and $\alpha-\mathrm{HBDH}$ showed minor effects. In the other case the aberrance was caused by severe renal insufficiency (Fig. 5.3.). The first blood sample was normal. Thereafter this patient showed a heightened ( 4 to 8 times the reference value) FABP plasma concentration and a heightened myoglobin plasma concentration during the whole course of the sampling time. The CK-MB plasma concentration in this case was only elevated about 1.5 times the reference value during a short period of the sampling time, while the $\alpha-\mathrm{HBDH}$ plasma concentration stayed normal during sampling time (Fig. 5.3.).

The release curves for all 26 patients studied revealed that within 20 hours after the onset of the first symptoms of AMI, plasma FABP concentrations had returned to the threshold values (cf. Fig. 5.1.). The plasma myoglobin concentrations in 8 of the 10 frequently sampled patients had also returned to the threshold value within 20 hours after the onset of first symptoms of AMI (Fig. 5.1.). In contrast, plasma activities of CK-MB and $\alpha-\mathrm{HBDH}$ in all 26 patients studied remained well above the threshold value until at least 25 hours after the onset of the first symptoms. 

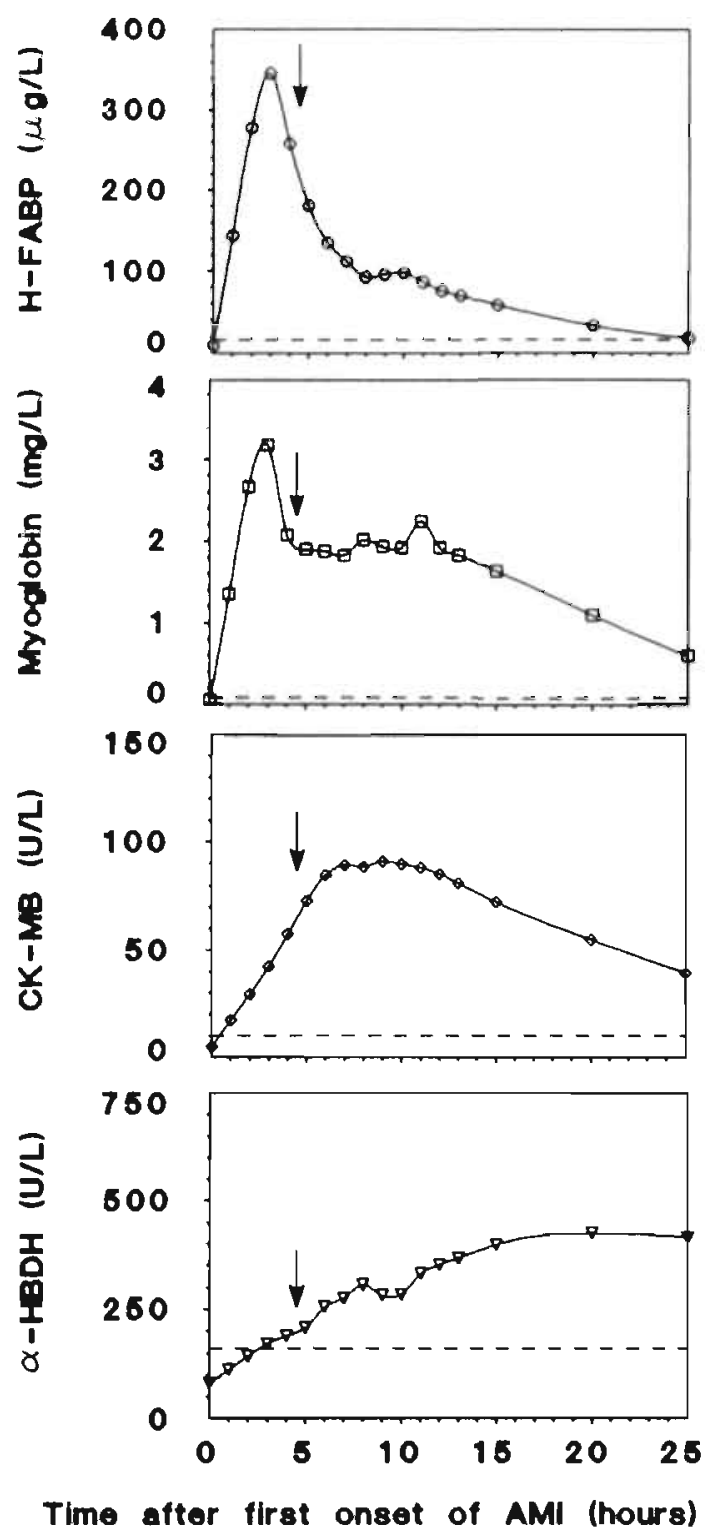

Figure 5.2. Plasma concentrations of H-FABP and myoglobin and plasma activity values of CK-MB and $\alpha-H B D H$ in a patient who underwent cardioversion (defibrillation) around 4 hours after the first onset of symptoms (see arrows), during 25 hours after the first onset of symptoms. Dotted lines indicate reference values of $\mathrm{H}-\mathrm{FABP}, \mathrm{CK}-\mathrm{MB}$ and $\alpha-\mathrm{HBDH}$ in normal human plasma, and assay detection limit for myoglobin (see text for details). 

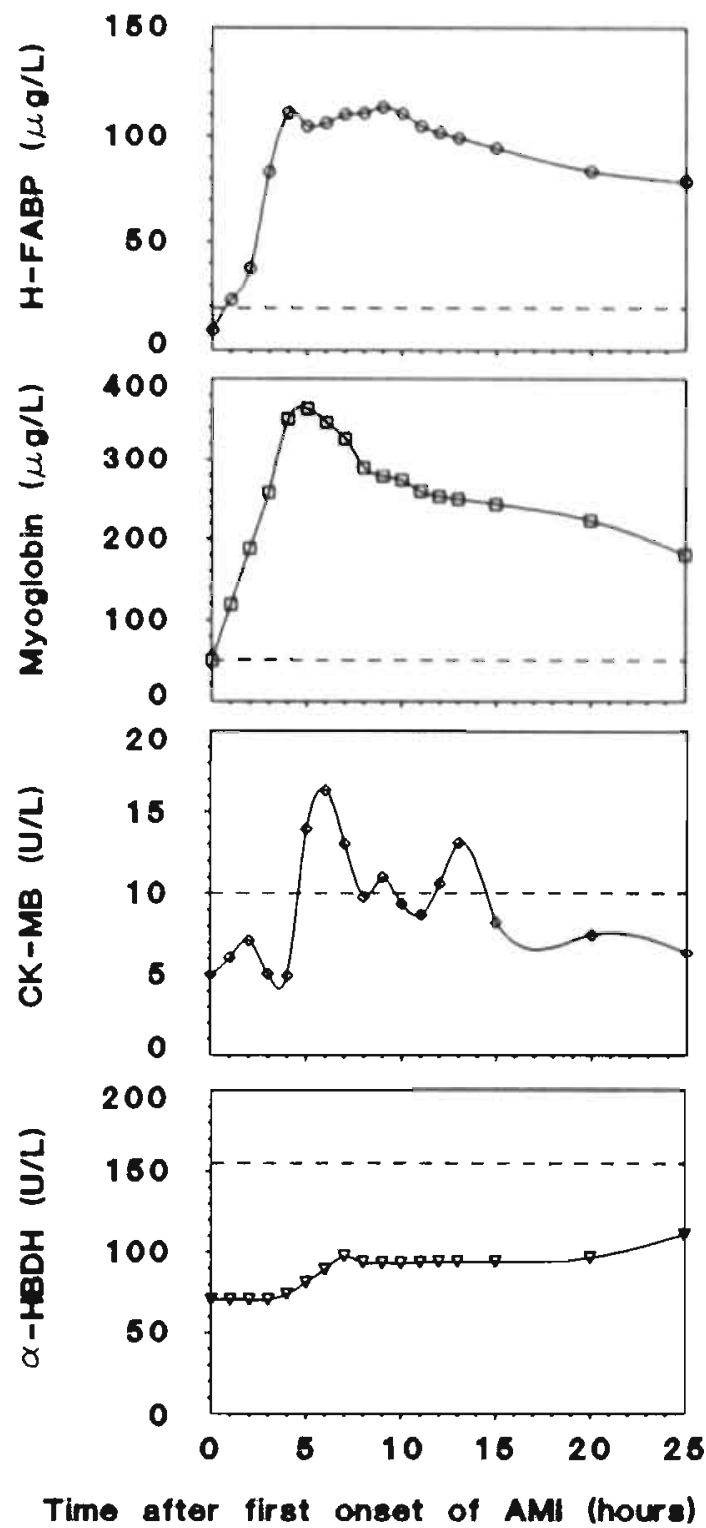

Figure 5.3. Plasma concentrations of H-FABP and myoglobin and plasma activity values of CK-MB and $\alpha-\mathrm{HBDH}$ in a patient with inferior myocardial infarction in combination with instable angina pectoris and severe renal insufficiency, during 25 hours after the first onset of symptoms. Dotted lines indicate reference values of H-FABP, CK-MB and $\alpha-\mathrm{HBDH}$ in normal human plasma, and assay detection limit for myoglobin (see text for details). 
Since the plasma FABP and myoglobin concentrations had returned to their respective threshold values within 25 hours after first onset of AMI only the data up to 25 hours after first onset of AMI are presented in the figures.

\section{Early diagnosis of AMI.}

In Figure 5.4. the FABP concentration and the CK-MB and $\alpha-\mathrm{HBDH}$ activities of the first blood samples obtained (between 0.5 and 3.5 hours after onset of AMI) from the 26 patients monitored in this study are plotted on a relative scale against their respective reference values.

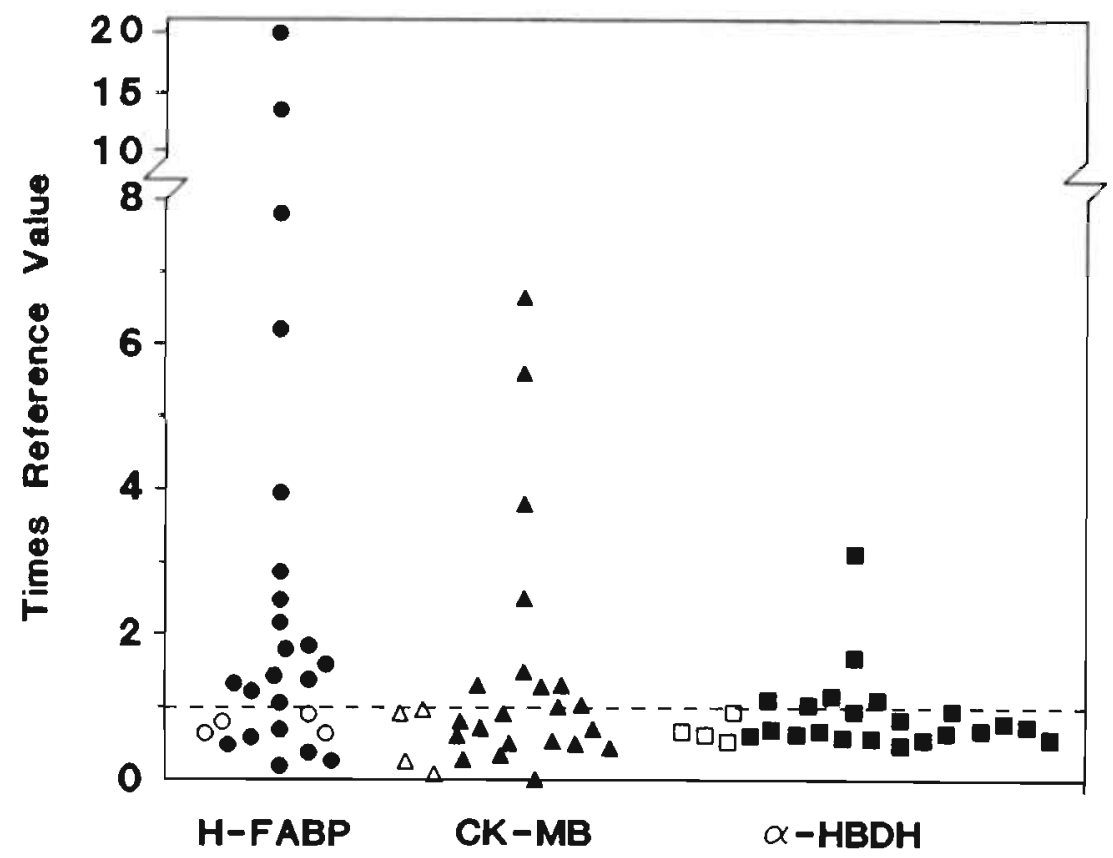

Figure 5.4. Plasma concentrations of H-FABP, CK-MB and $\alpha-\mathrm{HBDH}$ in first blood samples obtained from in total 26 patients, after admission to the hospital for cardiac complaints, in relative relation to their reference value in plasma. The dotted line indicates the relative reference value of H-FABP, CK$\mathrm{MB}$ and $\alpha-\mathrm{HBDH}$ in plasma. Solid symbols represent patients with established acute myocardial infarction (AMl, for establishment see Material and Methods), open symbols refer to patients eventually diagnosed having instable angina pectoris.

In 16 out of 22 patients with established AMI (for establishment of AMI see Material and Methods), i.e. 73\%, the plasma FABP concentration was already at or above the reference value in these early blood samples taken, while for CK-MB this was the case in only $9(=41 \%)$ and for $\alpha-\mathrm{HBDH}$ in $6(=27 \%)$ patients (Fig. 5.4., closed symbols). Furthermore, of the six patients who showed no significant rise in plasma FABP concentration in the first blood- sample taken, two showed a significantly elevated concentration of FABP (not of CK-MB or $\alpha-\mathrm{HBDH}$ ) in a 
second blood sample taken within 3.5 hours after AMI. The remaining four patients with established AMI showed significant rises in the plasma concentrations of FABP, CK-MB, and $\alpha-\mathrm{HBDH}$ in the second blood sample taken (between 3.5 and 8 hours after onset of the first symptoms). The four patients, from the total of 26, diagnosed as suffering from unstable angina pectoris (Fig.5.4. open symbols) showed no plasma concentrations of FABP, CK-MB or $\alpha-\mathrm{HBDH}$ above their respective reference value throughout the sampling period. Thus, for the early (within 3.5 hours) diagnosis of AMI the plasma concentration of FABP appears to have been a useful extra tool in 18 out of the 22 established AMI patients $(82 \%)$, that of CK-MB in 9 patients $(41 \%)$ and that of $\alpha-\mathrm{HBDH}$ in 6 patients $(27 \%)$. In the subgroup of 10 frequently sample patients four patients showed a plasma myoglobin concentration above the reference value in their firstly obtained blood sample (between 1.1 and 3.5 hours after AMI). Two patients from the subgroup showed a plasma myoglobin concentration above the reference value in a second plasma-sample taken within 3.5 hours after AMl. The remaining four patients from the subgroup showed plasma myoglobin concentrations above the reference value in the second blood sample taken (between 3.5 and 5 hours after onset of the first symptoms). Within the subgroup the data on plasma concentrations of myoglobin and FABP from the different patients match exactly. Because myoglobin was only measured in 10 of the 26 cardiac patients, data on myoglobin plasma concentrations were not included in Figure 5.4.

\subsection{Discussion.}

In this study we demonstrate the measurement of FABP in serial plasma samples of cardiac patients with initial diagnosis of acute myocardial infarction (AMI), using a highly sensitive enzyme linked immunosorbent assay (ELISA) of the sandwich type, newly developed for the measurement of human H-FABP in plasma samples. Sensitivity, accuracy and reproducibility of the assay were evident from a linear calibration curve (between 0 and 5 pg H-FABP) and an almost complete recovery of purified H-FABP added to plasma samples (see Chapter 3 , section 6). Comparison of the release of FABP into the circulation with that of CK$\mathrm{MB}$ and $\alpha-\mathrm{HBDH}$ revealed that the plasma concentration of the cytoplasmatic heart type FABP can be used especially for the early diagnosis of AMI in man. Judging from the (limited) data on plasma myoglobin concentrations in this study, FABP appears as useful as myoglobin as an early marker for AMI.

\section{Plasma reference oalues.}

Measurement of FABP content in human plasma of 72 healthy individuals revealed a normal plasma concentration of $9 \pm 5 \mu \mathrm{g} / 1$ (mean $\pm S D$ ), leading to a reference value of $19 \mu \mathrm{g} / 1$ (mean $+2 \times \mathrm{SD})$. Assuming a total plasma volume of 3 litres, this means there is a constant pool of some $60 \mathrm{\mu g}$ of FABP, at the most, present in the bloodstream. Because the FABPs from human heart and skeletal muscle are identical [16], and FABP from heart is not likely to be found in the bloodstream under normal conditions, the normal plasma concentration of FABP 
most probably stems for the greatest part from the continuous release of FABP from damaged skeletal myocytes. Although the mean FABP content of skeletal muscle is relatively low, i.e. $0.2 \mathrm{mg}$ per gram wet weight [16], the large total mass of striated muscle (about $40 \%$ of the body weight) makes that a human body contains about 6 grams of skeletal muscle FABP. Thus, the normal plasma concentration of FABP would represent less than $0.001 \%$ of this total amount. The normal plasma FABP concentration found is of similar magnitude as the value $(0$ $2.8 \mu \mathrm{g} / \mathrm{l})$ reported by Tanaka et al. [5], but 3 to 4 orders of magnitude lower than the plasma concentrations of $15-60 \mathrm{mg} / \mathrm{l}$ given by Knowlton et al. [4]. However, the latter value seems very unlikely since it would imply that under normal circumstances the plasma pool of FABP equals the amount of FABP present in 225900 grams of skeletal muscle tissue or $90-370$ grams of cardiac muscle tissue.

\section{FABP as indicator for AMI.}

The time curves of the plasma content of FABP and myoglobin and the plasma activities of CK-MB and $\alpha-\mathrm{HBDH}$ (cf. Fig. 5.1.) are the resultants of both the release into and the clearance from the circulation of these cytoplasmatic proteins. Comparison of the time curves of the plasma content of FABP and myoglobin and of the plasma activities of $\mathrm{CK}-\mathrm{MB}$ and $\alpha-\mathrm{HBDH}$ reveals that $\mathrm{FABP}$ and myoglobin are released into and cleared from the circulation more rapidly than is CK-MB and $\alpha-H B D H$. The rapid clearing will relate to the fact that small molecules like $\mathrm{H}$ FABP $\left(M_{r}=15 \mathrm{kDa}\right.$, molecular radius $\left.40 \AA\right)$ and myoglobin $\left(\mathrm{M}_{\mathrm{r}}=17.2 \mathrm{kDa}\right.$, molecular radius $20 \AA$ ) are easily cleared from the circulation by glomerular filtration [17-19] unlike larger molecules such as CK-MB $(80 \mathrm{kDa})$ or $\alpha-\mathrm{HBDH}(138 \mathrm{kDa})$ which stay in the circulation for a longer period of time. In case of normal renal functioning the greater part of the filtered low molecular weight (LMW) proteins will be reabsorbed by the renal tubules during their passage through the renal tubular system [18]. Only when the tubular reabsorptive mechanisms are saturated, or in certain cases of renal disease, the excess of LMW proteins will appear in the urine (LMW proteinuria) [17,18].

With the present immunoassay we were indeed able to qualitatively establish the presence of FABP in urine collected from some patients during their hospitalization (data not shown), thus confirming, at least partial, urinary excretion of FABP, similar to findings by Tanaka et al. [5]. In addition, the patient with the severe renal insufficiency showed elevated plasma FABP and myoglobin concentrations for a prolonged period of time.

The relatively short half-life time of FABP in plasma is helpful in maintaining a low normal c.q. low reference plasma value. In turn, as demonstrated in this study, the relatively low reference plasma value will permit the discrimination of elevated plasma concentrations earlier after AMI than the discrimination of elevated CK-MB or $\alpha-\mathrm{HBDH}$ concentrations from their respective reference values.

Furthermore, its low reference value and rapid clearing from plasma makes the plasma concentration of FABP not only useful for the early assessment of AMI, but most likely also for the demonstration of a recurrent infarction.

As stated in the introduction myoglobin has also been introduced a plasma marker for early indexation and quantification of acute myocardial infarction [6- 
13]. However, the discrimination between skeletal muscle and cardiac tissue damage will be more difficult with myoglobin than with $\mathrm{H}-\mathrm{FABP}$, since the skeletal muscle myoglobin content is approximately twice that of the heart $[20,21]$ while the FABP concentration in striated muscle is only $10-50 \%$ of that in human cardiac muscle [22]. Hence, estimation of extent of myocardial injury will be less influenced (4-20 times) by synchronously occurring skeletal muscle damage, in case of an FABP-measuring assay, compared to a myoglobin-measuring assay. Figure 5.2. may be illustrative for this complicating fact. Defibrillation (cardioversion) causes damage to the pectoral and intercostal skeletal muscles resulting in release of cytoplasmatic proteins into the circulation. Because of the high myoglobin/FABP ratio in skeletal muscle (32-70 see ref. [23]), we observed a greater influence of defibrillation on the plasma release curve of myoglobin than on the FABP plasma release curve (Fig. 5.2.).

\section{Concluding remarks.}

The plasma concentration of H-FABP was shown to be a useful parameter for the assessment or exclusion of acute myocardial infarction in man, in addition to the commonly used parameters, such as CK-MB and $\alpha-\mathrm{HBDH}$. Furthermore, as a plasma marker for damage of myocardial tissue H-FABP was found to have advantages over those of the enzymatic markers as it appears to be suitable especially for the early (within a few hours) detection of AMI. The reported sandwich ELISA, when adapted for more rapid clinical application, could become a valuable tool for the early assessment of AMI. In addition to its use for clinical diagnostic purposes, the use of plasma FABP as early marker of myocardial infarction will also be of interest for various types of experimental studies in which cardiac tissue damage may occur.

\subsection{SUMMARY.}

The release of cytoplasmatic heart-type fatty acid-binding protein (H-FABP) into the plasma of cardiac patients up to 38 hours after the onset of the first clinical symptoms of acute myocardial infarction (AMI) was studied. To this end, a sensitive direct and non-competitive Enzyme Linked Immunosorbent Assay of the antigen capture type (sandwich ELISA), newly developed for the measurement of small amounts of human H-FABP in plasma samples, was used. Plasma concentrations of FABP were compared with plasma concentrations of myoglobin and plasma activity values of the myocardial cytoplasmatic enzymes creatine kinase MB (CK-MB) and alpha-hydroxybutyrate dehydrogenase ( $\alpha$-HBDH). Upper normal concentrations of H-FABP $(19 \mu \mathrm{g} / \mathrm{l}), \mathrm{CK}-\mathrm{MB}(10 \mathrm{U} / \mathrm{l})$ and $\alpha$-HBDH $(160$ $\mathrm{U} / \mathrm{l}$ ) as determined in plasma from 72 blood donors served as reference values. In a subgroup of 10 patients also plasma concentrations of myoglobin were measured. For myoglobin the assay detection limit $(50 \mu \mathrm{g} / \mathrm{l})$ was also used as reference value. Both FABP and myoglobin mean concentrations were significantly elevated within 3 hours after AMI. Peak concentrations of FABP, myoglobin, CK-MB and $\alpha$-HBDH were reached $4.2 \pm 0.8$ hours, $4.2 \pm 0.8$ hours, $9.3 \pm 1.7$ hours and $24.3 \pm 10.2$ hours 
(mean $\pm 5 D, n=8$ ) after onset of AMI, respectively. Serial time curves of the plasma contents of FABP revealed that after myocardial infarction FABP is released in substantial amounts from human hearts. In 18 out of 22 patients with established AMI the plasma FABP concentrations was at or above the reference value in blood samples taken within 3.5 hours after the first onset of symptoms of AMl, while for $\mathrm{CK}-\mathrm{MB}$ this applied to 9 patients and for $\alpha-\mathrm{HBDH}$ only to 6 patients. These findings suggest that for an early indication of acute myocardial infarction in man cytoplasmatic heart FABP is more suitable than heart type creatine kinase $\mathrm{MB}$ and / or alpha-hydroxybutyrate dehydrogenase. The results of myoglobin measurement in a subgroup of 10 patients confirm the suggestion, as stated in other studies, that myog lobin may also be an early indicator for acute myocardial infarctions.

\subsection{REFERENCES.}

1. Glatz JFC, Van der Vusse GJ: Cellular fatty acid-binding proteins: Current concepts and future directions. Mol Cell Biochem 98: 237-251, 1990.

2. Glatz JFC, van Bilsen M, Paulussen RJA, Veerkamp JH, van der Vusse GJ, Reneman RS: Release of fatty acid-binding protein from isolated rat heart subjected to ischemia and reperfusion or to the calcium paradox. Biochim Biophys Acta 961: 148-152, 1988.

3. Knowlton AA, Apstein CS, Saouf R, Brecher P: Leakage of heart fatty acid binding protein with ischemia and reperfusion in the rat. I Mol Cell Cardiol 21: 577-583, 1989.

4. Knowlton AA, Burrier RE, Brecher P: Rabbit heart fatty acid-binding protein: Isolation, characterization, and application of a monoclonal antibody. Circ Res 65: 981-998, 1989.

5. Tanaka T, Hirota Y, Sohmiya K-l, Nishimura S, Kawamura K: Serum and urinary human heart fatty acid-binding protein in acute myocardial infarction. Clin Biochem 24: 195-201, 1991.

6. Stone MJ, Waterman MR, Harimoto D, Murray G, Wilson N, Platt MR, Blomqvist G, Willerson JT: Serum myoglobin level as diagnostic test in patients with acute myocardial infarction. $\mathrm{Br}$ Heart $J$ 39: $375-380,1977$.

7. Varki AP, Roby DS, Watts $\mathrm{H}$, Zatuchni J: Serum myoglobin in acute myocardial infarction: A clinical study and review of the literature. Am Heart ] 96: 680-688, 1978.

8. Drexel H, Dworzak E, Kirchmair W, Milz MM, Puschendorf B, Dienstl F: Myoglobinemia in the early phase of acute myocardial infarction. Am Heart / 105: 642-651, 1983.

9. McComb JM, McMaster EA, MacKenzie G, Adgey AAJ: Myoglobin and creatine kinase in acute myocardial infarction. Br Heart J 51: 189-194, 1984.

10. Isakov A, Shapira I, Burke M, Almog C: Serum myoglobin levels in patients with ischemic myocardial insult. Arch Intern Med 148: 1762-1765, 1988.

11. Ellis AK, Saran BR: Kinetics of myoglobin release and prediction of myocardial depletion after coronary artery reperfusion. Circulation 80: 676-683, 1989.

12. Ohman EM, Casey C, Bengtson JR, Pryor D, Tormey W, Horgan JH: Early detection of acute myocardial infarction: additional diagnostic information from serum concentrations of myoglobin in patients without ST elevation. Br Heart / 63: 335-338, 1990.

13. Driessen-Kletter MF, Amelink GI, Bär PR, van Gijn J: Myoglobin is a sensitive marker of increased muscle membrane vulnerability. I Neurol 237: 234-238, 1990.

14. Rosalki SB, Wilkinson JH: Reduction of alpha-ketobutyrate by human serum. Nature 188: 1110$1111,1960$.

15. Ingelfinger JA, Mosteller F, Thibodeau LA, Ware, JH. In: Biostatistics in clinical medicine. New York, MacMillan Publishing Co., Inc., pp. 85-113, 1983.

16. Peeters RA, Veerkamp JH, Kanda T, Ono T, Van Kessel AD: Cloning of the cDNA encoding human skeletal muscle fatty acid-binding protein, its peptide sequence and chromosomal localization. Biochem / 276: 203-207, 1991. 
17. Waldmann TA, Strauber $W$, Mogielnicki RP: The renal handling of low molecular weight proteins. II.Disorders of serum protein catabolism in patients with proteinuria, the nephrotic syndrome, or uremia. / Clin lnvest 51: 2162-2174, 1972.

18. Hall CL, Hardwicke J: Low molecular weight proteinuria. Ann Rev Med 30. 199-211, 1979.

19. Klocke FJ. Copley DP, Krawczyk JA, Reichlin M: Rapid renal clearance of immunoreactive canine plasma myoglobin. Circulation 65: 1522-1528, 1982.

20. Sylvén C. Jansson E, Boör K: Myoglobin content in human skeletal muscle and myocardium: relation to fibre size and oxidative capacity. Cardiovasc Res 18: 443-446, 1984.

21. Lin L, Sylvén C, Sotonyi P, Somogyi E. Kaijser L, Jansson E: Myoglobin content and citrate synthase activity in different parts of the normal human heart. / Appl Physiol 69: 899-901, 1990.

22. Paulussen RJA Van Moerkerk HTB, Veerkamp JH: Immunochemical quantitation of fatty acidbinding proteins. Tissue distribution of liver and heart FABP types in human and porcine tissues. Int I Biochem 22: 393-398, 1990.

23. Van Nieuwenhoven FA, Kleine AH, Keizer HA, Van Dieijen MP, Van Der Vusse GJ, Glatz JFC: Comparison of myoglobin and fatty acid-binding protein as plasma markers for muscle damage in man. Eur / Physiol (Pflügers Arch) 421: R 40, 1992. 
CHAPTER 6

\section{QUANTITATION OF MYOCARDIAL INFARCTION IN MAN WITH THE USE OF HEART-TYPE FABP PLASMA CONCENTRATIONS*}

6.1. Introduction. $p^{72}$

6.2. Patients, Material and methods p 72

6.3. Results p 76

6.4. Discussion p 79

6.5. Summary p 86

6.6. References $\mathrm{p} 87$

Adapted from Glatz JFC, Kleine AH, van Nieuwenhoven FA, Hermens WT, van Dieijen-Visser MP, van der Vusse GJ: Fatty acid-binding protein as plasma marker for the estimation of myocardial infarct size in man (submitted). 


\subsection{INTRODUCTION.}

Assessment or exclusion of acute myocardial infarction (AMI) in man is usually performed by the measurement in plasma of the activities of cardiospecific enzymes, such as creatine kinase isozyme MB (CK-MB) and $\alpha$-hydroxybutyrate dehydrogenase $(\alpha-\mathrm{HBDH})[1,2]$, or of the concentrations of cardiac proteins such as myoglobin [3-7] and troponin $T$ [8,9]. Since myoglobin appears in substantial quantities in plasma already 2-3 hours after the onset of AMI while this takes at least 4 hours for the other proteins (see Chapter 5), it has been suggested that myoglobin is a biochemical marker suitable especially for the early assessment of AMI [3-7], and for the detection of reperfusion after thrombolytic therapy $[10,11]$. In addition, it has been demonstrated that both myoglobin [12] and enzymes [13] released from the heart after AMI are completely recovered in plasma. Hence, the cumulative release of each of these markers can be used to estimate infarct size in gram-equivalents of healthy myocardium per litre of plasma.

Recently, heart-type fatty acid-binding protein (H-FABP) has also been suggested as early plasma marker for AMI [14-16]. This relatively small (15 kDa) cytoplasmatic protein is abundantly present in cardiomyocytes and is assumed to function in myocardial lipid homeostasis [17,18]. Evidence has been presented [ref.19 and Chapter 5] that after AMI H-FABP is released in substantial amounts from human hearts and that, similar to myoglobin, plasma H-FABP levels are significantly elevated above threshold level within 3 hours and return to normal levels within 24 hours after AMI. It is not yet known, however, whether H-FABP is completely released from damaged tissue and whether this protein can also serve as biochemical marker for the estimation of myocardial infarct size.

In the present study the release of H-FABP, myoglobin, CK, CK-MB and $\alpha-$ $\mathrm{HBDH}$ into plasma after AMI was compared, and infarct size estimated from the plasma curve areas of these parameters. The data indicate that H-FABP released from the heart after AMI is recovered quantitatively in plasma and is a suitable marker for the estimation of myocardial infarct size.

\subsection{Patients, Materials and Methods.}

\section{Patients and blood sampling.}

Fifty patients (6 females, 44 males; age 29-71) with chest pain and ST-segment elevation typical of AMI were studied. Patients were eligible for this study if admitted to the coronary care unit of the hospital within 6 hours after the onset of infarct-related symptoms. They participated in a pilot study on treatment with a new inhibitor of platelet function by selective blockade of thromboxane $\mathrm{A}_{2}$ synthetase (Ridogrel ${ }^{\star}$, Janssen Pharmaceutics, Beerse, Belgium), and also received thrombolytic therapy with tissue-type plasminogen activator (Alteplase ${ }^{\star}$, Boehringer Ingelheim, Germany) and heparin. Coronary angiography, performed at 90 minutes after start of thrombolytic treatment, revealed successful reperfusion in 40 patients and, upon subsequent percutaneous transluminal coronary angioplasty (PTCA), also in the remaining cases. Ischemia was located anteriorly in 13 
patients and inferio-posteriorly in 37 patients. Cardioversion was performed in none of the patients. Plasma samples remained incomplete for one patient who died; the results of the remaining 49 patients are shown. Further details on patient selection and clinica] treatment are described elsewhere [20].

Blood samples were taken upon admission to the hospital $(2.9 \pm 1.3$ hours range 1.1-6.0 hours - after onset of first symptoms; mean \pm SD for $n=49$ ) and 3, 6, $9,12,24,36,48,72$ and (for 35 patients only) 96 hours thereafter, resulting in 9-10 samples per patient. Samples were collected in glass tubes containing dry heparin. After routine centrifugation plasma was stored in several aliquots at $-20^{\circ} \mathrm{C}$ until analysis.

\section{Tissue sampling.}

Myocardial contents of H-FABP and myoglobin were measured in intact parts of left ventricular tissue obtained from the department of Pathology (head: Dr. J. Koudstaal) of the De Wever Hospital in Heerlen after autopsy on patients who died from non-cardiac causes. Autopsy was performed within 12 hours after death. H-FABP and myoglobin contents, each assayed with the same method as used for plasma, were $0.56 \pm 0.07$ and $2.70 \pm 0.61 \mathrm{mg} / \mathrm{g} \mathrm{ww}$, respectively (means $\pm \mathrm{SD}$ for 17 subjects, see Table 6.1.). The contents of each of the proteins showed no significant regional or transmural differences in the left ventricle (Van DieijenVisser, manuscript in preparation). The myoglobin to H-FABP ratio calculated from these data is $4.9 \pm 1.2$ (mean $\pm S D, n=17$ ). Myocardial enzyme contents, as measured previously under the same assay conditions as applied for plasma in the present study, were for CK $865 \mathrm{U} / \mathrm{g}, 123 \mathrm{U} / \mathrm{g}$ for $\alpha-\mathrm{HBDH}$ [21] and $132 \mathrm{U} / \mathrm{g}$ for CK-MB [22].

\section{Analytical techniques.}

$\mathrm{H}-\mathrm{FABP}$ was determined in plasma and tissue samples using a sensitive non-competitive enzyme-linked immunosorbent assay of the antigen capture type (sandwich ELISA), as previously described (Chapter 3, section 6).

Myoglobin concentrations of plasma were assayed with the method of Delanghe et al. [23], using the turbidimetric immunoassay described in Chapter 2, section 10.

Activities of $\mathrm{CK}, \mathrm{CK}-\mathrm{MB}$ and $\alpha-\mathrm{HBDH}$ in plasma samples were measured spectrophotometrically at $25^{\circ} \mathrm{C}$ using a centrifugal analyzer (Cobas Bio System, Hoffmann La Roche, Basel, Switzerland) and commercially available test kits (see Chapter 2, section 11).

\section{Plasma threshold levels.}

For estimation of the reference values in plasma of H- FABP, CK-MB and $\alpha$ $\mathrm{HBDH}$ these proteins were assayed in non-haemolytic blood samples obtained from 72 healthy blood donors as described in Chapter 3, section 6 (H-FABP) and Chapter 2, section 11 (CK-MB and $\alpha-\mathrm{HBDH}$ ). Plasma activities of CK-MB and $\alpha-$ $\mathrm{HBDH}$ were $4 \pm 3 \mathrm{U} / 1$ and $90 \pm 35 \mathrm{U} / 1$ (mean $\pm \mathrm{SD}$ ), respectively, and the plasma 
$\mathrm{H}$-FABP concentration was $9 \pm 5 \mu \mathrm{g} / \mathrm{l}$ (mean $\pm \mathrm{SD}$ ). The threshold value was taken as the mean plasma level plus twice the standard deviation, leading to threshold levels of $10 \mathrm{U} / 1$ for CK-MB, $160 \mathrm{U} / 1$ for $\alpha-\mathrm{HBDH}$ and $19 \mu \mathrm{g} / 1$ for H-FABP. For myoglobin a plasma threshold value of $50 \mu \mathrm{g} / \mathrm{l}$ was taken, which is the detection limit of the turbidimetric assay. Using a more sensitive method, Stone et al. [5] found the plasma myoglobin content of healthy volunteers to amount to $31 \pm 15$ $\mu \mathrm{g} / \mathrm{l}$ (mean $\pm \mathrm{SD}, \mathrm{n=135}$ ). According to the above definition this would also produce a threshold level for myoglobin on the order of $50 \mu \mathrm{g} / \mathrm{l}$. For CK a plasma activity of $45 \pm 15 \mathrm{U} / \mathrm{l}$ was used, leading to a threshold level of $90 \mathrm{U} / 1$ (Hermens, unpublished data).

\section{Calculation of cumulative protein release and estimation of myocardial infarct size.}

Cumulative release of cardiac proteins from the onset of AMI ( $t=0)$ up to time $t, Q(t)$, was calculated with the following expression for a two-compartment model [24]:

$$
Q(t)=C(t)+\operatorname{TER} \exp \int_{0}^{t}[\operatorname{RRR}(\tau-\tau)] c(\tau) d \tau+\operatorname{PCR} \int_{0}^{t} c(\tau) d \tau
$$

The three terms are the actual protein concentration (or enzyme activity) in plasma, the extravascular concentration, and the amount of protein eliminated from plasma, respectively, each expressed per litre of plasma. The parameters TER, ERR and FCR are the fractional rate constants for transcapillary escape, extravascular return, and catabolism (elimination) of protein, respectively.

For CK-MB the parameter values used were: $T E R=0.014 \mathrm{~h}^{-1}, \mathrm{ERR}=0.018 \mathrm{~h}^{-1}$ and FCR $=0.34 \mathrm{~h}^{-1}$. For CK and $\alpha-\mathrm{HBDH}$ the values for TER and ERR were equal to those of CK-MB. The FCR of CK and $\alpha-\mathrm{HBDH}$ amounted to $0.2 \mathrm{~h}^{-1}$ and $0.015 \mathrm{~h}^{-1}$, respectively $[24,25]$. For H-FABP and myoglobin, calculation of the cumulative release is hampered by the fact that both proteins the fractional rate constants are not known. However, as outlined in more detail elsewhere [12], in man myoglobin is cleared from the circulation predominantly by rapid renal clearance, so that its cumulative release into plasma after AMI can be calculated with a onecompartment (i.e. plasma volume) model. This implies that the second term in the above formula can be omitted. Since the mean half-life time of myoglobin in AMI patients is 16 minutes [26] the FCR was estimated to be $2.6 \mathrm{~h}^{-1}$ (cf. ref. 12).

The ratio of the plasma concentrations of myoglobin and $\mathrm{H}-\mathrm{FABP}$ being constant during the entire period ( 24 hours) of elevated plasma levels (see Fig. 6.3) indicates that most likely H-FABP will also be eliminated from plasma mainly by rapid renal clearance. Therefore, cumulative release of $\mathrm{H}$-FABP was calculated with the same formula as used for myoglobin (see Discussion). The validity of the use of such a one-compartment model has been demonstrated in the dog for both circulating myoglobin [27] and FABP [28]. 
Before calculations were made, for each patient measured plasma protein levels and enzyme activities were corrected by subtraction of the normal steady-state values. For this we used either the level or activity measured in the first plasma sample taken from the patient (if obtained within 4 hours after the onset of symptoms and if not above the threshold value) or fixed mean values of $90 \mathrm{U} / 1$ for $\mathrm{CK}, 10 \mathrm{U} / \mathrm{l}$ for CK-MB, $160 \mathrm{U} / 1$ for $\alpha-\mathrm{HBDH}, 19 \mu \mathrm{g} / 1$ for H-FABP and $50 \mu \mathrm{g} / 1$ for myoglobin. For each cardiac protein examined the cumulative release per litre of plasma was divided by the myocardial content of the specific protein per gram of wet weight tissue, so that myocardial injury could be expressed in gram-equivalents of healthy heart muscle per litre of plasma.

Table 6.1. H-FABP AND MYOCLOBIN CONTENT OF HUMAN HEAKTS

\begin{tabular}{|c|c|c|c|c|c|c|c|}
\hline patient & $\begin{array}{c}\text { age } \\
\text { (years) }\end{array}$ & sex & cause of death & $\begin{array}{l}\text { heart } \\
\text { weight } \\
(g)\end{array}$ & $\begin{array}{l}\text { autopsy } \\
\text { delay }(h)\end{array}$ & $\begin{array}{l}\text { H-FABP } \\
\text { content } \\
\text { (mg/gWW) }\end{array}$ & $\begin{array}{l}\text { myoglobin } \\
\text { conten! } \\
(\mathrm{mg} / \mathrm{gWW} \text { " }\end{array}$ \\
\hline 1 & 80 & $f$ & hypovolemia & 260 & 26 & 0.65 & 2.83 \\
\hline 2 & 74 & m & pneumonia & 380 & 4 & 0.52 & 2.18 \\
\hline 3 & 55 & m & cva"* & 850 & 24 & 0.54 & 2.40 \\
\hline 4 & 76 & f & carcinoma & 325 & 5 & 0.46 & 3.68 \\
\hline 5 & 74 & m & carcinoma & 370 & 7 & 0.53 & 2.33 \\
\hline 6 & 70 & $\mathrm{~m}$ & fibrosis of the lungs & 350 & $<24$ & 0.56 & 2.23 \\
\hline 7 & 86 & m & heart decompensation & 740 & 8 & 0.51 & 2.51 \\
\hline 8 & 74 & $f$ & lung emphysema & 280 & 16 & 0.58 & 3.57 \\
\hline 9 & 20 & $f$ & $\mathrm{cva}^{* *}$ & 330 & 21 & 0.55 & 2.23 \\
\hline 10 & 75 & $\mathrm{~m}$ & sepsis & 430 & 22 & 0.49 & 2.25 \\
\hline 11 & 36 & f & cva** & 310 & 15 & 0.73 & 3.99 \\
\hline 12 & 83 & f & lung emphysema & 215 & 12 & 0.63 & 3.00 \\
\hline 13 & $T 7$ & m & pneumonia & 370 & 5 & 0.70 & 3.21 \\
\hline 14 & 90 & $f$ & carcinoma & 380 & 3 & 0.53 & 2.02 \\
\hline 15 & 54 & $f$ & carcinoma & 300 & $<24$ & 0.60 & 1.96 \\
\hline 16 & 57 & $f$ & carcinoma & 500 & 8 & 0.44 & 2.97 \\
\hline \multirow[t]{3}{*}{17} & 74 & $\mathrm{~m}$ & lung emphysema & 300 & 7 & 0.53 & 2.61 \\
\hline & & & & & mean & 0.56 & 2.70 \\
\hline & & & & & $\mathrm{SD}$ & 0.07 & 0.61 \\
\hline
\end{tabular}

"(mg/gWW): mg protein per gram wet weight of heart tissue; "cva: cerebrovascular accident.

\section{Validation of sampling protocol.}

The validity of the use of the present sampling protocol, in which less frequently blood samples were taken than in the study described in Chapter 5 , for calculation of the cumulative release of H-FABP and myoglobin was studied in a separate set of 10 patients (1 female, 9 males; age 45-75) with clinically confirmed AMI, from whom hourly plasma samples were obtained up to 12 hours after admission to the hospital. The cumulative protein release calculated on the basis of samples obtained at $0,3,6,9$, and 12 hour after admission to hospital correlated significantly with the release calculated on the basis of all 13 samples (Fig. 6.1; 
$r=0.97$ for $\mathrm{H}-\mathrm{FABP}$ and $\mathrm{r}=0.99$ for myoglobin; $\mathrm{P}<0.05$ ), indicating that also for these proteins the less frequent sampling protocol will yield good estimates of cumulative protein release.

\section{Statistics.}

Release curves of proteins into plasma are presented as means \pm SEM for sake of clarity. Statistical analysis of differences (between groups) was performed with the Student $t$-test. The level of significance was set at $P<0.05$.

\subsection{RESULTS.}

Mean plasma concentrations or activities of the four proteins examined as a function of time for 49 patients (Fig. 6.2) reveal a large difference between the plasma kinetics of H-FABP and myoglobin on the one side and those of CK-MB and $\alpha-\mathrm{HBDH}$ on the other side. Results for CK and CK-MB were similar so that the former are not shown. The plasma peak levels of H-FABP and myoglobin were reached already $5.7 \pm 1.4$ and $5.8 \pm 1.4$ hours after AMI, respectively, but that of CK-MB was reached $11.7 \pm 4.4$ hours after AMI and that of $\alpha-\mathrm{HBDH} 28.2 \pm 13.5$ hours after $A M I$ (mean $\pm S D, n=49$ ). Within 24 hours the plasma concentrations of both H-FABP and myoglobin had returned to normal levels, while for CK-MB this took about 50-70 hours and for HBDH more than 70 hours (Fig. 6.2). The mean ratio of the plasma concentrations of myoglobin and H-FABP was found to be 4.7 \pm 0.8 (mean $\pm S D, n=49$ ) in the first blood sample taken. This value remained fairly constant (range 3.6 - 5.5) during a sampling period of 24 hours after onset of AMI, in which both H-FABP and myoglobin show plasma values above their respective thresholds (Fig. 6.3). After this period the myoglobin/H-FABP ratio increases because the lowest measurable myoglobin plasma concentration is $50 \mu \mathrm{g} / \mathrm{l}$ (detection limit), while the H-FABP assay allows for measuring concentrations below the threshold value. The value for the plasma myoglobin/H-FABP ratio (4.7) corresponded to the myoglobin/H-FABP ratio of healthy myocardium of $4.9 \pm 1.2$ (mean \pm SD for 17 samples; see Patients, Material and Methods).

One patient developed a recurrent myocardial infarction soon ( $<10$ hours) after the initial AMI. The appearance of this recurrent infarction is reflected clearly in the plasma curves for H-FABP and myoglobin but is less apparent from the $\mathrm{CK}-\mathrm{MB}$ and $\alpha-\mathrm{HBDH}$ plasma curves (Fig. 6.4).

The cumulative release patterns of the four proteins, expressed in gramequivalents of tissue per litre of plasma, also show a difference between H-FABP and myoglobin on the one side and CK-MB and $\alpha-\mathrm{HBDH}$ on the other side (Fig. 6.5). The release of H-FABP and of myoglobin appears to occur and be completed much earlier than those of CK-MB and $\alpha-\mathrm{HBDH}$. For instance, at 12 hours after AMI about $75 \%$ of the total amounts of eventually released H-FABP and myoglobin had appeared in plasma, but only $42 \%$ of that of CK-MB and $\alpha-\mathrm{HBDH}$ (Fig. 6.5). Total release of H-FABP and of myoglobin were virtually completed 24-36 hours after AMI, but that of CK-MB took about 50 hours and that of HBDH more than 70 hours. Despite this kinetic difference, for each of the four proteins 
the released total quantities yield comparable estimates of the mean extent of injury when evaluated at $72 \mathrm{hrs}$ after the onset of AMI (Fig. 6.5). The latter is also apparent from significant correlations between pairs of the release of each of the four proteins when expressed as calculated infarct size (Fig. 6.6). Among these the total release of H-FABP correlated better with that of myoglobin $(r=0.89, \mathrm{P}<0.05)$ than with that of CK $(r=0.75, \mathrm{P}<0.05), \mathrm{CK}-\mathrm{MB}(\mathrm{r}=0.56, \mathrm{P}<0.05)$ or $\alpha-\mathrm{HBDH}(\mathrm{r}$ $=0.49, \mathrm{P}<0.05$ ).
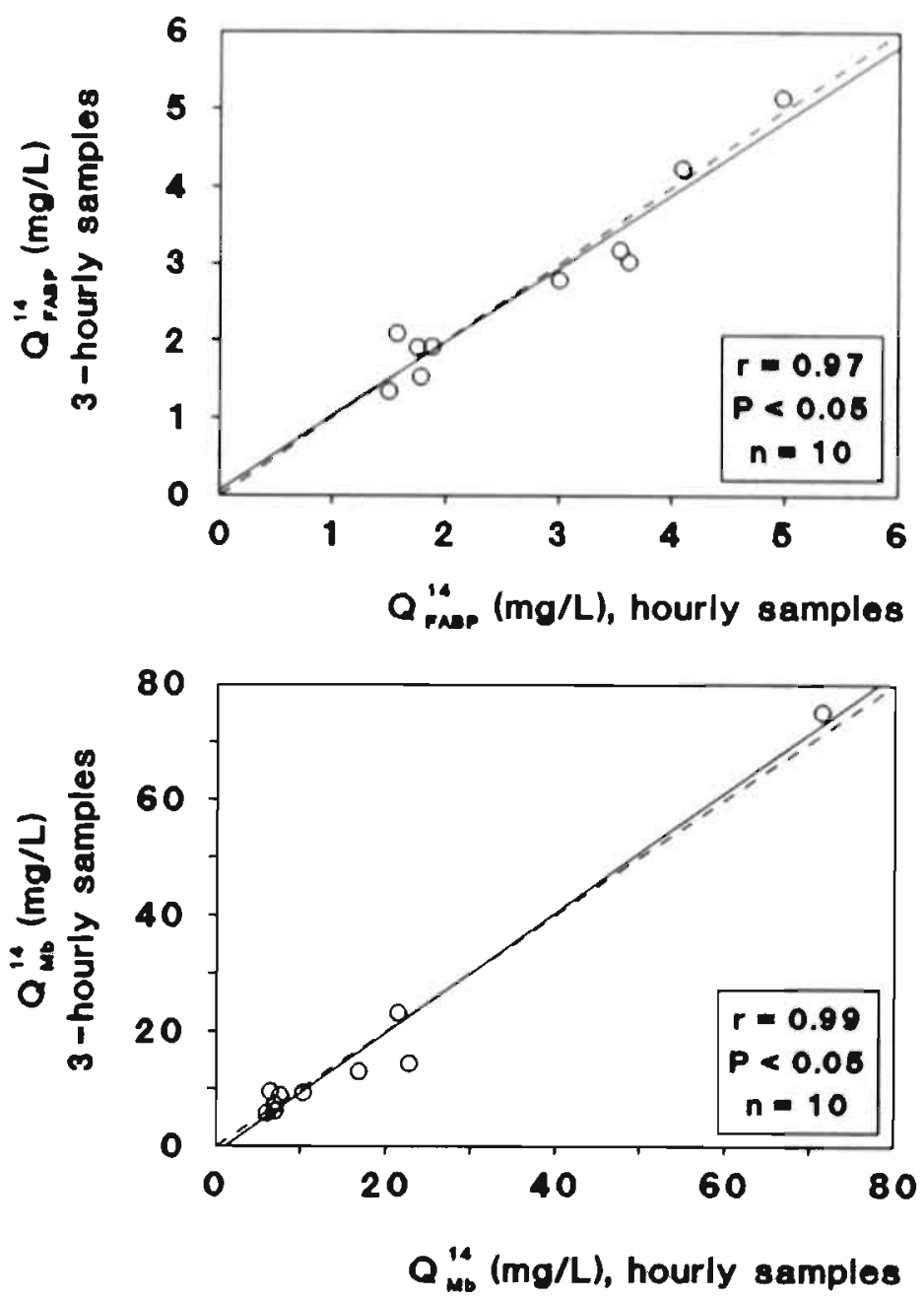

Figure 6.1. Relationship between the cumulative release over 14 hours $\left(Q^{14}\right)$ of H-FABP (upper panel) and myoglobin (lower panel) into plasma as calculated from plasma concentrations from 5 or 13 blood samples. The lines of identity are given (dotted lines). The calculated regression lines (solid lines) are: $Y=0.07 X+0.96$ (upper plot) and $Y=-1.15 X+1.04$ (lower plot). 

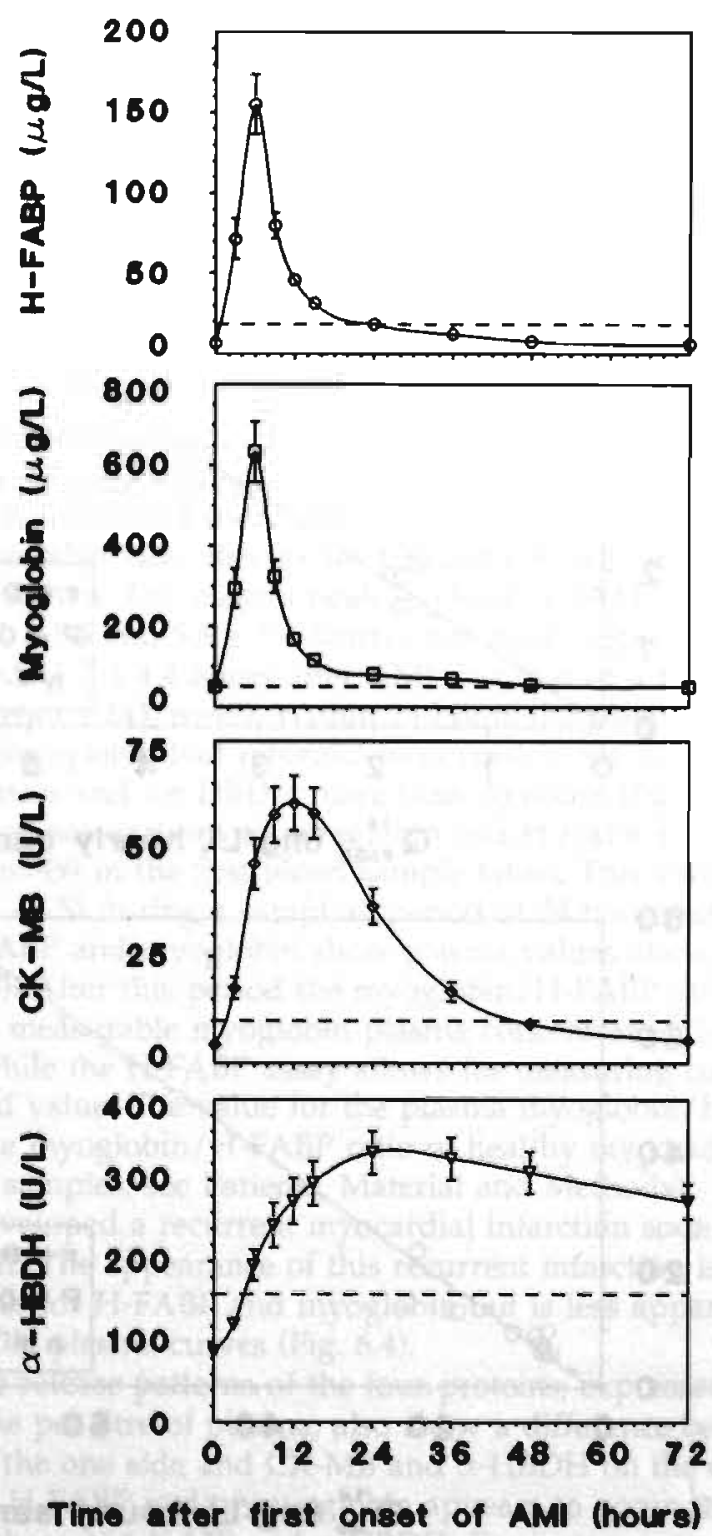

Figure 6.2. Plasma concentrations of H-FABP and myoglobin (left-hand panels), and plasma activities of CK-MB and $\alpha$-HBDH (right-hand panels), as function of time after AMI in 49 patients. Data are means \pm SEM. Dotted lines indicate threshold levels of H-FABP, CK-MB and $\alpha-H B D H$ in normal human plasma, and assay detection limit for myoglobin (see text for details). 


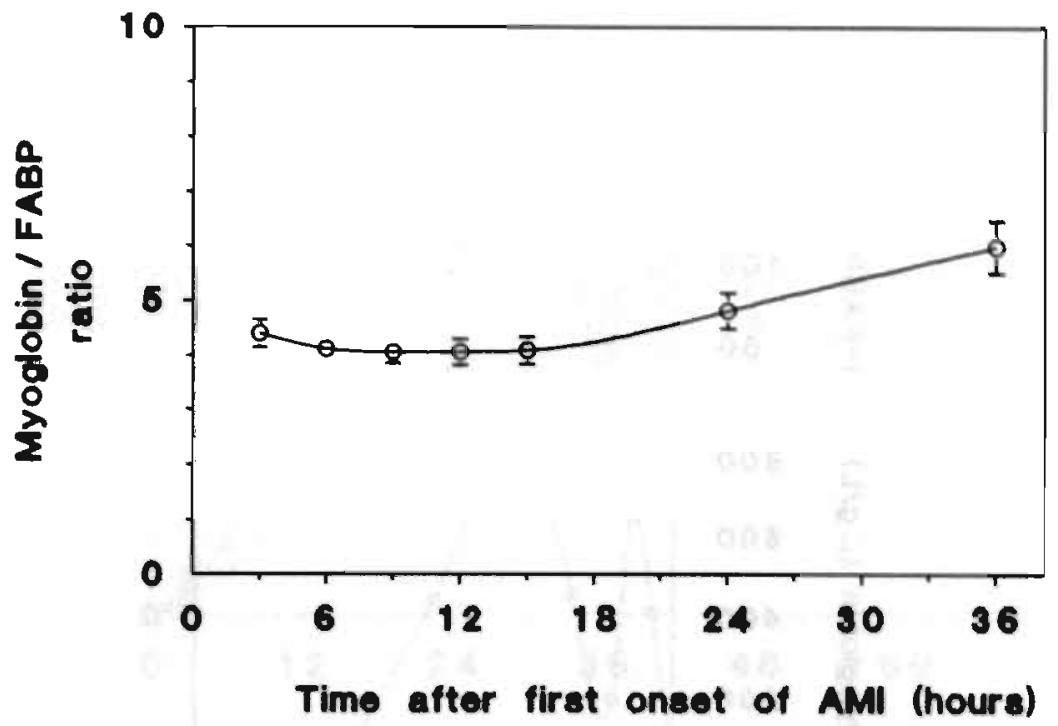

Figure 6.3. Plasma myoglobin/H-FABP ratio as function of time after AMI in 49 patients. Datu are means \pm SEM.

\subsection{Discussion.}

The rationale for using fatty acid-binding protein (FABP) as plasma marker for myocardial injury is based on the presence of this soluble protein in the myocardium in a relatively large quantity and its virtual confinement to the cytoplasmatic space. FABP has also been detected in the matrix of bovine heart mitochondria [29,30], but total mitochondrial FABP represents less than $1 \%$ of the cellular content [29]. In previous studies [refs. 16,19 and Chapter 5] it was established that in man plasma FABP levels significantly increase upon ischaemic myocardial injury and, hence, that FABP is a useful qualitative parameter for the assessment or exclusion of acute myocardial infarction. In the present study it is shown that the release of H-FABP from damaged tissue is essentially complete within 36 hours from the onset of AMI and that the cumulative release of H-FABP into plasma can be used to estimate myocardial infarct size.

\section{Plasma kinetics of H-FABP.}

For the calculation of cumulative release we assumed the plasma kinetics of $\mathrm{H}$ FABP to be similar to that of myoglobin. This implies that the elimination of these proteins from plasma can be described with a one-compartment (i.e. plasma volume) model, because their plasma kinetics are dominated entirely by the high rate of protein elimination from plasma so that extravasation can be neglected [12]. 

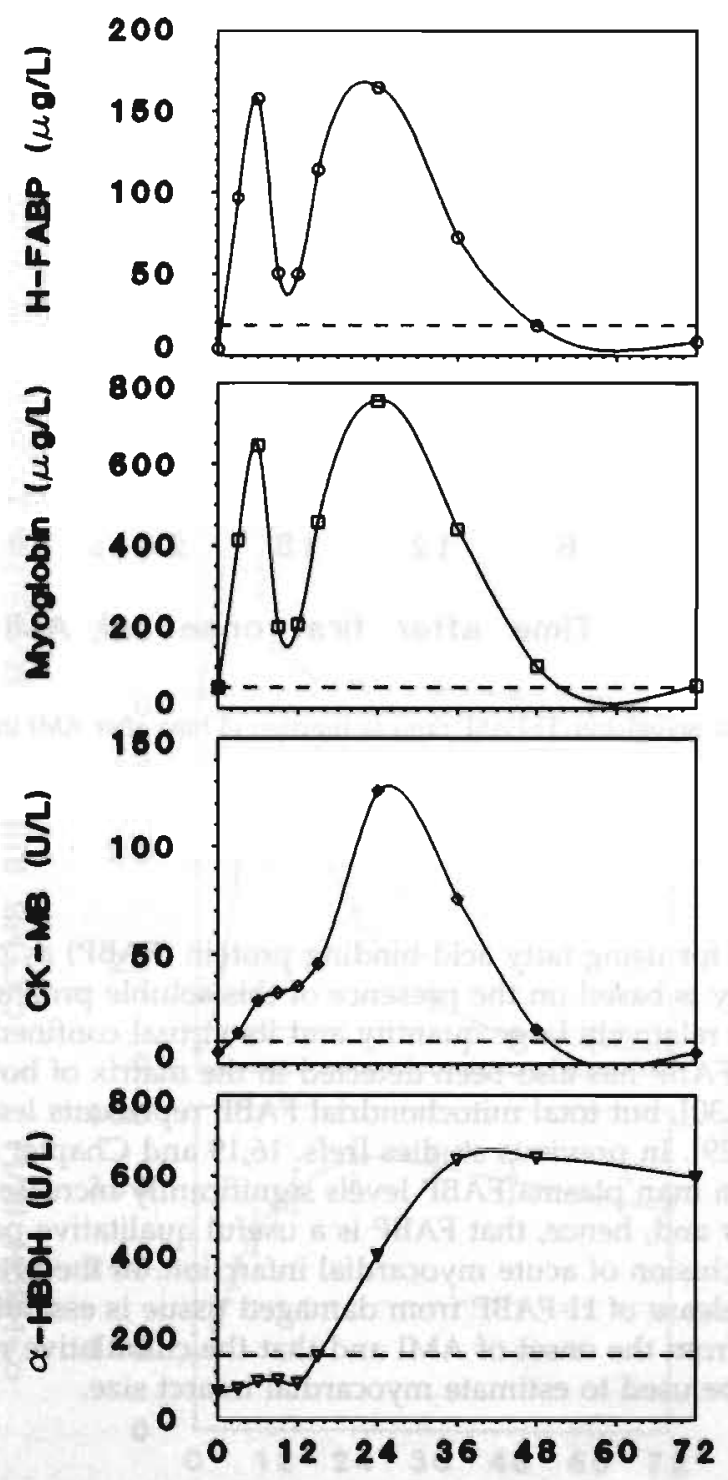

Time after first onset of AMI (houra)

Figure 6.4. Plasma concentrations of H-FABP and myoglobin, and plasma activities of CK-MB and $\alpha-H B D H$ as function of time after initial AMI in a patient who developed a recurrent AMI. Dotted lines indicate threshold levels of H-FABP, CK-MB and $\alpha-\mathrm{HBDH}$ in normal human plasma, and assay detection limit for myoglobin (see text for details). 


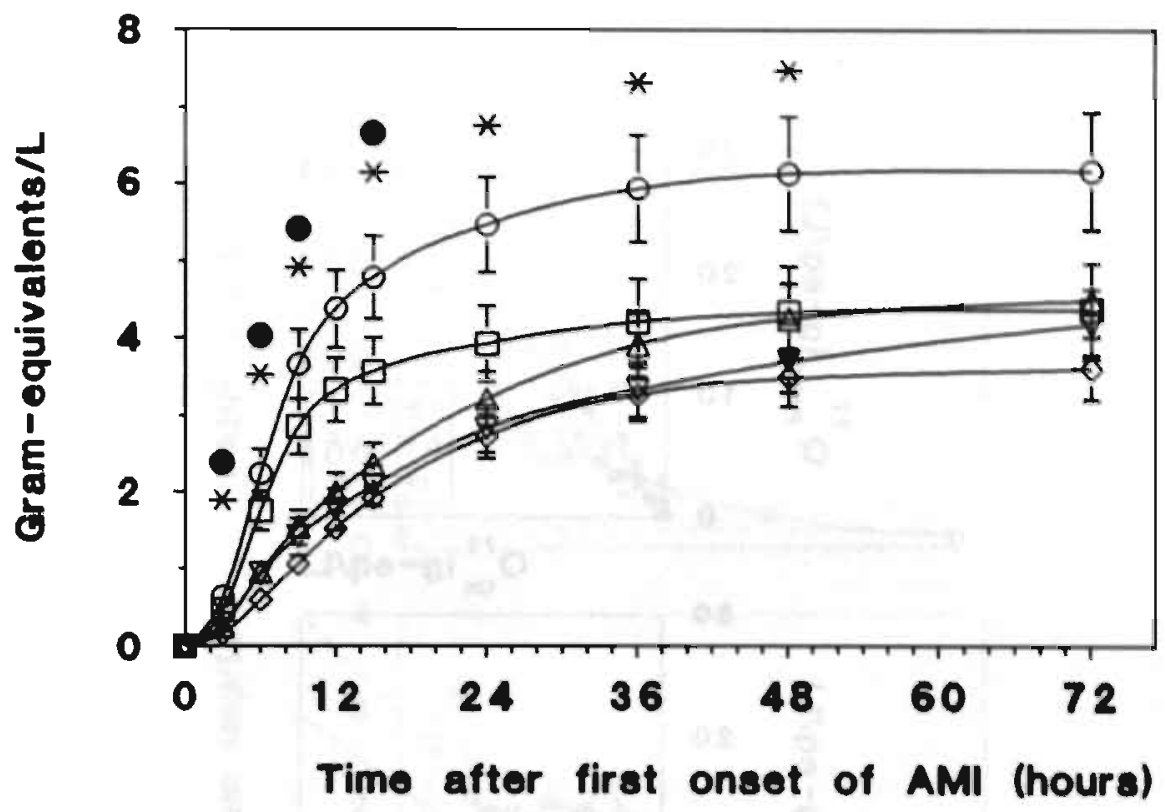

Figure 6.5. Cumulative release of H-FABP $(0)$, myoglobin $(\square), C K(\Delta), C K-M B(0)$ and $\alpha-H B D H$ $(\nabla)$ in plasma after AMI in 49 patients. Data are expressed in gram-equivalents of healthy myocardium per litre of plasma and represent means \pm SEM. At each point the cumulative release of H-FABP and myoglobin were tested for significant difference $(P<0.05)$ from the cumulative release of $C K$. *, cumulative release of H-FABP significantly higher than cumulative rel ase of $r K_{;} \phi$, cumulative release of myoglobin significantly higher than cumulative release of $\mathrm{CK}$.

Even if significant extravasation of H-FABP would occur, this would only affect the shape of the release curve and, provided that a full curve is recorded, not the cumulative release over time, which is the parameter of interest.

For a one-compartment model the cumulative protein release equals the integrated plasma curve, multiplied by FCR. The latter was assumed to be similar to that of myoglobin, $2.6 \mathrm{~h}^{-1}$ [12] (see discussion below).

The validity of this approach appeared from essentially the same plasma curves found for H-FABP and myoglobin, and from the constant ratio of the plasma concentrations of myoglobin to that of H-FABP (Fig. 6.3). From this we conclude that H-FABP is eliminated from plasma predominantly by rapid renal clearance, like myoglobin. The reported detection of H-FABP in urine samples collected as early as 2 hours after onset of chest pain [19] is in accordance with this conclusion. Furthermore, earlier we found that in a patient suffering from severe renal insufficiency the occurrence of AMI resulted in elevated plasma H-FABP levels beyond 25 hours after onset of symptoms (see Chapter 5). 

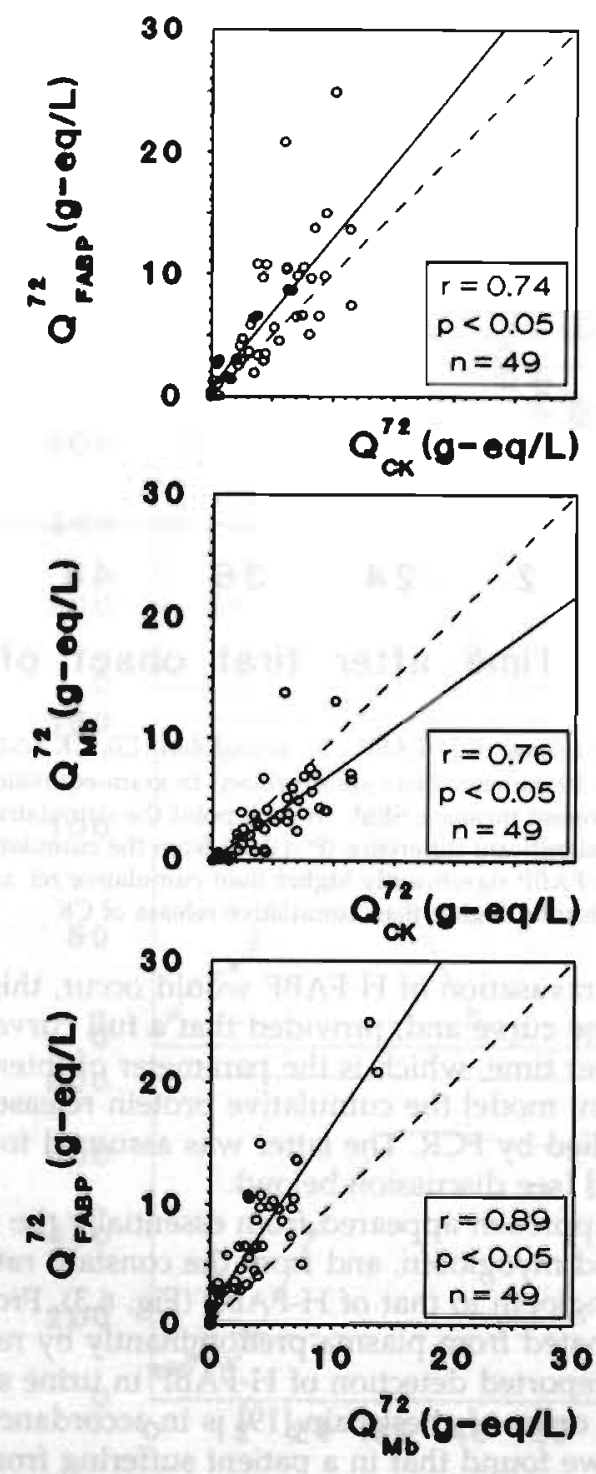

Figure 6.6. Scattergrams of infarct size estimated from the release of H-FABP, myoglobin and CK into plasma after AMI in 49 patients. Infarct size is expressed in gram-equivalents of healthy myocardium per litre of plasma over a sampling period of 72 hours $\left(Q^{2}\right)$. The calculated regression lines (solid line) are: $Y=1.7 X+0.45$ (upper plot), $Y=1.9 X+0.79$ (middle plot), and $Y=0.004 X+$ 0.52 (lower plot). The line of identity is given in each plot (dotted lines). 

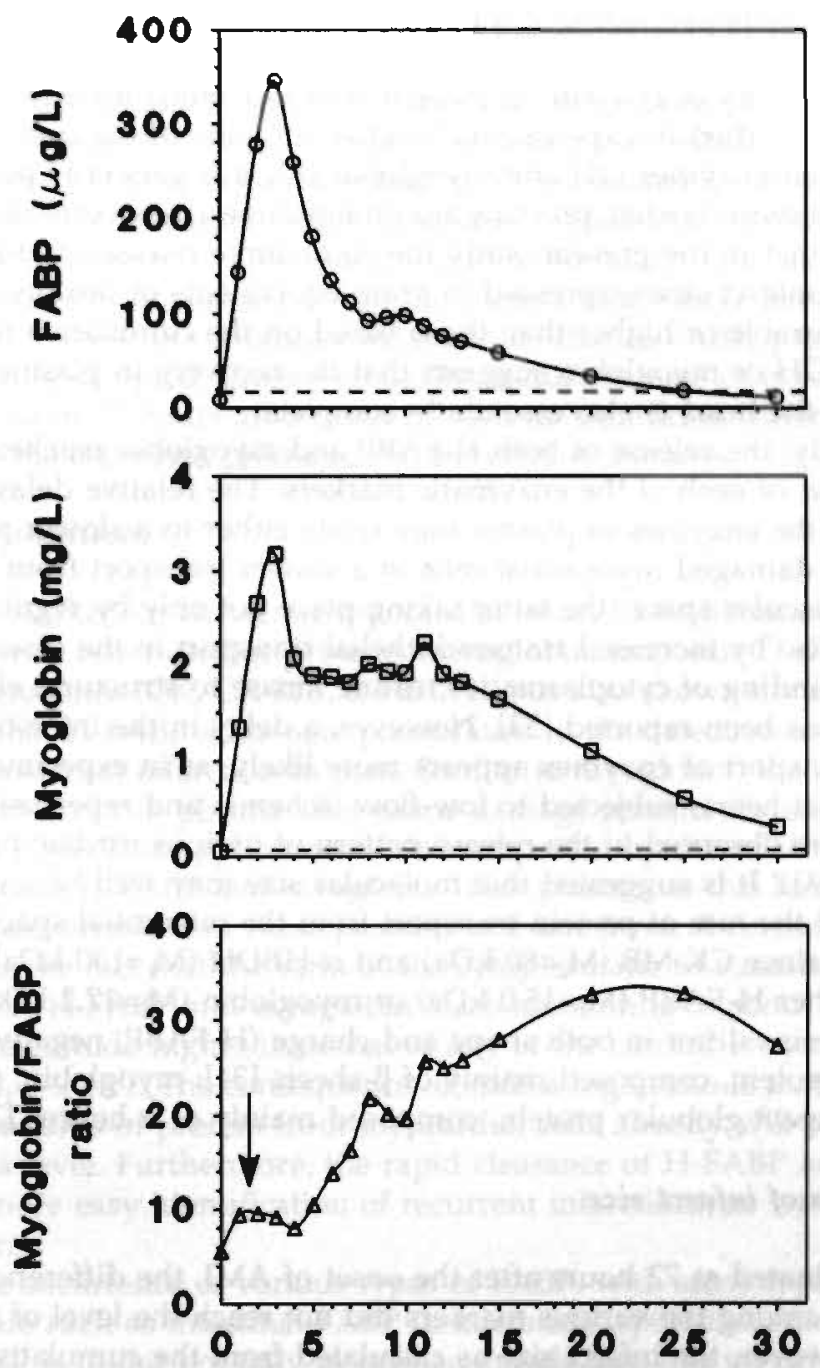

Time after first onset of AMI (hours)

Figure 6.7. Plasma concentrations of H-FABP and myoglobin, and the plasma myoglobin/H-FABP ratio as function of time after AMI in a patient who was defibrillated shortly after admission to the hospital (see arrow in lowest panel). Dotted lines indicate threshold level of H-FABP and assay detection limit for myoglobin (see text for details). 


\section{Recovery of H-FABP in plasma after ischaemic myocardial damage.}

For both the myocardial enzymes CK-MB and $\alpha-\mathrm{HBDH}$ [31] and myoglobin [27] it has been demonstrated that the total quantities of protein depleted from dog heart after coronary occlusion equal the calculated release of these proteins into plasma. The recovery of H-FABP in plasma after ischaemic myocardial injury has not yet been quantified in experimental studies. In view of the stability of the above mentioned enzymes [21] and myoglobin [32] it is generally assumed that also in humans these cardiac proteins are quantitatively recovered in plasma after AMI. The fact that in the present study the cumulative release of H-FABP yields an estimate of infarct size (expressed in gram-equivalents of healthy myocardium) which is comparable or higher than those based on the cumulative release of CK, $\mathrm{CK}-\mathrm{MB}, \alpha-\mathrm{HBDH}$ or myoglobin suggests that the recovery in plasma of H-FABP depleted from the heart is also essentially complete.

Interestingly, the release of both H-FABP and myoglobin reaches completeness earlier than that of each of the enzymatic markers. The relative delay in the appearance of the enzymes in plasma may relate either to a slower release of enzymes from damaged myocardial cells or a slower transport from the interstitial space to the vascular space (the latter taking place not only by regular lymph drainage but also by increased transendothelial transport in the diseased tissue). Evidence for binding of cytoplasmatic creatine kinase to structural elements in heart muscle has been reported [33]. However, a delay in the interstitial or transendothelial transport of enzymes appears more likely, as in experimental studies with isolated rat hearts subjected to low-flow ischemia and reperfusion no differences were observed in the release pattern of various cardiac proteins (Vork, $\mathrm{PhD}$ thesis, 1993). It is suggested that molecular size may well be a main determinant of the rate of protein transport from the interstitial space to the plasma space, since CK-MB $\left(M_{r}=80 \mathrm{kDa}\right)$ and $\alpha-\mathrm{HBDH}\left(\mathrm{M}_{\mathrm{r}}=130 \mathrm{kDa}\right)$ are much larger than either H-FABP $\left(M_{r}=15.0 \mathrm{kDa}\right)$ or myoglobin $\left(\mathrm{M}_{\mathrm{r}}=17.2 \mathrm{kDa}\right)$, while the latter two proteins differ in both shape and charge (H-FABP, negatively charged clam-shaped protein, composed mainly of $\beta$-sheets [34]; myoglobin, uncharged, extremely compact globular protein, composed mainly of $\alpha$-helices [35]).

\section{Estimation of infarct size.}

When evaluated at 72 hours after the onset of AMI, the differences in estimates of infarct size among the various markers did not reach the level of significance (Fig. 6.5.). However, the infarct size as calculated from the cumulative release of $\mathbf{H}$ FABP unmistakably tended to be higher. The exact reason for this tendency is unknown, but several possible explanations can be offered. Firstly, the true FCR of H-FABP might be lower than that of myoglobin, possibly as a result of differences in physico-chemical properties between the two proteins. It is known that the isoelectric point of a compound influences the manner by which it is handled by the kidneys [36]. The different iso-electric points of myoglobin and H-FABP (7 and 5.1, respectively) make that, at physiological $\mathrm{pH}, \mathrm{H}-\mathrm{FABP}$ is more negatively charged, causing H-FABP to stay longer in the circulation than myoglobin, which leads to a lower (i.e. an underestimated) FCR of H-FABP. This in turn will lead to an over- 
estimation of the calculated infarct size. Secondly, the myocardial contents of $\mathbf{H}$ FABP and myoglobin were measured in left ventricular tissue only and in a limited group of subjects $(n=17)$. We can not exclude that differences exist between left and right ventricular tissue, with regard to the contents of H-FABP and myoglobin. This may also have led to over- or under-estimation of calculated infarct sizes. Thirdly, H-FABP and myoglobin each have been measured using a immunochemical assay (i.e. measurement of protein mass), while the enzymes (CK, CK-MB and $\alpha-\mathrm{HBDH}$ ) have been measured by their enzymatic activity. For CK-MB it has been found that measurement in plasma of protein mass is more reliable than measurement of activity [37], indicating that the infarct sizes as calculated from the measurement of enzyme activity in plasma might have been underestimated. Despite these uncertainties we conclude that H-FABP, provided that blood is frequently sampled, gives a clinically useful estimate of nnyocardial infarction size, since $\mathbf{7 2}$ hours after onset of AMI no significant differences were found between the estimates produced by the various markers.

\section{Clinical application.}

As plasma marker for ischaemic myocardial injury H-FABP shares several characteristics with other cardiac proteins (myoglobin, troponin $\mathrm{T}$ ) and with cardiospecific enzymes (CK, CK-MB, $\alpha-\mathrm{HBDH}$ ), but also shows some unique differences so that H-FABP adds new possibilities to the detection and evaluation of an acute myocardial infarction in man. Similar to myoglobin, the rapid appearance of H-FABP in plasma after tissue damage permits the early assessment or exclusion of AMI. This application is also supported by the relatively rapid elimination of both H-FABP and myoglobin from plasma, as this keeps steady state plasma concentrations of these proteins at a low level. A further illustration of this notion is the fact that the ratio of the cytoplasmatic to vascular concentrations of H-FABP and myoglobin (each amounting to about $2 \times 10^{5}$ ) are one order of magnitude higher than that of any of the cardiac enzymes (e.g. CK, 6 $\times 10^{4} ; \alpha-\mathrm{HBDH}, 5 \times 10^{3}$ ). The consequence of such a high ratio is that the release of only minute amounts of protein from myocardial cells already will significantly raise its plasma level. Furthermore, the rapid clearance of H-FABP and myoglobin also allows a more easy identification of recurrent infarctions, as was exemplified in this Chapter.

Despite the occurrence of various types of FABP, with some types solely found in a single tissue such as intestinal-FABP in interstitial epithelial cells [38,39], heart-type FABP is found not only in cardiac muscle but, like myoglobin, also in striated skeletal muscle [40]. However, the myoglobin/H-FABP content of human skeletal muscle is $32-70$ (depending on the muscle fibre type composition, see ref. 41) and that of heart $4.9 \pm 1.2$ (this Chapter), making H-FABP more cardiospecific than myoglobin. Since H-FABP and myoglobin show similar patterns of release from tissue and elimination from plasma, the plasma myoglobin/H-FABP ratio will allow a discrimination between cardiac and skeletal muscle damage. In the patients described in this study we observed a myoglobin/H-FABP ratio of 3.6-5.5, while in a patient with AMI who was defibrillated soon after admission to hospital 
we found the plasma myoglobin/H-FABP ratio to increase steadily to a value of 28 upon this inter-vention (Fig. 6.7.).

Various conditions may cause erroneous values of plasma H-FABP. For instance, in case of decreased glomerular filtration rate (GFR) the H-FABP released from damaged myocardial tissue will accumulate in the plasma, thus leading to a possible overestimation of infarct size (see Chapter 5). This conclusion holds also for myoglobin.

The rapid release of H-FABP into plasma enables a reliable estimation of myocardial infarct size already 24 hours after AMI. However, this application has to meet two conditions. Firstly, sufficient plasma samples have to be obtained during the first day of hospitalization. Secondly, it should be emphasised that the use of the FABP plasma concentration as an early diagnostic tool of AMI requires a fast assay system. This is not yet possible (the sandwich ELISA used in the present study takes a few hours to complete), but recent developments in the field of immunodiagnostic tests [41] will permit the generation of a sensitive assay for plasma H-FABP which yields quantitative data within minutes. In addition, immunochemical detection of proteins in plasma is generally considered to be advantageous as it is free from problems inherent to the measurement of enzyme activity of proteins.

\subsection{SUMMARY.}

Cytoplasmatic heart-type fatty acid-binding protein (H- FABP) is a $15 \mathrm{kDa}$ protein abundantly present in myocardial tissue. Upon ischemia H-FABP is rapidly released into plasma, indicating that this protein can be used as a biochemical marker for ischaemic myocardial injury. In 49 patients with acute myocardial infarction (AMI), all receiving thrombolytic therapy within 6 hours after AMI, we studied the completeness of the release of H-FABP from damaged tissue and the suitability of serial plasma H-FABP concentrations for estimation of myocardial infarct size. For comparison, myoglobin, creatine kinase (CK), CK-MB and alfahydroxybutyrate dehydrogenase $(\alpha-\mathrm{HBDH})$ were also studied. Since the pattern of immunochemically assayed release of H-FABP into plasma was similar to that of myoglobin, and the plasma myoglobin to H-FABP ratio remained constant over 72 hours after AMI, cumulative release into plasma of H-FABP was calculated using a circulatory model validated for myoglobin, i.e. a one-compartment model with a fractional catabolic rate (FCR) of elimination from plasma of $2.6 \mathrm{~h}^{-1}$. Release of both H-FABP and myoglobin was completed earlier (24-36 hours) than that of CK and CK-MB ( $50-70$ hours) and that of $\alpha-\mathrm{HBDH}$ ( $>70$ hours). However, infarct size estimated from the cumulative release of the proteins, 48 hours after the onset of AMI, and expressed as gram-equivalents ( $\mathrm{g}$-eq) of healthy myocardium per litre of plasma, yielded comparable values when expressed as gram- equivalents of tissue per litre plasma for each of the proteins and enzyme activities. These data indicate that H-FABP released from the heart after AMI is quantitatively recovered in plasma and that H-FABP is a useful biochemical plasma marker for the estimation of myocardial infarct size in man. 


\subsection{REFERENCES.}

1. Willems GM, Muijtjens AMM, Lambi FHH, Hermens WTh: Estimation of circulatory parameters in patients with acute myocardial infarction. Significance for calculation of enzymatic infaret size. Cardiovasc Res 13: 578-587, 1979.

2. Van der Veen FH, Visser R, Willems GM, Kop-Klaassen B, Hermens WTh: Myocardial enzyme depletion in infarcted human hearts: infarct size and equivalent tissue mass. Cardiovasc Res 22: 611619, 1988.

3. Stone MJ, Waterman MR, Harimoto D, Murray G, Wilson N, Platt MR, Blomquist G, Willerson IT: Serum myoglobin level as diagnostic test in patients with acute myocardial infarction. Br Heart I 39: 375-380, 1977.

4. Varkd AP, Roby DS, Watts $\mathrm{H}$, Zatuchni J: Serum myoglobin in acute myocardial infaretion: A clinical study and review of the literature. Am Heart / 96: 680-688, 1978.

5. Drexel H, Dworzak E, Kirchmair W, Milz MM, Puschendorf B, Dienstl F. Myoglobinemin in the early phase of acute myocardial infarction. Am Heart J 105: 642-651, 1983.

6. McComb JM, McMaster EA, Mackenzie G, Adgey AA]: Myoglobin and creatine kinase in acute myocardial infarction. Br Heart / 51: 189-194, 1984.

7. Isakov A, Shapira I, Burke $M, A \operatorname{lmog} C$ : Serum myoglobin levels in patients with ischernic myocardial insult. Arch Intern Med 148: 1762-1765, 1988.

8. Katus HA, Remppis A, Looser S, Hallermeier K, Scheffold T, Kübler W: Enzyme linked immuno assay of cardiac troponin $\mathrm{T}$ for the detection of acute myocardial infarction in patients. / Mol Cell Cardiol 21: 1349-1353, 1989.

9. Katus HA, Looser S, Hallermayer K, Remppis A, Scheffold T, Borgya A, Essig U, GeuB U: Development and in vitro characterization of a new immunoassay of cardiac troponin $\mathrm{T}$. Clin Chem 38: 386-393 1992.

10. Ellis KA, Litle T, Masud Z, Liberman HA, Morris DC, Klocke FIP: Early noninvasive detection of successful reperfusion in patients with acute myocardial infarction. Circulation 78: 1352-1357, 1988.

11. Katus HA, Diederich KW, Scheffold T, Uellner M, Schwarz F, Kübler W: Non-invasive assessment of infarct reperfusion: the predictive power of the time to peak value of myoglobin, CK-MB and CK in serum. Eur Heart J 9: 619-624, 1988.

12. Hermens WT, Van Dieijen-Visser MP, Kleine AH, van der Wieken LR, Simoons ML: Identical estimates of myocardial infarct size from myoglobin and from enzymes in plasma. submitted.

13. De Zwaan Ch, Willems GM, Vermeer F, Res J, Verheugt FWA, Van der Laarse A, Simoons ML, Lubsen J, Hermens WTh: Enzyme tests in the evaluation of thrombolysis in acute myocardial infarction. Br Heart J 59: 175-183, 1988.

14. Glatz JFC, Van Bilsen M, Paulussen RJA, Veerkamp JH, Van der Vusse GJ, Reneman RS: Release of fatty acid-binding protein from isolated rat heart subjected to ischemia and reperfusion or to the calcium paradox. Biochim Biophys Acta 961: 148-152, 1988.

15. Knowlton AA, Apstein CS, Saouf R, Brecher P: Leakage of heart fatty acid-binding protein with ischemia and reperfusion in the rat. / Mol Cell Cardiol 21: 577-583, 1989.

16. Knowlton AA, Burrier RE, Brecher P: Rabbit heart fatty acid-binding protein. Isolation, characterization, and application of a monoclonal antibody. Circ Res 65: 981-988, 1989.

17. Glatz JFC, Van der Vusse GJ: Cellular fatty acid-binding proteins: Current concepts and future directions. Mol Cell Biochem 98: 237-251, 1990.

18. Veerkamp JH, Peeters RA, Maatman RGHJ: Structural and functional features of different types of cytoplasmatic fatty acid-binding proteins. Biochim Biophys Acta 1081: 1-24, 1991.

19. Tanaka T, Hirota $Y$, Sohmiya K-I, Nishimura S, Kawamura K: Serum and urinary heart fatty acid-binding protein in acute myocardial infarction. Clin Biochem 24: 195-201, 1991.

20. Van der Wieken LR, Nijssen KM, Simoons ML: Ridogrel as an adjunct to thrombolysis in acute myocardial infarction. Submitted.

21. Van der Laarse A, Dijkshoorn NJ, Hollaar L, Caspers T: The (iso-)enzyme activities of lactate dehydrogenase, alphahydroxybutyrate dehydrogenase, creatine kinase and aspartate aminotransferase in human myocardial biopsies and autopsies. Clin Chim Acta 104: 381-391, 1980.

22. Hermens WTh, Willems GM, Davids HA, Hollaar L, Vander Laarse A: Enzymatic assessment of myocardial injury after infarction or cardiac surgery. Is isoenzyme analysis required? Clin Chim Acta 156: 235-246, 1986. 
23. Delanghe J, Chapelle JP, Magdeleine EA, De Buyzere M: Quantitative turbidimetric assay for determining myoglobin evaluated. Ann Clin Biochem 28: 474-479, 1991.

24. Willems GM, Visser MP, Krill MTA, Hermens WTh: Quantitative analysis of plasma enzyme levels based on simultaneous determination of different enzymes. Cardiooasc Res 16: 120-131, 1982.

25. Willems GM, Muytjens AMM, Lambi FHH, Hermens WTh: Estimation of circulatory parameters in patients with acute myocardial infarction. Significance for calculation of enzymatic infarct size. Cardiovasc Res 13: 578-587, 1979.

26. Groth $\mathrm{T}$, Sylvèn C: Myoglobin kinetics in patients suffering from acute myocardial infarction in its early phase - as studied by the single injection method. Scand J Clin Lab Inoest 41: 79-85, 1981.

27. Ellis AK, Saran BR: Kinetics of myoglobin release and prediction of myocardial depletion after coronary artery reperfusion. Circulation 80: 676-683, 1989.

28. Toujl R, Tanaka T, Somiya K, Yoshimoto K, Hirota Y, Kawamura K: Canine heart fatty acidbinding protein (ch-FABP). Purification and kinetic studies. I Mol Cell Cardiol 24: S183, 1992.

29. Börchers $T$, Unterberg $C$, Rüdel $H$, Robenek $H$, Spener F: Subcellular distribution of cardiac fatty acid-binding protein in bovine heart muscle and quantitation with an enzyme-linked immunosorbent assay. Biochim Biophys Acta 1002: 54-61, 1989.

30. Unterberg C, Börchers T, Hejrup P, Roepstroff P, Knudsen J, Spener F: Cardiac fatty acid-binding proteins. Isolation and characterization of the mitochondrial fatty acid-binding protein and its structural relationship with the cytosolic isoforms. J Biol Chem 265: 16255-16261, 1990.

31. Hermens WT, Van der Veen FH, Willems GM, Mullers-Boumans ML, Schrijvers-Van Schendel A, Reneman RS: Complete recovery in plasma of enzymes lost from the heart after permanent coronary occlusion in the dog. Circulation 81: 649-659, 1990.

32. Johnson RN, Sammel NL, Norris RM: Depletion of myocardial creatine kinase, lactate dehydrogenase, myoglobin and $\mathrm{K}^{*}$ after coronary artery ligation in dogs. Cardiovasc Res 15: 529-537, 1982.

33. Othway JH: Evidence for binding of cytoplasmic creatine kinase to structural elements in heart muscle. Nature 215: 521-522, 1967.

34. Zanott G, Scapin G, Spadon P, Veerkamp JH, Sacchettini JC: Three-dimensional structure of recombinant human muscle fatty acid-binding protein. I Biol Chem 267: 18541-18550, 1992.

35. Stryer L: In: Biochemistry, WH Freeman and Co (Eds), New York, pp 145-146, 1988.

36. Guyton AC: In: Textbook of medical physiology, MJ Wonsiewicz (Ed), WB Saunders Company, Philadelphia, pp 290-297, 1991.

37. Elisenberg PR, Shaw D, Schaab C, Jaffe AS: Concordance of creatine kinase-MB activity and mass. Clin Chern 35: 440-443, 1989.

38. Sacchettini JC, Hauft SM, Van Camp SL, Cistola DP, Gordon JI: Developmental and structural studies of an intracellular lipid binding protein in the ileal epithelium. J Biol Chem 265: 19199$19207,1990$.

39. Kanda $T$, Nakatomi $Y$, Ishikawa $H$, Hitomi $M$, Matsubara $Y$, Ono $T$, Muto $T$ : Intestinal fatty acid-binding protein as a sensitive marker of intestinal ischemia. Digest Dis Sci 37: 1362-1367, 1992.

40. Peeters RA, Veerkamp JH, Van Kessel AG, Kanda T, Ono T: Cloning of the cDNA encoding human skeletal-muscle fatty-acid-binding protein, its peptide sequence and chromosomal localization. Biochem / 276: 203-207, 1991.

41. Van Nieuwenhoven FA, Kleine AH, Keizer HA, Van Diejen MP, Van Der Vusse GJ, Glatz JFC: Comparison of myoglobin and fatty acid-binding protein as plasma markers for muscle damage in man. Eur / Physiol (Pfligers Arch) 421: R 40, 1992.

42. Newman JD, Turner APF: Biosensors: principles and practice. Essays in Biochem 27:147-159, 1992. 
CHAPTER 7

\section{IMMUNOHISTOCHEMICAL DETECTION OF VERY RECENT MYOCARDIAL INFARCTIONS IN MAN WITH ANTIBODIES AGAINST HEART-TYPE FATTY ACID-BINDING PROTEIN ${ }^{*}$}

7.1. Introduction $\mathrm{p} 90$

7.2. Material and methods p 90

7.3. Results p 92

7.4. Discussion p 92

7.5. Summary p 94

7.6. References p 97

- Adapted from: Kleine AH, Glatz JFC, Havenith MG, Van Nieuwenhoven FA, Van der Vusse GJ, Bosman FT: Immunohistochemical detection of very recent myocardial infarctions in man with antibodies against heart type fatty acid-binding protein. Cardiovasc Pathol 2: 63-69, 1993. 


\subsection{INTRODUCTION.}

With conventional histochemical staining techniques acute myocardial infarction (AMI) can be detected in myocardial tissue from 6 hours after the onset of ischemia. From 4 hours after onset of ischemia detection of AMI is feasible with microscopic and/or macroscopic enzyme-histochemical nitroblue tetrazolium (NBT) staining. This technique is based on visualization of the activity in myocardial tissue of intracellular dehydrogenates through the activity of nicotinamide adenine diaphorase (NADHd) [1,2]. Reduction of NBT causes the formation of a blue insoluble pigment (formazan), which reflects the intracellular activity of dehydrogenates in non-infarcted myocardial tissue. However, with the NBT-staining only infarctions with a post infarction interval of more than 4 hours can be detected with certainty. This observation is in concord with significant elevation of the plasma levels of alpha-hydroxybutyrate dehydrogenase ( $\alpha-\mathrm{HBDH}$, the cardiospecific isozyme of lactate dehydrogenase) from 5-7 hours after the onset of ischemia (Chapter 5 and 6, this thesis).

In 1988 Glatz et al. [3] introduced the cytoplasmatic heart type fatty acidbinding protein (H-FABP) as a possible early plasma marker for AMI, which assumption was soon confirmed in other studies [4,5]. Around the same time evidence was presented that after AMI H-FABP is released into the circulation from human hearts [ 6 and Chapter 5, this thesis], and that elevated H-FABP plasma levels are already detectable within 3 hours after onset of ischemia [Chapter 5, this thesis].

Since the early rise of plasma H-FABP is most likely a reflection of the depletion of this protein from ischemic and/or infarcted myocardial tissue, as is the case for essentially any protein freely present in the cytoplasm of cardiomyocytes [for review see ref. 7], H-FABP could be a valuable tool for assessing the presence of a very recent infarction in autopsy material.

In the present study the presence of H-FABP in tissue sections of infarcted human myocardium with varying post infarction intervals was immunohistochemically investigated using monospecific polyclonal rabbit IgG against human H-FABP (Chapter 2 sections 6 and 7). The immunohistochemical results were compared with those obtained by conventional haematoxylin-eosin staining and macroscopic NBT-staining of adjacent tissue sections.

\subsection{MATERIALS AND METHODS.}

Isolation and purification of H-FABP.

Human H-FABP was purified by gel permeation and anion-exchange chromatography as described in Chapter 2.

\section{Production of antibodies.}

A rabbit (Flemish giant) was immunized with $200 \mu \mathrm{g}$ of pure human H-FABP in a mixture of $2 \mathrm{ml}$ phosphate buffered saline (PBS: $137 \mathrm{mM} \mathrm{NaCl}, 2.7 \mathrm{mM} \mathrm{KCl}, 8$ 
$m M \mathrm{Na}_{2} \mathrm{HPO}_{4} 1.5 \mathrm{mM} \mathrm{KH}_{2} \mathrm{PO}_{4} \mathrm{pH}$ 7.4) and Freund's Complete Adjuvant (1:1, $v / v)$. Booster injections were given after 4 and 8 weeks with $200 \mu \mathrm{g}$ of pure antigen in a mixture of $2 \mathrm{ml} \mathrm{PBS}$ and Freund's Incomplete Adjuvant $(1: 1, \mathrm{v} / \mathrm{v})$. The rabbit was bled two weeks after the final injection. Specific antibodies against human H-FABP were isolated from plasma by a two-step affinity chromatography procedure as described in Chapter 2 section 7. Specificity of the antibodies was tested in an indirect enzyme-linked immunosorbent assay 18 and Chapter 3 section 2 , this thesis].

\section{Tissues.}

All tissue samples were obtained from 25 autopsy cases retrieved from the archives of the department of Pathology (head: J.W. Arends) of the Academic Hospital Maastricht (Maastricht, the Netherlands). In 23 cases (16 males, 7 females) cardiac death was clinically diagnosed, and in 2 cases (1 male, 1 female) the mode of death was clinically established to have been non cardiac. The males ranged in age from 36 to 86 years (62.4 years on average), the females from 22 to 88 years (67.9 years on average). In each case an approximately $0.75 \mathrm{~cm}$ thick transverse section of the heart, located halfway between the apex and the annulus and parallel to the atrio-ventricular sulcus, was taken out for NBT-staining. Tissue samples were collected from the adjacent part of the heart. From the left ventricular posterior, lateral and anterior wall and septum, and from the right ventricle wall samples, including the main perfusion areas of the main coronary arteries, were taken. Some myocardial tissue samples showed old and recent infarction, allowing for more than one observation per section. As a result the number of observed infarcted areas is larger than the number of autopsy cases studied and the total sum of sections (see Table 7.1.).

For immunostaining and routine histochemical staining tissue samples were fixed in $4 \%$ neutral buffered formaldehyde for at least 24 hours. Subsequently, the tissue samples were routinely processed and embedded in paraffin as described in Chapter 2 section 9.

\section{Immuno- and enzymehistochemical staining.}

Tissue sections ( $3 \mu \mathrm{m}$ thick) were deparaffinized and rehydrated. Endogenous peroxidase activity was blocked with $0.2 \% \mathrm{H}_{2} \mathrm{O}_{2}$ in methanol. Tissue sections were incubated with monospecific polyclonal rabbit IgG against human H-FABP $(0.8 \mathrm{mg}$ $\mathrm{IgG/I}$ ) diluted 1:250 in PBS, supplemented with $0.1 \%(\mathrm{w} / \mathrm{v})$ bovine serum albumin and $0.1 \%(\mathrm{v} / \mathrm{v})$ Tween-20 (PBT). Subsequently, 1:250 diluted swine-anti-rabbit IgG conjugated with horseradish peroxidase was applied. The chromogen diaminobenzidine was used as substrate. Tissue sections were weakly counterstained with haematoxylin. The macroscopic enzyme-histochemical NBT-staining of the myocardial sections was performed according to Kubát [9]. The reader may find a more detailed description of the immuno- and enzyme-histochemical staining in Chapter 2 section 9. 

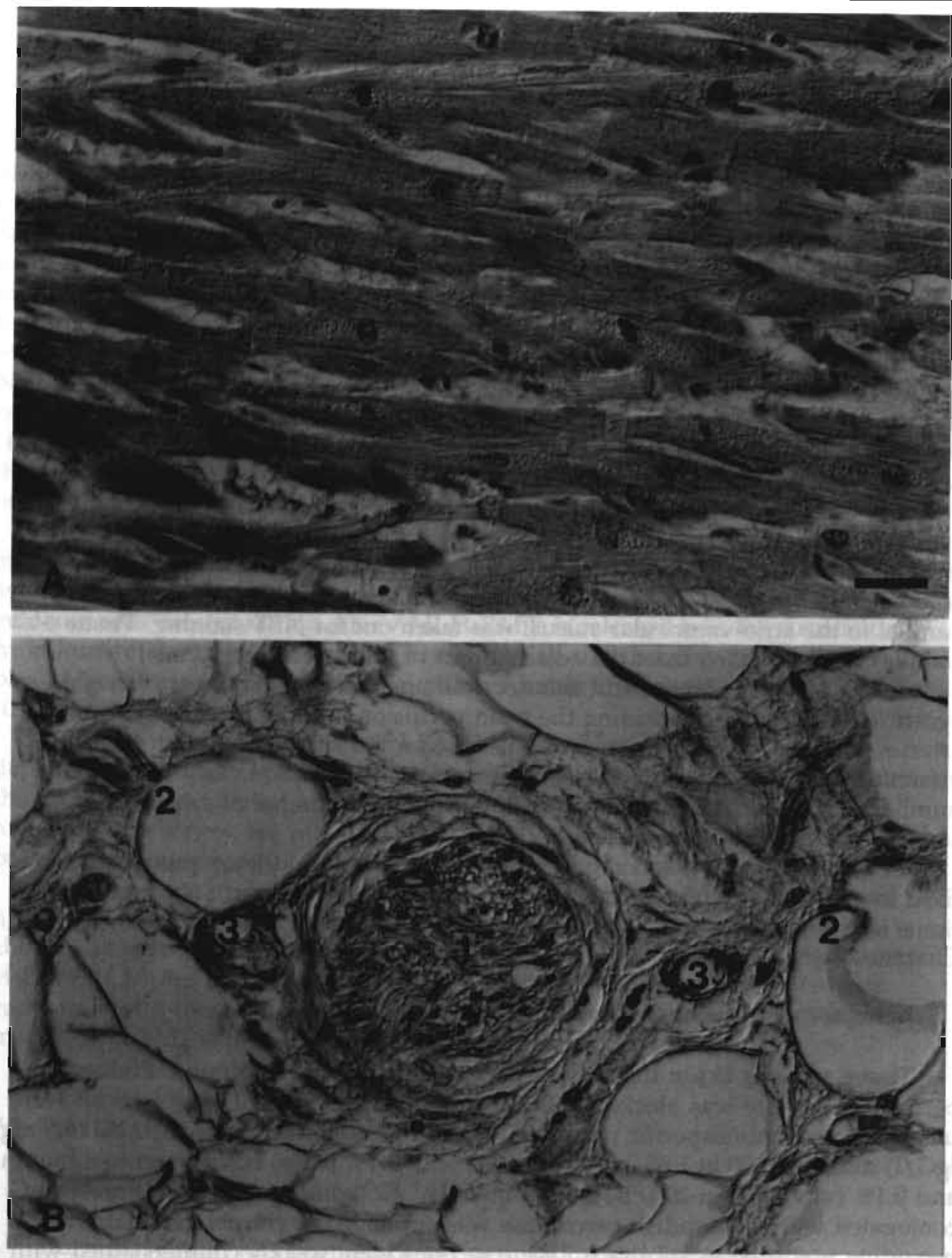

Figure 7.1. (left page) Immunoreactivity of anti H-FABP antibodies in various types of tissue in the human myocardium. Panel A: Positive immunoreactivity in vital cardiomyocytes. No immunoreactivity was seen in the connective tissue. Panel B: Positive immunoreactivity in Schwann cells of a peripheral nerve (1), in fat cells (2) and in the smooth muscle cells of a blood vessel (3). Bar in panel A represents $25 \mathrm{nM}$ in all panels.

Figure 7.2.A-B (right page) Immunoreactivity of anti-FABP antibodies in infarcted areas of 


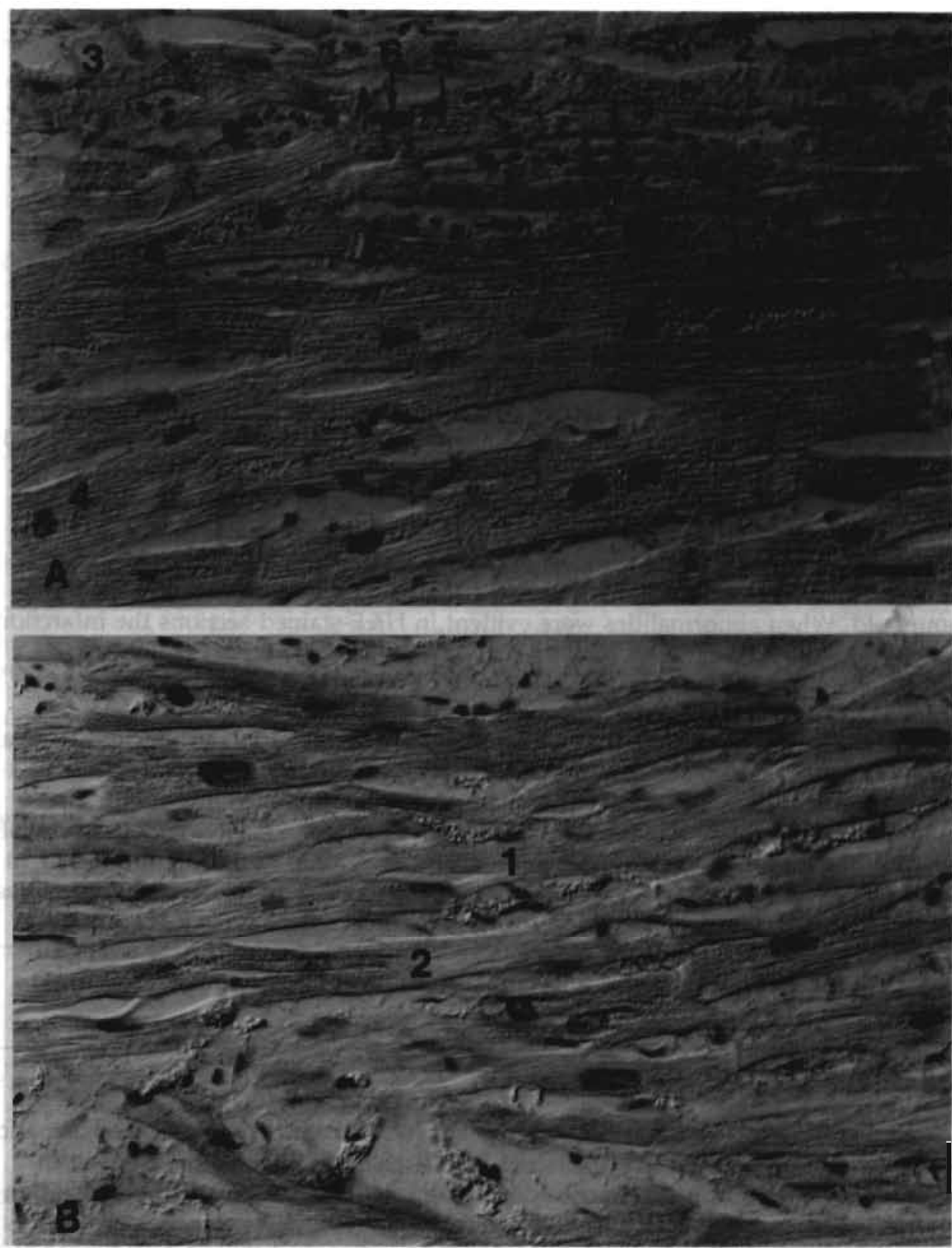

varying age in human cardiac tissue. Panel A: Infarction with a post infarction interval of more than 6 hours. Depletion of H-FABP from cardiomyocytes (1) corresponds with histological changes (2, infiltration of granulocytes). A sharp line of demarcation, parallel to the fibre orientation, is visible between infarcted (3) and still vital (4) myocardium. Accumulated lipofuscin in depleted cells (5), visible in the vicinity of the nucleus (6). Lipofuscin is visible in a H\&E-staining, FABP is not (H\&Estaining not shown). Panel B: Infarction with a post infarction interval between 4 and 6 hours.

Cardiomyocytes are totally (1) or partially (2) depleted, but no clear histological changes are visible. Bar in panel $A$ represents $25 \mathrm{nM}$ in all panels. 


\subsection{Results.}

\section{Tissue specifity of anti H-FABP antibody.}

Fig. 7.1A shows a routine immunohistochemical FABP staining of human heart. The anti H-FABP antibodies reacted with cardiomyocytes and also with smooth muscle cells of blood-vessels (Fig. 7.1A.). Furthermore, fat cells showed weak immunostaining around the nucleus (Fig. 7.1B). Immunoreactivity could also be observed in Schwann cells (Fig. 7.1B).

\section{Antibody specificity in infarcted myocardial tissue.}

The immunohistochemical results obtained on infarcted myocardium at varying post infarction time intervals are summarized in the Table 7.1. In total 100 infarcted areas were studied in 92 tissue sections from 23 autopsy cases. The post infarction interval, the period of time from onset of ischemia until the moment of death, was estimated using conventional (enzyme-) histochemical methods. When an infarction was identified through decreased NBT-staining, without histological abnormalities in H\&E-stained sections, the infarction was considered to be 4 to 6 hours old. When abnormalities were evident in H\&E-stained sections the infarction was considered to be at least 6 hours old. In cases of normal NBT-staining and normal histology the infarction was taken to be less than 4 hours old or even absent [ 2 and Table 7.2.].

The data (Table 7.1.; Fig. 7.2A) show that in myocardial infarctions with a post infarction interval of more than 6 hours H-FABP immunoreactivity was decreased or absent in cardiomyocytes in all infarctions studied. Infarcted areas with a post infarction interval between 4 and 6 hours in all cases also showed reduced or total absence of cardiomyocyte H-FABP immunoreactivity (Fig. 7.2B). In addition, in 20 infarcted areas (in 12 cases) both NBT- and H\&E-staining showed no abnormalities but there was diminished or no H-FABP immunoreactivity (Table 7.1;; Fig. 7.2C).

The two non cardiac death cases showed homogeneous H-FABP staining of myocardial tissue (cf. Fig.7.1A), and normal NBT- and H\&E-staining.

\subsection{Discussion.}

Earlier investigations have revealed that several distinct types of cytoplasmatic fatty acid-binding proteins (FABP) exist [10-12]. Although the FABP types from liver, intestine and heart show considerable differences in amino acid composition and primary structure (less than 30\% sequence homology), there can be up to 5\% mutual cross-reactivity of polyclonal antisera raised against these FABP types [13, 14]. Other FABP types, recently detected in adipose tissue [15] and nerve tissue $[16,17]$ show a high degree of sequence homology, both mutually and with heart FABP. These common sequences can comprise of one or more immunodominant epitopes, which would explain the observed reaction of the monospecific poly clonal rabbit antibodies (IgG) against H-FABP not only with cardiomyocytes, but also with other structures present in the human heart (Schwann cells and fat cells). 
The predominantly perinuclear immunostaining of fat cells can be explained by the fact that the fat globule fills up almost the entire cell, leaving only a very narrow cytoplasmatic rim which might be too narrow to recognize any immunostaining. The reaction of the monospecific polyclonal rabbit antibodies with vascular smooth muscle cells suggests that a H-FABP-like protein, sharing at least one epitope with the human H-FABP, is present in these cells.

Table 7.1. Immunoreactivity of anti-FABP antibodies in cardiomyocytes in infarcted areas of varying age in human cardiac tissue

\begin{tabular}{lcccc}
$\begin{array}{c}\text { Anti H-FABP staining } \\
\text { (cardiomyocytes) }\end{array}$ & $\begin{array}{c}\text { Number of samples with combination of } \\
\text { classical staining }\end{array}$ & $\begin{array}{c}\text { Observed in number } \\
\text { of patients }\end{array}$ \\
& $\begin{array}{c}\text { NBT+,H\&E- } \\
\text { (a) }\end{array}$ & $\begin{array}{c}\text { NBT-,H\&E- } \\
\text { (b) }\end{array}$ & $\begin{array}{c}\text { NBT-,H\&E+ } \\
\text { (c) }\end{array}$ & \\
\hline$+(n=38)$ & 38 & 0 & 0 & $20 / 23$ \\
$\pm(n=4)$ & 0 & 3 & 1 & $4 / 23$ \\
$-(n=58)$ & 20 & 6 & 32 & $23 / 23$ \\
Total * of observations & $\overline{58}$ & $-\overline{9}$ & $\overline{33}$ & \\
\hline
\end{tabular}

From 23 autopsy cases, clinically diagnosed as death due to myocardial infarction, 92 tissue samples were taken ( 4 from each case) in which a total of 100 observations were made. Anti-H-FABP ntaining: + , uniform staining; \pm , decreased staining; -, no staining. NBT-staining: NBT + , normal ( $=$ no infarction); NBT-, decreased (= infarction). H\&E-staining: H\&E+, visible histological abnormalitles; H\&E-, no visible histological abnormalities. Duration of post infarction intervals, according to Kubat [2]: (a), < 4 hours or no infarction; (b), 4-6 hours; (c), > 6 hours.

Table 7.2. The estimation of the age of acute myocardial infarction (AMI) by means of Nitrobluetetrazolium (NBT-) and Haematoxylin-Eosin (H\&E-) staining

\begin{tabular}{lccccc}
\hline Age of AMI in hours & $<2$ & $2-3$ & $4-5$ & $6-7$ & $>8$ \\
\hline $\begin{array}{l}\text { NBT-staining } \\
\text { H\&E-staining }\end{array}$ & - & + & ++ & +++ & +++ \\
\hline
\end{tabular}

$\because$ no changes; + : mild changes; ++ : moderate changes; +++ distinct changes.

- Adapted from Kubát [2], with permission.

The present data strongly suggest that depletion of FABP from cardiomyocytes can be used as an immunohistochemical marker for the confirmation of very recent ( $<4$ hours old) myocardial infarction. The results of the immunohistochemical staining of tissue sections of infarcted myocardium (post infarction interval more than 4 hours) are in agreement with the results from NBT- and H\&E-staining on adjacent sections of the same hearts, as well as with the clinical diagnoses (data not shown) of myocardial infarction. In all 42 observations (23 autopsy cases) in which NBT-staining or the combination of NBT- and H\&E-staining showed the presence of myocardial infarction in tissue sections, also depletion of H-FABP from cardiomyocytes was observed. 


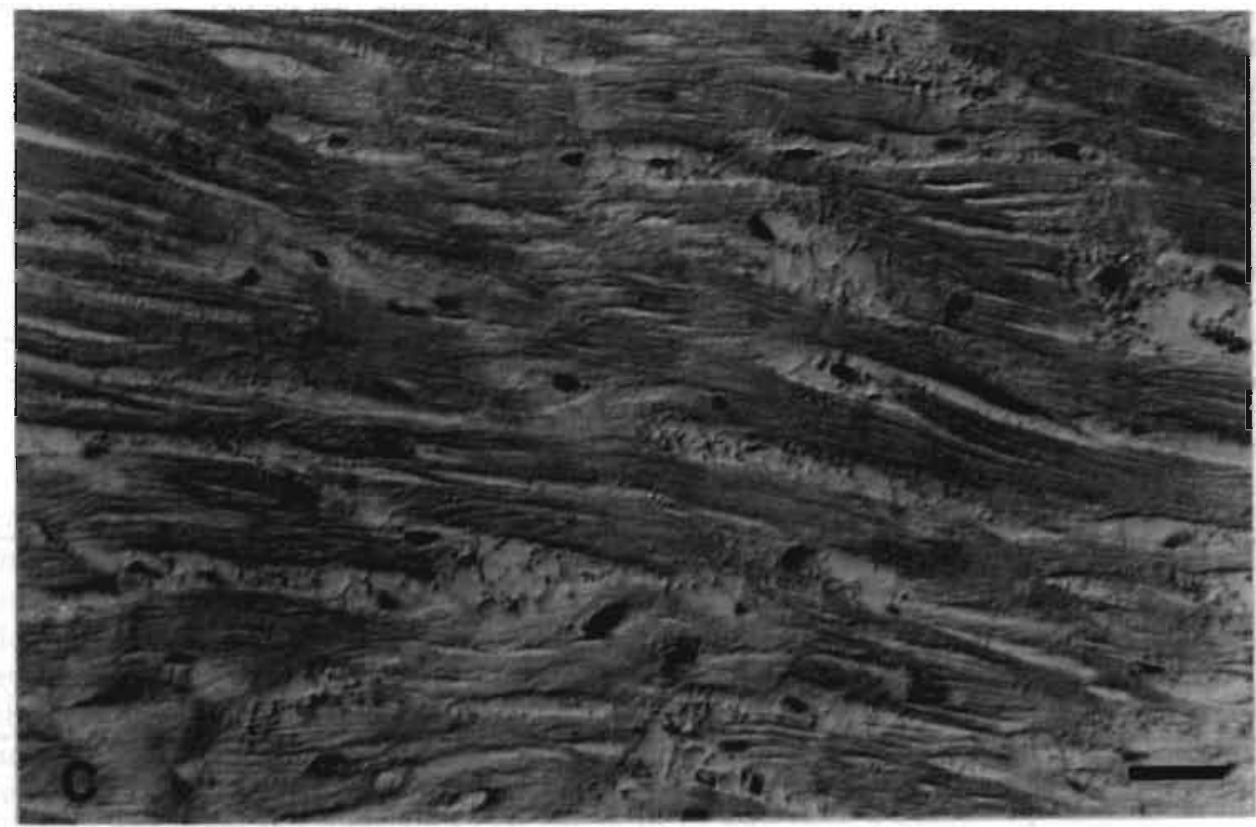

Figure 7.2.C. Infarction with a post infarction interval of less than 4 hours. Some cardiomyocytes show partial depletion. Bar represents $25 \mathrm{nM}$.

Furthermore, in 12 out of the 23 autopsy cases ( 20 observations) depletion of H-FABP was seen in regions of the heart in which NBT- and/or H\&E-staining could not confirm the clinically diagnosed infarction. This indicates that microscopic evaluation of formalin-fixed and paraffin-embedded tissue sections immunostained with anti H-FABP antibodies can detect clinically diagnosed myocardial infarctions with a post infarction interval of less than 4 hours. These observations correspond with earlier findings that increased levels of H-FABP are detected in the bloodstream within 3-4 hours after onset of first symptoms of acute myocardial infarction (see Chapter 5). Besides, the immunohistochemical results agree with data on depletion of myoglobin $\left(\mathrm{M}_{\mathrm{r}}=17.2 \mathrm{kDa}\right)$ from cardiomyocytes in experimental myocardial ischaemia in pigs [18], and thus suggest that the early depletion of H-FABP from cardiomyocytes relates to the low molecular mass $\left(\mathrm{M}_{\mathrm{r}}=15 \mathrm{kDa}\right)$ of this protein.

Since with the standard NBT-staining method detection of myocardial infarction with a post infarction interval of less than 4 hours is hardly possible, HFABP could be a valuable additional tool for confirming very recent infarction. It is an additional advantage that H-FABP immunostaining can be performed on fixed and paraffine embedded tissue sections, thus allowing for retrospective studies. In contrast to NBT-staining even individual H-FABP depleted cardiomyocytes can be visualised. Detection of small foci of very recent ischemic damage to cardiomyocytes might be useful in the studies of unexplained sudden cardiac deaths, which are most likely arrhythmic deaths. 


\subsection{SUMMARY.}

Depletion of cytoplasmatic human heart type fatty acid-binding protein (HFABP) from cardiomyocytes in infarcted areas with varying post infarction intervals was studied in 25 autopsy cases. In 23 autopsy cases myocardial infarction was clinically diagnosed as the cause of death, two cases were non-cardiac deaths and served as controls. Formaldehyde fixed and paraffin embedded myocardial tissue sections were stained immunohistochemically with antibodies to human $\mathrm{H}$ FABP. H-FABP immunohistochemical findings were compared with those from conventional nitroblue tetrazolium (NBT) macroenzyme staining and conventional histochemical haematoxylin-eosin (H\&E) staining of adjacent sections of the same infarcted areas. In all cases of infarction confirmed by NBT-staining, decreased or absent H-FABP immunostaining was observed. In 12 cases of clinically diagnosed infarction H-FABP depletion could be demonstrated in areas that showed normal NBT-staining. These findings strongly suggest that immunohistochemical staining with antibodies to H-FABP can confirm the clinical diagnosis or suspicion of early myocardial infarction. In both control cases no depletion of H-FABP was observed in cardiomyocytes in different myocardial tissue sections, macroenzyme staining with NBT was normal. In conclusion, H-FABP immunostaining may detect very recent ischemia/infarction in human myocardium and can be applied in routine autopsy pathology.

\subsection{REFERENCES.}

1. Nachlas MM, Shnitka TK: Macroscopic identification of early myocardial infarcts by alterations in dehydrogenase activity. Amer / Pathol 42: 379-397, 1963.

2. Kubát K. In: Ischemic myocardial lesions. Kubát $\mathrm{K}$ ed. Boehringer Ingelheim International GmbH, pp. 8-13, 1981.

3. Glatz JFC, van Bilsen M, Paulussen, RJA, Veerkamp JH, Van der Vusse GJ,Reneman RS: Release of fatty acid-binding protein from isolated rat heart subjected to ischemia and reperfusion or to the calcium paradox. Biochim Biophys Acta 961: 148-152, 1988.

4. Knowlton AA, Burrier RE, Brecher P: Rabbit heart fatty acid-binding protein. Isolation, characterization, and application of a monoclonal antibody. Circ Res 65: 981-998, 1989.

5. Knowlton AA, Apstein CS, Saouf R, Brecher P: Leakage of heart fatty acid binding protein with ischemia and reperfusion in the rat. / Mol Cell Cardiol 21: 577-583, 1989.

6. Tanaka T, Hirota Y, Sohmiya K-I, Nishimura S, Kawamura K: Serum and urinary human heart fatty acid-binding protein in acute myocardial infarction. Clin Biochem 24: 195-201, 1991.

7. Kupper W, Bleifeld $W$ : Serum enzyme changes in patients with cardiac diseases. In: $E$ Schmidt, FW Schmidt, I Trautschold, R Friedel eds. Advances in clinical enzymology. Basel: S Karger, pp. 106- 123, 1979.

8. Kemeny DM, Chantler S: An introduction to ELISA. In: Kemeny DM, Challacombe SJ, eds. ELISA and other solid phase immunoassays; theoretical and practical aspects. New York: John Wiley \& Sons Ltd., pp. 1-23, 1989.

9. Kubat K: On the pathological anatomy of myocardial infarction. Hart Bulletin 2: 33-40, 1971.

10. Bass NM: The cellular fatty acid binding proteins: Aspects of structure, regulation, and function. Int Reo Cytol 111: 143-184, 1988.

11. Glatz JFC, van der Vusse GJ: Cellular fatty acid-binding proteins: current concepts and future directions. Mol Cell Biochem 98: 237-251, 1990.

12. Veerkamp JH, Peeters RA, Maatman RGHJ: Structural and functional features of different types of cytoplasmic fatty acid-binding proteins. Biochim Biophys Acta 1081: 1-24,1991. 
13. Bass NM, Manning JA: Tissue expression of three structurally different fatty acid binding proteins from rat heart muscle, liver, and intestine. Biochem Biophys Res Comm 137: 929-935, 1986.

14. Paulussen RJA, Geelen MJH, Beynen AC, Veerkamp JH: Immunochemical quantitation of fattyacid-binding proteins. I. Tissue and intracellular distribution, postnatal development and influence of physiological conditions on rat heart and liver FABP. Biochim Biophys Acta 1001: 201-209, 1989.

15. Matarese V, Bernlohr DA: Purification of murine adipocyte lipid-binding protein. / Biol Chem 263: 14544-14551, 1988.

16. Schoentgen F, Pignede G, Bonanno LM, Jolles P: Fatty-acid-binding protein from bovine brain. Amino acid sequence and some properties. Eur / Biochem 185: 35-40, 1989

17. Sacchettini JC, Said B, Schulz H, Gordon JI: Rat heart fatty acid-binding protein is highly homologous to the murine adipocyte 422 protein and the $\mathrm{P} 2$ protein of peripheral nerve myelin. I Biol Chem 261: 8218-8223, 1986.

18. Fufiwara H, Tanaka M, Miyazaki S, Matsuda M, Kawai C, Fujiwara T, Onodera T, Wu D-J, Sasayama S: Detection of early myocardial infarction in formalin-fixed, paraffin-embedded tissue. Am / Cardiovasc Pathol 2: 57-61, 1988. 


\section{CHAPTER 8}

\section{GENERAL DISCUSSION}

8.1. Introduction $\mathrm{P} 100$

8.2. Immunochemical detection of H-FABP in blood plasma $p 100$

8.3. H-FABP as indicator for AMI p 101

8.4. H-FABP clearance from the circulation p 102

8.5. Quantitative assessment of myocardial tissue damage p 104

8.6. Immunohistochemical localisation of very recent myocardial infarctions p 105

8.7. Clinical applications p 106

8.8. Future directions p 107

8.9. References p 108 


\subsection{INTRODUCTION.}

Prolonged ischaemia of myocardial tissue causes an increase in the permeability of the sarcolemma for macromolecules, resulting in the release of cytoplasmatic substances into the interstitial space. The precise reason for this increased permeability is yet unknown, but generally two phases can be discerned. During the first phase, in which a general fall in ATP levels is associated with impairment of the cellular ion pumps, the sarcolemma is weakened. Enzymatic degradation of sarcolemmal phospholipids may also add to sarcolemmal destabilisation [1,2]. During the second phase, when the ischaemia develops into an infarction, the sarcolemma will be seriously damaged (overt rupture). It has also been suggested that rupture of the sarcolemmal membrane is caused by physical forces such as severe oedema, hypercontraction of the ischaemic cardiomyocytes or mechanical stress imposed upon the ischaemic cells by contracting adjacent nonischaemic cardiomyocytes. Loss of sarcolemmal integrity may also be caused by severe phospholipid degradation $[2,3]$.

From the extracellular space the released cytoplasmatic proteins eventually appear in the circulation, for the greater part via the lymphatic drainage system [4]. Analysis of the content and/or the activities of cytoplasmatic proteins in blood plasma makes detection and quantification of tissue damage possible $[5,6]$. It is generally assumed that proteins such as H-FABP are released from the cardiomyocyte during the second phase of the process mentioned above, namely when the sarcolemma is actually ruptured.

The two major findings from the studies described in this thesis are (1) measurement of the plasma content of cytoplasmatic heart fatty acid-binding protein (H-FABP) can be used for both qualitative and quantitative assessment of acute myocardial infarction (AMI) in man and (2) depletion of H-FABP from infarcted myocardial tissue can be used for immunohistochemical assessment of myocardial infarctions, even in case of post infarction intervals of less than four hours.

\subsection{IMMUNOCHEMICAL DETECTION OF H-FABP IN BLOOD PLASMA.}

To monitor H-FABP in human blood plasma a quantitative immunochemical assay was developed. We adopted a widely used and appreciated immunoassay system, namely a non-competitive enzyme-linked immunosorbent assay (ELISA) of the antigen-capture type for measurements of H-FABP content in human blood. This immunoassay is also known as the sandwich ELISA (Chapter 3). To ensure specificity of the assay concerning the detection of only H-FABP and no other specific types of FABP attempts were made to produce antibodies against antigenic and type specific parts of the H-FABP molecule. For this purpose specific antigenic oligopeptides (15-20 residues) from the human H-FABP molecule were synthesized and subsequently used as immunogens in rabbits and mice. The majority of the synthetic peptides proved to be immunogenic in both species. When tested in an antibody-capture ELISA (Chapter 3 ) the antibodies generated against the synthetic peptides (anti-SPs) were able to recognize the synthetic peptide against which they 
were directed and also the native H-FABP molecule. However, with the use of anti-SPs in various combinations no useful sandwich ELISA could be constructed for the detection of human H-FABP in biological preparations. Although the exact reason for this failure is unknown, a likely cause is the fact that three out of the four sequences of the synthetic peptides are located on the same side of the native molecule [ref. 7, and Fig. 8.1.] which may have caused the antibodies, raised against the synthetic peptides, to sterically hinder each other when used in a sandwich ELISA for detection of human H-FABP.

Further experiments showed that steric hindrance might very well have been the reason for the inability to construct a sandwich ELISA, using anti-SPs in combination with anti-FABPs. They learned that the sandwich ELISA, using monospecific polyclonal antibodies (IgG-class) against human H-FABP, was suitable for measurement of H-FABP in human plasma. Monospecific polyclonal antibodies against the human H-FABP are composed of a great number of different antibodies directed against a host of antigenic sites on the human H-FABP molecule. Thus, after the H-FABP molecule is bound by the capture antibodies (Chapter 3), there are still plenty free epitopes on the opposite side of the already bound H-FABP molecule for detector antibodies in the second antiserum to "dock".

The high sensitivity, accuracy and reproducibility of the assay, as required for clinical assays, were evident from linear calibration curves (between 0 and $5 \mathrm{pg} \mathrm{H}$ FABP), the almost complete recovery of purified H-FABP added to plasma samples in recovery experiments and the low inter- and intra-assay coefficients of variation, 7 and $4.5 \%$ respectively (Chapter 3 ).

\subsection{H-FABP AS INDICATOR FOR AMI.}

Usually the plasma activities of the cardiospecific enzymes creatine kinase MB (CK-MB) and alpha-hydroxybutyrate dehydrogenase ( $\alpha-\mathrm{HBDH})$ are used for both qualitative and quantitative assessment of AMI. The plasma level of myoglobin, the oxygen-carrying protein inside muscle cells, has also been proposed as a plasma marker for early indexation and quantification of acute myocardial infarction [10-15].

Comparison of H-FABP levels with the levels of myoglobin and the activities of CK-MB and $\alpha-\mathrm{HBDH}$ in plasma samples of patients with AMI learned that the $\mathrm{H}$-FABP as well as the myoglobin plasma levels surpassed their respective threshold values after virtually the same post infarction time interval. The plasma activities of CK-MB and $\alpha-\mathrm{HBDH}$ surpassed their respective thresholds after a longer post infarction time interval. It was therefore concluded that measurement of H-FABP and/or myoglobin is more suitable for an early indication of acute myocardial infarction in man than the normally used plasma activity measurement of CK-MB and/or $\alpha-\mathrm{HBDH}$.

Time curves showed that the H-FABP and myoglobin plasma concentrations, after peaking at $4.2 \pm 0.8$ hours after first symptoms of AMI, dropped quickly towards their threshold levels and had returned to their threshold level within 20 hours after the onset of first symptoms. In contrast the plasma activity levels of $\mathrm{CK}-\mathrm{MB}$ and $\alpha-\mathrm{HBDH}$ remained well above the threshold level until at least 25 
hours after the onset of the first symptoms (Chapters 5 and 6). The rapid clearance of H-FABP and myoglobin from the circulation is a phenomenon that allows for the demonstration of a recurrent AMI, provided that the time interval between the first and second event exceeds 5 hours. Indeed, in a cardiac patient in whom two consecutive myocardial infarctions were clinically diagnosed, the time curves of the plasma content of FABP and myoglobin showed two separate peaks (Fig. 6.4). In addition, these time courses followed exactly the same pattern, whereas from the time curves of the plasma activities of $\mathrm{CK}-\mathrm{MB}$ and $\alpha-\mathrm{HBDH}$ the occurrence of the second myocardial infarction was less clear (Chapter 6, and Fig. 6.4.). Thus, measurement of H-FABP and myoglobin plasma concentrations is not only suited for early assessment of AMI, but also for the assessment of a recurrent AMI.

Measurement of the H-FABP plasma leve] has an advantage over measurement of the myoglobin plasma level, because the myoglobin content of skeletal muscle is approximately twice that of the heart $[16,17]$ while the amount of FABP in striated muscle is only 10-50\% of that in human cardiac muscle [18]. This difference makes that, in the event that AMI and skeletal muscle damage occur simultaneously or within a few hours after each other, the influence of released skeletal muscle FABP on the estimation of the extent of myocardial injury will be less in case of an FABP-measuring assay than in a myoglobin-measuring assay. This fact was nicely illustrated in a cardiac patient who was defibrillated (cardioversion) after AMI (Fig. 5.3.). Cardioversion most likely causes damage to the pectoral and intercostal skeletal muscles resulting in release of cytoplasmatic proteins into the circulation. Because of the high myoglobin/FABP ratio in skeletal muscle (21-73, Van Nieuwenhoven and Van Dieijen-Visser, unpublished data), we detected a greater influence of cardioversion on the plasma release curve of myoglobin than on that of FABP (Fig.5.2.). Furthermore, preliminary results of studies of Van

Nieuwenhoven et al. [19] showed that upon physical exercise (endurance test) myoglobin and FABP are released into the circulation in a ratio varying from 11-41 which is comparable to the ratio (21-73) found in various types of skeletal muscle. Additionally, it was discovered that upon AMI (mere damage to cardiac tissue) myoglobin and FABP are released in a ratio of 4 to 5 which is in close accordance to the myoglobin/FABP ratio of 4 to 5 as measured in tissue specimens of the human heart [ref. 19 and Chapter 6]. Hence, assessment of this ratio in plasma can be helpful in discriminating between mere myocardial tissue damage, or myocardial tissue damage accompanied by skeletal muscle damage.

\subsection{H-FABP CLEARANCE FROM THE CIRCULATION.}

Comparison of the time curves of the plasma concentrations of FABP and myoglobin and of the plasma activities of $\mathrm{CK}-\mathrm{MB}$ and $\alpha-\mathrm{HBDH}$ revealed that FABP and myoglobin are cleared from the circulation more rapidly than are CK$\mathrm{MB}$ or $\alpha-\mathrm{HBDH}$. This phenomenon will relate to the fact that small molecules like FABP and myoglobin are easily cleared from the circulation by glomerular filtration in the kidney [20-22]. Renal clearance involves first of all the extraction of small proteins (up to $\mathrm{M}_{\mathrm{r}}$ of about $50 \mathrm{kDa}$ ) from the blood by means of glomerular filtration. 

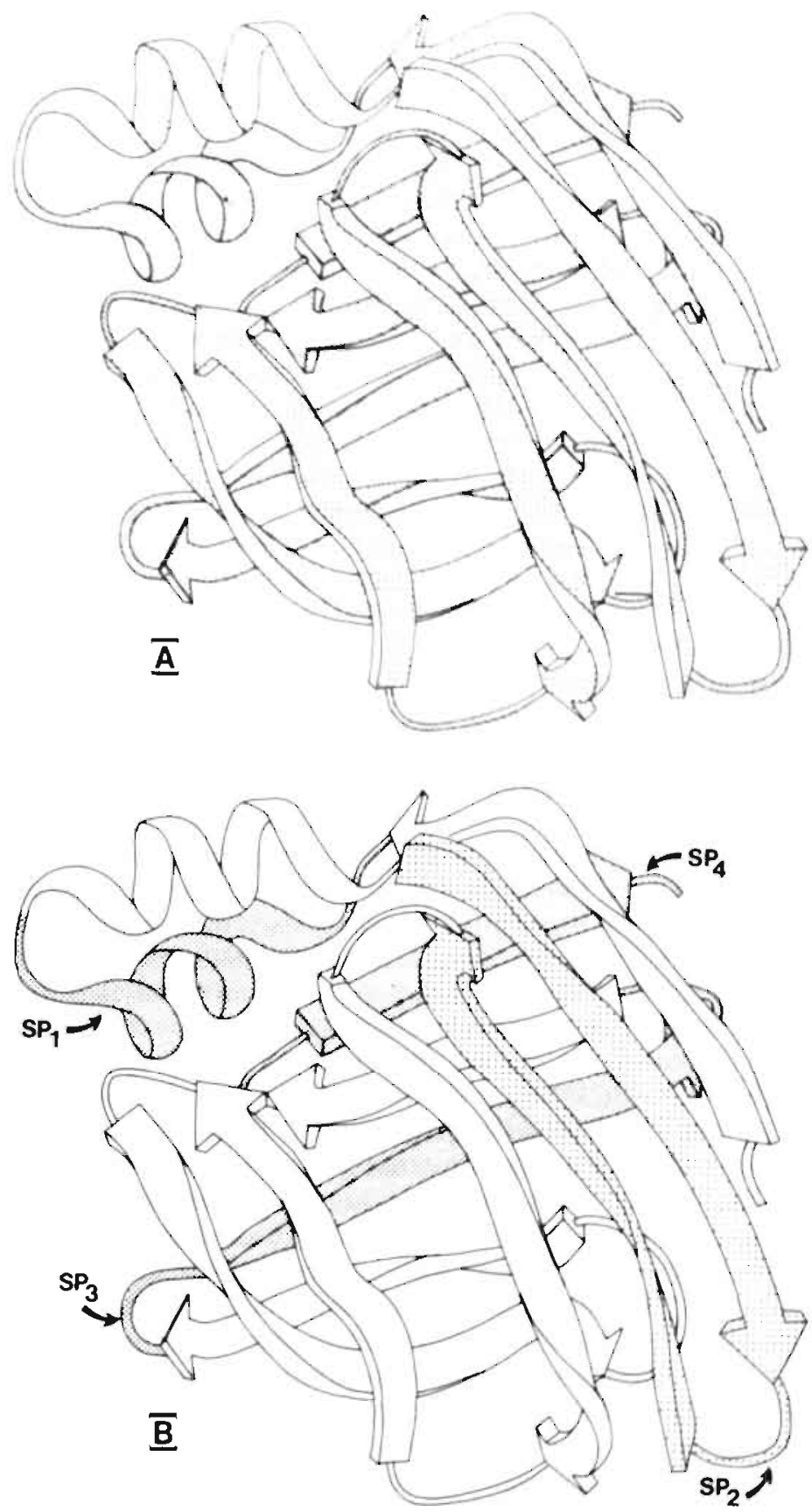

Figure 8.1. Panel A: Ribbon diagram of the rat intestinal fatty acid-binding protein molecule. Panel B: Shaded stretches on the diagram represent the locations of the synthetic peptides (SP 1-4, see Chapter 4) on the molecule. The ribbon diagram was reproduced from Sacchettini et al. [7], with permission. 
After transportation through Bowman's capsule into the renal tubular system the greater part of the proteins will be reabsorbed and, subsequently, be catabolized by the renal tubular cells [21]. Only when the reabsorptive capacity of the renal tubular system is saturated the excess of small proteins, like H-FABP and myoglobin, will be excreted into the urine. Evidence for elimination of FABP from the plasma by the kidney was found in a cardiac patient with severe impairment of renal function. The blood of this patient showed elevated plasma FABP and myoglobin levels for a prolonged period of time (Chapter 5, Fig. 5.4.). In some cardiac patients, with normal renal functions, the presence of FABP in urine could qualitatively be established, thus confirming urinary excretion of FABP, corroborating the findings by Tanaka et al. [23]. Appearance of FABP in urine after AMI might implicate that FABP levels in urine can be used as qualitative marker of AMI. To propose that FABP can be used as a quantitative urinary marker for AMI $[23,24]$ seems premature since the renal thresholds for FABP - i.e. the plasma level at which normal renal clearance mechanisms become saturated -, as well as the stability itself of FABP in an urinary environment still remain to be established.

\subsection{QUANTITATIVE ASSESSMENT OF MYOCARDIAL TISSUE DAMAGE.}

Complete time curves of the plasma contents of H-FABP and myoglobin and of the plasma activities of $\mathrm{CK}, \mathrm{CK}-\mathrm{MB}$ and $\alpha-\mathrm{HBDH}\left(\mathrm{LDH}_{1}\right)$ have been used to measure the total amount of myocardial tissue that lost its integrity after AMI (Chapter 6). It has been demonstrated that both myoglobin [25] and cardiac enzymes [26] released from the heart after AMI are completely recovered in plasma and, hence, that the cumulative release of each of these markers can be used to estimate infarct size in gram-equivalents of healthy myocardium per litre of plasma. In view of the stability of the above mentioned enzymes [27] and myoglobin [28] it is generally assumed that also in humans these cardiac proteins are quantitatively recovered in plasma after AMI. Data in Chapter 6 show that the cumulative release of $\mathrm{CK}, \mathrm{CK}-\mathrm{MB}, \alpha-\mathrm{HBDH}$, myoglobin and $\mathrm{H}-\mathrm{FABP}$ yielded comparable estimates of infarct size, indicating that H-FABP is also completely recovered in plasma after AMI. The reported general stability of FABP [29] is in support of this conclusion. It was therefore concluded that H-FABP is a useful biochemical plasma marker for the estimation of myocardial infarct size in man.

Findings, presented in Chapter 6, showed that H-FABP and myoglobin $\left(\mathrm{M}_{\mathrm{r}}=17.2 \mathrm{kDa}\right)$ simultaneously reach the circulation before CK-MB and $\alpha-\mathrm{HBDH}$. The rapid appearance of $\mathrm{H}-\mathrm{FABP}$ in the circulation, as described in Chapters 5 and 6 is a result not only of the low normal plasma level, but appears to be related to the fact that the FABP molecule $\left(\mathrm{M}_{\mathrm{r}}=15 \mathrm{kDa}\right)$ is a rather small globular protein with a diameter of approximately $45 \AA$. Findings in Chapter 6 indicated that the release of both H-FABP and myoglobin reaches completeness earlier than that of each of the measured enzymatic markers (cf. Fig. 6.5.). Experiments of Vork et al. (Vork MM, PhD thesis, 1993) with isolated working rat hearts showed that during low flow ischaemia H-FABP and LDH are released from the ischaemic cardiac tissue within the same time interval. Hence, the relative delay in the appearance of the enzymes in plasma, after release from damaged cardiomyocytes into the 
interstitial space, is indicative for a relative retardation of larger molecules $(C K$, $\mathrm{CK}-\mathrm{MB}$ and $\alpha-\mathrm{HBDH})$ during their travel through the lymphatic drainage system towards the circulation.

The constant myoglobin/H-FABP ratio in myocardial tissue $(5.0 \pm 1.1$, Chapter 6), along with the similar patterns of release from tissue and of elimination from plasma of both proteins, resulted in a constant plasma myoglobin/H-FABP ratio in patients with AMI (3.6-5.5, cf. Fig. 6.5.). Additional skeletal muscle damage, e.g. due to cardioversion (cf. Fig. 6.7.), causes an increase in the plasma myoglobin/HFABP ratio. Thus, monitoring of the plasma myoglobin/ $\mathrm{H}-\mathrm{FABP}$ ratio makes it possible to discriminate between mere myocardial tissue damage and myocardial tissue damage combined with skeletal muscle damage.

\subsection{IMMUNOHISTOCHEMICAL LOCALISATION OF (EARLY) MYOCARDIAL INFARCTIONS.}

In case of death through AMI almost always an autopsy is carried out in confirmation of the clinical diagnosis. Pathological confirmation of AMI is highly dependent on the post-infarction interval. When a patient died 6 hours or longer after the first onset of symptoms of AMI, the infarcted area of the heart shows histological changes that can be made visible with a conventional haematoxylineosin (H\&E-) staining method. When death occurs after a post-infarction interval between 4 and 6 hours the histological changes are equivocal. In those cases the nitroblue tetrazolium (NBT-) staining method [30,31] can provide clarity. This macroscopic technique reflects the intracellular activity of dehydrogenates in noninfarcted myocardial tissue. Infarcted areas with a post-infarction interval of 4 hours or more can be identified with certainty through their relative paleness compared to surrounding vital tissue. With shortening of the post-infarction interval ( $<4$ hours) the difference in staining intensity between infarcted and vital myocardial tissue becomes dubious, and myocardial infarction can not be diagnosed with certainty.

Because results from our experiments showed that the H-FABP plasma level is elevated within 3-4 hours after the first symptoms of AMI (Chapters 5 and 6), which is a direct reflection of the depletion of this cytoplasmatic protein from ischaemic and/or infarcted myocardial tissue [for review see ref. 32], we hypothesized that immunohistochemical demonstration of myocardial infarction should be possible by immunostaining the affected cardiac tissue with anti-FABPs. To test this hypothesis, results of immunohistochemical staining of assumed infarcted cardiac tissue with anti-FABPs were compared with those obtained by conventional H\&E- and NBT-staining of adjacent tissue sections. We found that in all observations, in which NBT-staining or the combination of NBT- and H\&Estaining indicated the presence of myocardial infarction in tissue sections, depletion of H-FABP from cardiomyocytes was observed. This finding strongly suggests that immunohistochemical staining with anti-FABPs can at all events confirm the clinical diagnosis or suspicion of myocardial infarction with a postinfarction interval of 4 hours or more. Furthermore, in a number of cases depletion of H-FABP was seen in regions of the heart in which NBT-and/or H\&E-staining could not confirm the clinically diagnosed infarction. This indicates that 
microscopic evaluation of formalin-fixed and paraffin-embedded tissue sections immunostained with anti-FABPs can detect infarcted areas with a post infarction interval of less than 4 hours. Furthermore, the immunohistochemical results agree with data on depletion of myoglobin from cardiomyocytes in experimental myocardial ischaemia in pigs [33], and thus suggest that the early depletion of $\mathrm{H}$ FABP from cardiomyocytes relates to the low molecular mass of this protein.

From the aforesaid results, we concluded that immunostaining of cardiac tissue sections, with the anti-FABPs which were also used in the sandwich ELISA (Chapter 5), will detect very recent ischaemia/infarction in human myocardium and thus can be applied in routine autopsy pathology. Results of the immunohistochemical experiments showed that H-FABP could be precisely located in cardiac tissue, with virtually no aspecific background staining. Because the immunostaining can be performed on formalin-fixed and paraffin-embedded tissue sections the necessity of instant evaluation of the tissue, like with the NBT-staining, becomes redundant. Besides, retrospective studies are made possible using tissue specimen from a tissue bank.

\subsection{Clinical applications.}

Measurement of the H-FABP plasma level can be useful for the early qualitative assessment of AMI in man, as was shown in this thesis. Although our H-FABP assay meets the requirements of a clinical assay, regarding specificity, precision and accuracy (Chapter 3), it has only been used in laboratory conditions up to now. It should be noted that, especially for early assessment of AMI, an assay that can be performed in a short period of time is required. Our assay, though giving reliable results, is still too much time consuming to be useful for rapid diagnosis in the clinical setting (a full assay procedure will take at least about 3 hours).

A potential disadvantage of the present technique is the fact that the outcome of the measurements of H-FABP plasma levels is dependent on a normal renal function. When glomerular filtration, for whatever reason, is impaired the raised $\mathrm{H}-\mathrm{FABP}$ plasma values might lead to misinterpretation of the seriousness of the AMI. It can be suggested that these difficulties can be overcome by measuring $\mathrm{H}$ FABP levels in urine for qualitative assessment of AMI. However, urinary H-FABP values are even more dependent on a normal renal function, and impaired glomerular filtration or tubular reabsorption might lead to false interpretations. But even when kidney function is normal, the urinary H-FABP values are difficult to interpret, because little is known about the tubular reabsorption capacity regarding H-FABP.

The assessment of the total amount of damaged myocardial tissue from the complete time curves of the plasma content of H-FABP after uncomplicated AMI (Chapter 6) seems to be fairly accurate. The calculated amounts of injured tissue are in close agreement with those calculated from the plasma time curves of myoglobin, CK-MB and $\alpha-\mathrm{HBDH}$. In the calculations it was assumed that the fractional catabolic rate (FCR) of H-FABP equals that of myoglobin. This assumption seems justified because H-FABP and myoglobin share common features (i.e. size) and because both proteins show similar plasma release curves 
after AMI. But not until the FCR of H-FABP has actually been measured, one should use values of total myocardial tissue damage (as calculated with the assumed FCR) with caution.

Skeletal muscle FABP, which is identical to heart FABP, could be a complicating factor in the assessment of AMI when AMI and skeletal muscle damage occur both within a few hours from each other. However, as experimental results showed [ref. 19 and Chapter 6], either the myocardial tissue damage has to be relatively small or the skeletal muscle damage has to be relatively extensive before the assay results will be misinterpreted. Furthermore, deviation from the myoglobin/FABP ratio of 4 to 5 - which is normally found in a plasma sample after mere myocardial damage - towards higher values is indicative of additional skeletal muscle damage.

Accurding to our experimental findings the assay for immunohistochemical assessment of recent infarctions in myocardial tissue, through depletion of H-FABP from cardiomyocytes, can be applied in routine autopsy pathology.

\subsection{FUTURE DIRECTIONS.}

The results of the studies described in this thesis gave answers to questions about the usefulness of measurement of human H-FABP plasma levels in cardiac patients for the qualitative and quantitative assessment of AMI. Furthermore, the possibility of immunohistochemical confirmation of the occurrence of AMI through the depletion of H-FABP from cardiac tissue upon AMI in man was affirmed. Nevertheless, a variety of questions remain to be answered. First we have to continue our pursuit of making the FABP-measuring assay faster, thus making its clinical use feasible. One of the possible solutions we have in mind for this problem - similar to the one suggested for the assessment of cardiac troponin $T$ [34] - is a one-step ELISA, involving ready-to-use test tubes to which only a plasma sample has to be added for instant result.

More information about the mechanism by which H-FABP is actually released from cardiomyocytes upon ischaemia and/or infarction is required. Is H-FABP, after release, immediately transported to the lymphatic drainage system and/or the circulation? To what extent does reperfusion of the ischaemic area influence the release of H-FABP? If transendothelial transport of H-FABP exists, how does this contribute to the fast appearance of H-FABP in the circulation after AMI?

Experiments with animal models and immunohistochemical analysis of ischaemic and/or infarcted human cardiac tissue are potential tools to answer these questions. The possible problem that skeletal muscle damage can give rise to misinterpretation of H-FABP plasma levels, when simultaneously occurring with AMI through, for instance, cardioversion, intramuscular injections or skeletal muscle trauma caused by a fall, also needs to be handled. Comparison of the plasma contents of various markers (e.g. the ones discussed in this thesis) in cardiac patients with and cardiac patients without known skeletal damage may be a sensible way of approaching analysis of this problem.

Studies should be carried out on how H-FABP is handled by the kidney (and/or other organs), thus possibly giving answers to questions about the FCR of H-FABP and hence to whether complete time curves of H-FABP plasma 
concentration can safely be used for calculation of total myocardial tissue damage after AMI. Study on the renal handling of FABP can also shed some light on the question whether or not urinary H-FABP levels can be used for quantitative and/ or qualitative assessment of AMI.

Regarding the loss of H-FABP from cardiomyocytes during the first four hours after onset of AMI, efforts should be made to map immunohistochemical images generated with antibodies against H-FABP - in connection with timed post infarction intervals and with the appearance of H-FABP in the circulation. In this way it might be possible to precisely determine the post infarction time interval at which H-FABP is lost from the cardiomyocytes.

In addition to its use for clinical diagnostic purposes, the use of H-FABP depletion as early marker of myocardial infarction will also be of interest for various types of experimental studies in which cardiac tissue damage may occur. Finally, the knowledge gathered from the studies described in this thesis might, in view of the existence of other tissue specific types of cytoplasmatic FABP, i.e. in liver, intestine, brain, and adipose tissue $[35,36]$, be used for the assessment of cellular injury in these tissues by a similar approach [37].

\subsection{ReFLRENCES.}

1. Jennings RB, Reimer KA: Lethal myocardial ischemic injury. Am / Path 102: 241-255, 1981.

2. Van der Vusse GJ, van Bilsen M, Reneman RS: Is phospholipid degradation a critical event in ischemia- and reperfusion-induced damage? NIPS 4: 49-53, 1989

3. Opie LH: In: The heart, Grune \& Stratton Inc, Orlando, USA, Pp. 351-371, 1986.

4. De Leiris J, Hearse DJ: Myocardial enzyme leakage as an indicator of cellular injury: principles and application. In: Methods in studying cardiac membranes Vol I. Dhalla NS. (Ed), CRC Press Inc., Boca Raton, pp. 253-277, 1984.

5. Willems GM, Muijtjens AMM, Lambi FHH, Hermens WTh: Estimation of circulatory parameters in patients with acute myocardial infarction. Significance for calculation of enzymatic infarct size. Cardionnsc Res 13: 578-587, 1979

6. Van der Veen FH, Visser R, Willems GM, Kop-Klaassen B, Hermens WTh: Myocardial enzyme depletion in infarcted human hearts: infarct size and equivalent tissue mass. Cardiouasc Res 22: 611619,1988

7. Sacchettini JC, Gordon J1, Banaszak LJ: Crystal structure of rat intestinal fatty-acid-binding protein. Refinement and analysis of the Escherichia coli-derived protein with bound palmitate. I Mol Biol 208: 327-339, 1989

8. Jameson BA, Wolf $\mathrm{H}$ : The antigenic index: a novel algorithm for predicting antigenic determinants. Cabios 4: 181-186, 1988.

9. Chou PY, Fasman R: Prediction of the secondary structure of proteins from their amino acid sequenci. Adv linzymol, 45-148, 1978.

10. Kagen LJ, Scheidt S, Butt A: Myoglobinaemia following acute myocardial infarction. Am I Med 58: $177-182,1975$

11. Stone MJ, Waterman MR, Harimoto D, Murray G, Wilson N, Platt MR, Blomqvist G, Willerson JT: Serum myoglobin level as a diagnostic test in patients with acute myocardial infarction. Br Heart ] 39: 375-380, 1977.

12. Stone MJ, Waterman MR, Poliner LR, Templeton GH, Buja M, Willerson JT: Myoglobinemia is an early and quantitative index of acute myocardial infarction. Angiology 29: 386-392, 1978.

13. McComb JM, McMaster EA, Adgey AA]: Myoglobin in the very early phase of acute myocardial infarction. Alm Clin Biochem 22: 152-155, 1985.

14. Ellis AK, Saran BR: Kinetics of myoglobin release and prediction of myocardial depletion after coronary artery reperfusion. Circulation 80: 676-683, 1989. 
15. Ohman EM, Casey C, Bengtson IR, Pryor D. Tormey W, Horgan JH: Early detection of acute myocardial infarction: additional diagnostic information from serum concentrations of myoglobin in patients without ST elevation. Br Heart / 63 335-338, 1990.

16. Sylvén C. Jansson E. Böor K: Myoglobin content in human skeletal muscle and myocardium: relation to fibre size and oxidative capacity. Cardionast Res 18:443-446, 1984 .

17. Lin L. Sylvén C. Sotonyi P, Somogyi E. Kaijser L, Jansson E: Myoglobin content and citrate synthase activity in different parts of the normal human heart. / Appl Physiol 69: 899-901, 1990.

18. PauJussen RJA, Van Moerkerk HTB, Veerkamp JH: Immunochemical quantitation of fatty acidbinding proteins. Tissue distribution of liver and heart FABP types in human and porcine tissues. Int | Biochem 22: 393-398, 1990

19. Van Nieuwenhoven FA, Kleine AH, Keizer HA, Van Dieijen MP, Van Der Vusse GJ, Glatz JFC: Release of myoglobin and tatty acid-binding protein from human cardiac or skeletal muscle upon tissue damage. Submitted.

20. Waldmann TA, Strauber W, Mogielnicki RP: The renal handling of low molecular weight piroteins. Ii.Disorders of serum protein catabolism in patients with proteinuria, the nephrotic syndrome, or uremia. / Clin Invest 51 : 2162-2174, 1972.

21. Hall CL, Hardwicke J: Low molecular weight proteinuria. Ann Rev Med 30: 199-211, 1979.

22. Klocke FJ, Copley DP, Krawczyk JA, Reichlin M: Rapid renal clearance of immunoreactive canine plasma myoglobin. Circulation 65: 1522-1528, 1982.

23. Tanaka T, Hirota Y, Sohmiya K-1. Nishimura S, Kawamura K: Serum and urinary human heart fatty acid-binding protein in acute myocardial infarction. Clin Biochem 24: 195-201, 1991.

24. Tsuji R, Tanaka T, Somiya K, Yoshimoto K, Hirota Y, Kawamura K: Canine heart fatty acidbinding protein (ch-FABP). Purification and kinetic studies. / Mol Cell Cardiol 24: S183, 1992.

25. Hermens WT, Van Dieijen-Visser MP, Kleine AH, Van der Wieken LR, Simoons ML: Identical estimates of myocardial infarct size from myoglobin and from enzymes in plasma. Submitted.

26. De Zwaan Ch, Willems GM, Vermeer F, Res J, Verheugt FWA, Van der Laarse A, Simoons Ml, Lubsen J, Hermens WTh: Enzyme tests in the evaluation of thrombolysis in acute myocardial infarction. Br Heart / 59: 175-183, 1988.

27. Van der Laarse A, Dijkshoorn NJ, Hollaar L, Caspers T: The (iso-)enzyme activities of lactate dehydrogenase, alphahydroxybutyrate dehydrogenase, creatine kinase and aspartate aminotransferase in human myocardial biopsies and autopsies. Clin Chim Acta 104: 381-391, 1980.

28. Johnson RN, Sammel NL, Norris RM: Depletion of myocardial creatine kinase, lactate dehydrogenase, myoglobin and $\mathrm{K}^{+}$after coronary artery ligation in dogs. Cordiovase Res 15: $529-537$, 1982.

29. Bass NM: The cellular fatty acid-binding proteins: Aspects of structure, regulation and function. Int Rev Cytol 111: 143-184, 1988.

30. Nachlas MM, Shnitka TK: Macroscopic identification of early myocardial infarcts by alterations in dehydrogenase activity. Amer J Pathol 42: 379-397, 1963.

31. Kubat $\mathrm{K}: \ln$ : Kubat $\mathrm{K}$ ed. Ischemic myocardial lesions. Boehringer Ingelheim International GmbH, pp. 8-13, 1981.

32. Kupper $\mathbf{W}$, Bleifeld $\mathbf{W}$ : Serum enzyme changes in patients with cardiac diseases. In: Advances in clinical enzymology. E. Schmidt, F.W. Schmidt, I. Trautshold, R. Friedel (Eds), Basel, S. Karger, pp 107-123, 1979.

33. Fujiwara H, Tanaka M, Miyazaki S, Matsuda M, Kawai C, Fujiwara T, Onodera T, Wu D-J, Sasayama S: Detection of early myocardial infarction in formalin-fixed, paraffin-embedded tissue. Am J Cardiovasc Pathol 2: 57-61, 1988.

34. Katus HA, Looser S, Hallermayer K, Remppis A, Scheffold T, Borgya A, Essig U, GeuB U: Development and in vitro characterization of a new immunoassay of cardiac troponin T. Clin Chem 38: 386-393 1992.

35. Glatz JFC, Van der Vusse GJ: Cellular fatty acid-binding proteins: Current concepts and future directions. Mol Cell Biochem 98: 237-251, 1990.

36. Veerkamp JH, Peeters RA, Maatman RCHJ: Structural and functional features of different types of cytoplasmatic fatty acid-binding proteins. Biochim Biophys Acta 1081: 1-24, 1991.

37. Kanda T, Nakatomi Y, Ishikawa H, Hitomi M, Matsubara Y, Ono T, Muto T: Intestinal fatty acid-binding protein as a sensitive marker of intestinal ischemia. Digest Dis Sci 37: 1362-1367, 1992. 


\section{SUMMARY}

After acute myocardial infarction (AMI) the appearance of myocardial cytoplasmatic components (e.g. proteins) in the bloodstream is a typical phenomenon. Due to severe damage to the sarcolemma the permeability of this membrane is increased, resulting in the release of intracellular components including proteins - into the interstitial space. From the interstitial space these proteins reach the vascular system, either directly through the endothelial cells lining the capillary wall, or via the lymphatic drainage system. It is generally accepted that plasma levels of cytoplasmatic proteins or the plasma activity levels of cytoplasmatic enzymes can be used for assessment of AMI. As shown in experiments with laboratory animals, one of the cytoplasmatic proteins that is released into the circulation after $\mathrm{AMI}$ is the non-enzymatic, heart-type fatty acidbinding protein (H-FABP).

In this thesis studies are described that were designed to establish whether or not the plasma H-FABP level can be used as a marker for the qualitative and quantitative assessment of AMI in patients with clinical indications of AMI. To this end the plasma H-FABP content was compared with those of other cytoplasmatic proteins which are currently used for assessment of tissue underperfusion (ischaemia) and/or AMI. This enabled us to better define the suitability of measurement of plasma H-FABP content for the assessment of ischaemia and/or AMI. After a general introduction about lipid transport and metabolism in the heart, the role of H-FABP therein and some basic principles of ischaemia induced damage in the heart, the outline of this thesis is described in Chapter 1.

Because of the abundant presence of the naturally circulating fatty acid-binding protein albumin in plasma, direct quantitative measurement of plasma H-FABP content through its functional capacity of binding fatty acids was not possible. After ruling out other quantitative measurements (these would require preceding extraction of H-FABP from the plasma, with the possible introduction of inaccuracies), the decision was made to develop a quantitative immunochemical assay to monitor H-FABP in human blood. The fact that there is more then one specific tissue type of FABP prompted us to synthesize oligo-peptides which corresponded with different antigenic parts of the human H-FABP molecule. These synthetic peptides where, in turn, used to raise type-specific antibodies to human H-FABP. It was expected that, when used in the immunochemical assay, these antibodies would add to the specificity of the assay. Besides a classical description of all materials and methods used for carrying out most of the experiments, the synthesis of oligo-peptides as well as the development of type-specific antibodies to human H-FABP are described in Chapter 2.

Chapter 3 contains a detailed description of immunochemical assays in general, but with emphasis on the development and validation of a quantitative immunoassay (sandwich ELISA) for the measurement of plasma H-FABP levels in human plasma. Immunochemical experiments involving the use of antibodies against synthetic peptides from the human H-FABP molecule are described in Chapter 4. The main conclusion drawn from the results in Chapter 4 is that application of antibodies against synthetic peptides (related to human H-FABP) in an immunochemical assay is not successful. In contrast, polyclonal monospecific 
antibodies against native human H-FABP were found to be useful to construct a two- antibody enzyme linked immunosorbent assay of the antigen capture type (sandwich ELISA) for detection and quantitation of human H-FABP in biochemical samples.

Chapter 5 describes the qualitative assessment of AMI through measurements of plasma H-FABP levels, while in Chapter 6 the emphasis is put on the quantitative assessment of total cardiac tissue damage as a result of AMI. In both Chapters 5 and 6 the results were compared with values obtained from measurements of myoglobin and of commonly used enzymatic markers like the cardiospecific enzymes creatine kinase MB (CK-MB) and alpha-hydroxybutyrate dehydrogenase $(\alpha-\mathrm{HBDH})$. Results of both chapters showed that H-FABP plasma levels can indeed be used for both qualitative and quantitative assessment of AMI.

The validity of a consecutive hypothesis, namely that the fast appearance of $\mathrm{H}$ FABP in the circulation upon AMI should be reflected by a depletion of H-FABP from cardiac tissue, was tested by performing macroscopic enzyme-histochemical and microscopic histochemical and immunohistochemical analyses of human myocardial tissue sections that included areas that had suffered from ischaemia and/or infarction (Chapter 7). Results showed that microscopic evaluation of cardiac tissue sections, immunostained with antibodies against human H-FABP, can reveal myocardial infarctions with a post-infarction interval of less than four hours.

The results of the various investigations in this thesis are compared, discussed, and summarized in Chapter 8.

From the investigations presented in this thesis the following major conclusions can be drawn:

1. The plasma concentration of heart-type FABP is a useful parameter for the early assessment or exclusion of acute myocardial infarction in man.

2. Heart-type FABP released from the heart after acute myocardial infarction is quantitatively recovered in plasma and is a useful biochemical plasma marker for the estimation of myocardial infarct size in man.

3. Heart-type FABP immunostaining may detect very recent ischemia/infarction in human myocardium and can be applied in routine autopsy pathology. 


\section{SAMENVATTING}

Het verschijnen van cytoplasmatische bestanddelen van hartspiercellen (bijv. eiwitten) in de bloedbaan is een typisch gevolg van een acuut myocardiaal infarct (AMI). Door ernstige beschadiging van de celwand is de doorlaatbaarheid van dit membraan sterk verhoogd hetgeen resulteert in de afgifte van intracellulaire bestanddelen, waaronder eiwitten, aan de interstitiële ruimte (weefselvocht). Vanuit de interstitiële ruimte komen deze eiwitten terecht in de bloedbaan, hetzij door een direct transport door de endotheliale lijst, of indirect via het lymiatisch afvoersysteem. De hoeveelheid (of enzymatische activiteit van) myocardiale cytoplasmatische eiwitten in het plasma kan gebruikt worden om zowel het optreden als ook de omvang van een AMI vast te stellen. Dierexperimenteel onderzoek heeft aangetoond dat tot de cytoplasmatische eiwitten die na AMI in de bloedbaan verschijnen ook het myocardiaal vetzuurbindend eiwit behoort (heart-type fatty acid-binding protein, H-FABP).

De studies, die in dit proefschrift beschreven zijn, werden opgezet om de hypothese te verifiëren dat het gehalte aan H-FABP in bloedplasma gebruikt kan worden voor zowel de kwalitatieve als de kuantitatieve bepaling van een AMI bij patienten met klinische aanwijzingen voor deze aandoening. Daartoe werd het $\mathrm{H}$ FABP gehalte in plasma vergeleken met dat van verschillende cytoplasmatische eiwitten en enzymen die momenteel voor dit doel al gebruikt worden.

In Hoofdstuk 1 wordt eerst een algemene inleiding gegeven over het transport en metabolisme van vetten in het hart, en de rol die het H-FABP hierbij waarschijnlijk speelt. Ook worden een aantal basale redenen besproken waarom ischemie schade aan het hart veroorzaakt. Tenslotte worden de hoofdlijnen van het proefschrift uiteengezet. In Hoofdstuk 2 wordt de bepaling van H-FABP in bloedplasma beschreven. Vanwege de aanwezigheid in bloedplasma vane een relatief grote hoeveelheid albumine, een eiwit dat ook vetzuur kan binden, is het niet mogelijk de hoeveelheid H-FABP in plasma direct te meten door gebruik te maken van de functionele eigenschap van H-FABP. Voor een aantal andere kwantitatieve bepalingsmethoden geldt verder dat het H-FABP eerst uit plasma gezuiverd zou moeten worden, hetgeen onnauwkeurigheden tot gevolg kan hebben. Om bovenstaande redenen werd besloten een kwantitatieve immunochemische bepalingsmethode (een zogenaamde kwantitatieve immunoassay) te ontwikkelen, waarmee vervolgens het verloop van het $\mathrm{H}$-FABP gehalte in plasma kan worden gevolgd. Het feit dat er meerdere (weefsel-)specifieke FABP typen bestaan zette ons ertoe aan te proberen om oligo-peptiden te synthetiseren, corresponderend met verschillende antigene delen van het menselijk H-FABP molecuul. Deze synthetische peptiden werden daarna gebruikt om antilichamen op te wekken die specifiek gericht zijn tegen het menselijk H-FABP. Het gebruik van deze antilichamen in de immunoassay zou de specificiteit van deze methode kunnen verhogen. Naast een klassieke beschrijving van alle materialen en methoden die gebruikt werden voor het uitvoeren van het merendeel van de experimenten, worden in Hoofdstuk 2 ook de synthese van deze oligo-peptiden en het opwekken van antilichamen, specifiek gericht tegen het menselijk H-FABP, beschreven.

Hoofdstuk 3 bevat een gedetailleerde beschrijving van immunoassays in het algemeen, waarbij de nadruk is gelegd op de ontwikkeling en validering van een 
kwantitatieve immunoassay (sandwich ELISA) voor het meten van hoeveelheden H-FABP in menselijk bloedplasma in het bijzonder. In Hoofdstuk 4 wordt beschreven dat de immunochemische experimenten, waarbij gepoogd werd om antilichamen tegen de synthetische peptiden van het menselijk H-FABP molecuul te gebruiken, niet tot het gewenste resultaat hebben geleid. Daarentegen bleken antilichamen tegen het volledig H-FABP molecuul zeer bruikbaar te zijn om een betrouwbare en gevoelige bepalingsmethode op te zetten.

Hoofdstuk 5 handelt over de kwalitatieve aantoning van een AMI door meting van de hoeveelheden H-FABP in plasma, terwijl in Hoofdstuk 6 de nadruk wordt gelegd op de kwantitatieve bepaling van de totale hoeveelheid weefselschade ten gevolge van het AMI. In beide Hoofdstukken worden de resultaten vergeleken met uitkomsten van metingen in plasma van myoglobine en andere gebruikelijke parameters zoals de hartspecifieke enzymen creatine kinase $\mathrm{MB}$ (CK-MB) en alphahydroxybutyraat dehydrogenase $(\alpha-\mathrm{HBDH})$. De resultaten in beide hoofdstukken tonen aan dat de hoeveelheden H-FABP in plasma inderdaad gebruikt kunnen worden voor zowel een kwalitatieve als een kwantitatieve bepaling van een AMI.

In Hoofdstuk 7 is de geldigheid van een daaruit voortvloeiende hypothese getest, namelijk dat het snelle verschijnen van $\mathrm{H}$-FABP in de bloedbaan na een AMI gecorreleerd zou moeten zijn aan het verdwijnen van $H$-FABP uit hartweefsel. Hiertoe werden macroscopische enzym-histochemische en microscopische histochemische en immunohistochemische experimenten uitgevoerd op coupes van menselijk hartspierweefsel waarin zich gebieden bevonden die ischemie en/of een infarct hadden ondergaan. De resultaten van deze experimenten tonen aan dat microscopische beoordeling van hartweefsel coupes, na een immunokleuring met antilichamen tegen het menselijk H-FABP, myocardiale infarcten die jonger zijn dan vier uur - gerekend vanaf het moment van het optreden van de eerste klinische tekenen van AMI - aan het licht kan brengen.

De resultaten van de verschillende studies in dit proefschrift worden vergeleken, besproken en samengevat Hoofdstuk 8.

De belangrijkste conclusies die uit de resultaten van het onderzoek, zoals beschreven in dit proefschrift, getrokken kunnen worden zijn:

1. De plasma concentratie van het hart-type FABP is goed bruikbaar om bij de mens de aanwezigheid van een acuut myocardinfarct te bevestigen dan wel uit te sluiten.

2. Al het hart-type FABP dat na een acuut myocardinfarct bij de mens vrijkomt uit het hart wordt teruggevonden in het plasma en kan daarom gebruikt worden als biochemische plasma merker voor de schatting van de grootte van het myocardinfarct.

3. Immunohistochemische aankleuring van het hart-type FABP kan in de pathologie routinematig gebruikt worden om zeer recente ischemie of infarcering van het menselijk myocard aan te tonen. 


\section{PAPERS}

1. Kleine AH, Glatz ]FC, van Nieuwenhoven FA, Vallinga MI], Salden MHL, Bosman FT, Boersma WJA, Zegers. ND and van der Vusse GJ. Type-specific immunodetection of human heurt fatty acidbinding protein with polyclonal anti-peptide antibodies. Mol Cell Biochem 98: 41-48, 1990.

2. Van Nieuwenhoven FA Vork MM. Surtel DAM, Kieine AH. van der Vusse GJ. Glatz JPC. Highyield two-step chromatographic procedure for purification of fatty acid-binding protein from human heart. J Chromatogr 570: 173-179, 1991.

3. Kleine AH, Glatz JFC, van Nieuwenhoven FA, and van der Vusse G). Release of heart fatty acid. binding protein into plasma after acute myocardial infarction in man. Mol Cell Biochem 116: 155 162, 1992.

4. Kleine AH, Glatz JFC, Havenith MG, van Nieuwenhoven FA, van der Vusse G], Bosman FT Immunohistochemical detection of very recent myocardial iniarctions in man with antibodies against heart type fatty acid-binding protein. Cardiovasc Pathol' 2: 63-69, 1993.

5. Glatz JFC, Kleine AH, van Nieuwenhoven FA, van Dieijern-Visser MP, Hermens WT and van der Vusse G]. Fatty acid-binding protein and myoglobin as plasma markers for the early assessment of acute myocardial infarction in man. Tijdschr NVKC 18: xxx-xxx, 1993.

6. Van Nieuwenhoven FA, Kleine AH, Keizer HA, van Dieijen MP, van der Vusse GJ, Glatz JFC. Release of myoglobin and fatty acid-binding protein from human cardiac and skeletal muscles upon tissue damage Submitted.

7. Hermens WTh, van Dieijen-Visser MP, Kleine AH, van der Wieken LR and Simoons ML. Identical estimates of myocardial infarct size from myoglobin and from enzymes in plasma. Submitted.

8. Glatz JFC, Kleine AH, van Nieuwenhoven FA, Hermens WT, van Dieijen-Visser MP and van der Vusse G]. Fatty acid-binding protein as plasma marker for the estimation of myocardial infarct size in man. Submitted.

\section{ABSTRACTS}

1. Kleine AH, Glatz JFC, van der Vusse GJ, Bosman FT, Boersma WJA, Salden MHL., van Nieuwenhoven FA and Vallinga MIJ. Application of synthetic peptides for the generation of antibodies with predefined specificity against human heart FABP. Abstract: $1^{\text {st }}$ Int. Workshop on Fatty Acid-Binding Proteins, Maastricht, p. 48, 1989.

2. Kleine $\mathbf{A H}$, van Nieuwerhoven FA, van der Vusse GJ and Glatz JFC. Human heart fatty acidbinding protein: a possible plasma marker for acute myocardial infarction. Abstract; $31^{\text {" }}$ Int. Conference on the Biochemistry of Lipids, Münster, p. 72, 1990.

3. Kleine AH, Glatz IFC, van Nieuwenhoven FA, van der Vusse GJ. Release of heart fatty acidbinding protein into human plasma after acute myocardial infarction. Eur I Physiol (Pflugers Arch) 418: R 148, 1991.

4. Van Nieuwenhoven FA, Surtel DAM, Kleine AH, van der Vusse G], Glatz JFC. A new method for the purification of fatty acid-binding protein from human heart. Abstracts $3^{\text {rd }}$ Int. Symposium on Lipid Metabolism in the Normoxic and Ischemic Heart, Rotterdam 1991: 6.

5. Kleine AH, Glatz JFC, van Nieuwenhoven FA, van der Vusse GJ. Release of heart fatty acidbinding protein ( $\mathrm{H}-\mathrm{FABP}_{c}$ ) in man during acute myocardial infarction: a novel, immunologic techrique to monitor ischemic damage. Abstracts $3^{\text {rd }}$ Int. Symposium on lipid Metabolism in the Normoxic and lschemic Heart, Rotterdam: 8, 1991.

6. Kleine AH, Glatz JFC, van Nieuwenhoven FA, van der Vusse GJ. Release of fatty acid-binding protein from ischaemic myocardium into plasma in man. I Mol Cell Cardiol 23: S 97, 1991.

7. Glatz JFC, Vork MM, Kleine AH, van der Vusse GJ. Heart-type fatty acid-binding protein: myocardial content and tissue distribution, and release upon cellular injury. Abstracts Monod Conference on Molecular aspects of Lipid Flow in the Cell, Roscoff (France): 27, 1991.

8. Kleine AH, Glatz JFC, van Nieuwenhoven FA, Willems GM, Hermens WTh, van Dieijen-Visser MP, van der Vusse GJ. Relation between the release of heart fatty acid-binding protein and of myoglobin into plasma after myocardial infarction in man. Eur J Physiol (Pflügers Arch) 420: R 109, 1992. 
9. Kleine AH, Glatz JFC, Havenith MG, van Nieuwenhoven FA, van der Vusse GJ, Bosman FT. Fatty acid-binding protein as an immunohistochemical marker for the detection of very recent myocardial infarctions in man. Histochem / 24: 573, 1992.

10. Glatz JFC, Vork MM, Kleine AH, van Nieuwenhoven F, Snoeckx L.HEH and van der Vusse GJ. Transmembrane and intracellular transport of fatty acids in the heart. Abstracts International Workshop on Energy Production in Hypertrophied hearts, Beaune (France), 1992.

11. Van Nieuwenhoven FA, Kleine AH, Keizer HA, van Dieijen MP, Van Der Vusse GJ and Glatz JFC. Comparison of myoglobin and fatty acid-binding protein as plasma markers for muscle damage in man. Eur J Physiol (Pfiugers Arch) 421: R 40, 1992. 


\section{CURRICULUM VITAE}

$1954 \quad$ Geboren te Amstenrade (L) op 4 februari

1966-1973 Gymnasium B, Grotius College, Heerlen (L)

1973-1980 Studie Biologie, Rijksuniversiteit Utrecht

1981 Medewerker Vakgroep Moleculaire Celbiologie, Rijksuniversiteit Utrecht

1981-1982 Wetenschappelijk medewerker, Vakgroep Experimentele Embryologie,

1982

1982-1987 Rijksuniversiteit Utrecht

1987-1991

Wetenschappelijk medewerker, Hubrecht Laboratorium, Utrecht Fulltime huisman, Hoensbroek (L)

Toegevoegd onderzueker, Vakgroep Fysiologie, Rijksuniversiteit Limburg, Maastricht

1993- Post-doc medewerker, Cardiovascular Research Institute Maastricht

(CARIM), Maastricht 
